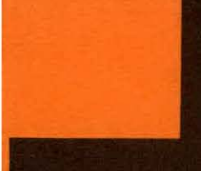

DR\#0459-6 DOE/MC/22012-2542 (DE88001040)

\title{
Gasification of char in a membrane filter: Final report
}

Hess, M.; Di Bella, C.A.W.

Aug 1987

KOH Systems, Inc., Rockville, MD (USA)

Reproduced and Distributed by:

U.S. DEPARTMENT OF ENERGY

Office of Scientific and Technical Information P.O. Box 62

Oak Ridge, TN 37831

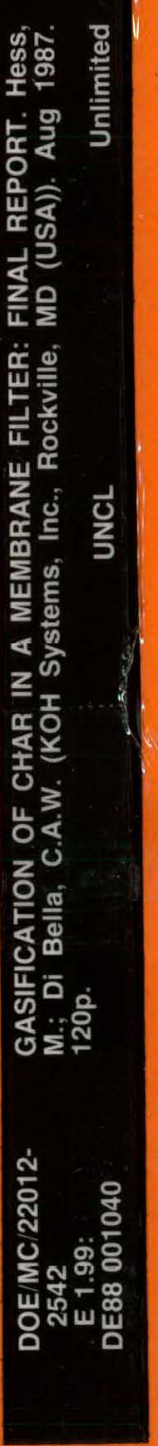




\section{DISCLAIMER}

This report was prepared as an account of work sponsored by an agency of the United States Government. Neither the United States Government nor any agency Thereof, nor any of their employees, makes any warranty, express or implied, or assumes any legal liability or responsibility for the accuracy, completeness, or usefulness of any information, apparatus, product, or process disclosed, or represents that its use would not infringe privately owned rights. Reference herein to any specific commercial product, process, or service by trade name, trademark, manufacturer, or otherwise does not necessarily constitute or imply its endorsement, recommendation, or favoring by the United States Government or any agency thereof. The views and opinions of authors expressed herein do not necessarily state or reflect those of the United States Government or any agency thereof. 


\section{DISCLAIMER}

Portions of this document may be illegible in electronic image products. Images are produced from the best available original document. 


\section{DISCLAIMER}

This report was prepared as an account of work sponsored by an agency of the United States Government. Neither the United States Government nor any agency thereof, nor any of their employees, makes any warranty, express or implied, or assumes any legal liability or responsibility for the accuracy, completeness, or usefulness of any information, apparatus, product, or process disclosed, or represents that its use would not infringe privately owned rights. Keference herein to any specific commercial product, process, or service by trade name, trademark, manufacturer, or otherwise does not necessarily constitute or imply its endorsement, recommendation, or favoring by the United States Government or any agency thereof. The views and opinions of authors expressed herein do not necessarily state or reflect those of the United States Government or any agency thereof.

This report has been reproduced directly from the best available copy.

Available from the National Technical Information Service, U. S. Department of Commerce, Springfield, Virginia 22161.

\section{Price: Printed Copy A06}

Microfiche A01

Codes are used for pricing all publications. The code is determined by the number of pages in the publication. Information pertaining to the pricing codes can be found in the current issues of the following puhlications, which are generally available in most libraries: Energy Research Abstracts (ERA); Government Reports Announcements and Index (GRA and I); Scientific and Technical Abstract Reports (STAR); and publication NTIS-PR-360 available from NTIS at the above address. 
$\mathrm{DOE} / \mathrm{MC} / 22012-2542$

(DE88001040)

Distribution Category UC-109

\title{
Gasification of Char in a Membrane Filter
}

\author{
Final Report
}

\author{
M. Hess \\ C.A.W. Di Bella
}

Work Performed Under Contract No.: DE-AC21-85MC22012

\author{
For \\ U.S. Department of Energy \\ Office of Fossil Energy \\ Morgantown Energy Technology Center \\ P.O. Box 880 \\ Morgantown, West Virginia 26507-0800 \\ By \\ $\mathrm{KOH}$ Systems, Inc. \\ 164 Rollins Avenue \\ Rockville, Maryland 20852
}

August 1987 


\section{THIS PAGE}

\section{WAS INTENTIONALLY \\ $\therefore$ LEFT BLANK}




\section{ACRNOWLEDGEMENT}

The authors wish to thank Dr. Norman Holcombe, the METC Technical Officer for this task, for his effective and timely direction, comments and review. They also thank Mr. Randall J. Dellefield and Dr. A. W. Gessner of DOE for helpful discussion ard guidance, Dr. Ghate of DOE and Dr. S. Ratta and Mr. Dale R. Schmidt of RRW Energy Systems Inc. for supplying valuable information and data, and Ms. Elaine Passini of EG\&G for assistance in the literature search. 
I. INTRODUCTION 1

II. LITERATURE SURVEY

2.1 Noncatalytic Gasification 2

2.2 Catalyzed Gasification of Char 28

2.3 Diffusional Resistances 53

2.4 Char Characteristics and Reactivities . 55

2.5 Comments on Literature Survey 58

2.6 Summary/Evaluation of Literature Data 60

III. HYPOTHESIZED METHODS

3.1 In-P] ace Gasification in thc Filter 64

3.2 Increased Char Residence Time in Filter 68

3.3 Removal of Char from Filter 68

3.4 Increase in Pressure of Filter 68

IV. EVALUATION OF HYPOTHESIZED METHODS

4.1 In-Place Gasification in Membrane Filter 69

4.2 Increased Char Residence Time In Filter 105

4.3 Removal of Char from Filter 106

V. CONCLUSIONS 108

KEFERENCES $\quad 112$ 


\section{INTRODUCTION}

This report deals with the feasibility of reducing the amount of char on a barrier filter by in-place gasification. A large volume of work has been done on the gasification of char, and our first task is to sort out that which is most relevant and to apply it to the problem posed to us.

A meeting was held at Morgantown on April 1,1987 to set guidelines for this task. Present at the meeting were Dr. Norman Holcombe, Mr. Randall Dellefield and Dr. A. W. Gessner representing DOE, and Drs. Carlos Di Bella and Martin Hess representing KOH Systems, Inc. At this meeting, DOE personnel gave overall guidelines as to project priorities and provided helpful information on sources of information for the project. A discussion of the principal gasification methods led to the conclusion that the gasification of filter char from fixed bed and fluidized bed gasifiers was of greatest interest. Modern pressurized entrained gasifiers generally yield nearly complete gasification of the carbon, and gasification of any residual char was considered of little interest. 


\section{LITERATURE SURVEY}

Char can-be gasified by reaction with carbon dioxide, steam or hydrogen. The reaction products and the rates at which theg are produced depend on the temperature, pressure, and composition of the gas phase, type of reactor, presence or absence of catalysts, and, in addition, on the properties of the original coal and on the conditions under which it was converted into char. Compared to the very rapid pyrolysis step, the gasification of char on a filter requires substantial time under conditions that favor the gasification reactions. In going through the literature, three categories of information were of greatest interest:

1. The origin, characteristics and properties of the char.

2. The conditions under which the char was gasified and the rates and extents of the gasification reactions.

3. Any interpretation or mathematical modeliing of the experimental results.

\subsection{NONCATALYTIC GASIFICATION}

The rate of gasification is usually expressed as the weight of char gasified/original weight per unit time, which has units of reciprocal time, e.g. min ${ }^{-1}$, the units used throughout this report. 


\subsubsection{Carbon-Carbon Dioxide Reaction}

Von Fredersdorff (1955) concluded that his experimental data on the $\mathrm{C}-\mathrm{CO}_{2}$ reaction

$$
\mathrm{C}+\mathrm{CO}_{2}--\rightarrow 2 \mathrm{CO}
$$

were well correlated by the Langmuir-Hinshelwood rate expression:

$$
r=k b \mathrm{P}_{\mathrm{CO}_{2}} /\left(1+a \mathrm{p}_{\mathrm{CO}}+\mathrm{b} \mathrm{p}_{\mathrm{CO}_{2}}\right)
$$

which may be recast into the form:

$$
r=k /\left(1 /\left(b \mathrm{p}_{\mathrm{CO}_{2}}\right)+a \mathrm{p}_{\mathrm{CO}} /\left(\mathrm{b}_{\mathrm{CO}_{2}}\right)+1\right\}
$$

where $r$ is the reaction rate in $\mathrm{min}^{-1}, k$ is the net kinetic rate constant in $\min ^{-1}$ atm $^{-1}$, a is the equilibrium constant for the adsorption of $\mathrm{CO}$ and $\mathrm{b}$ is the equilibrium constant for the adsorption of $\mathrm{CO}_{2}$. Von Fredersdorff derived this rate equation by four different mechanisms to demonstrate that the reaction mechanism is not uniquely defined by the rate equation.

Ergun (1962) studied both the carbon-carbon dioxide and the carbon-steam reaction. For the $\mathrm{C}-\mathrm{CO}_{2}$ reaction he proposed the following mechanism involving free sites, $C_{f}$, and occupied sites, $C_{0}$, possessing an oxygen atom on the carbon surface. The first step in his proposed mechanism involves the reaction of gaseous $\mathrm{CO}_{2}$ with a free site to yield an occupied site and gaseous co:

$$
\mathrm{C}_{\mathrm{f}}+\mathrm{CO}_{2} \Leftrightarrow \mathrm{C}_{\mathrm{o}}+\mathrm{CO} \quad[\mathrm{R} \times \mathrm{Cn} \cdot 1]
$$

In the second step, carbon from the solid phase is transferred to the gas as $\mathrm{CO}$ :

$$
\mathrm{C}_{\mathrm{O}}-\rightarrow \mathrm{CO}+\mathrm{C}_{\mathrm{f}} \quad[\mathrm{R} \times \mathrm{n} \cdot 2]
$$

The sum of reactions 1 and 2 gield the overall $\mathrm{C}-\mathrm{CO}_{2}$ reaction, the 
free site on the right hand site of equation (2) merely being used by Ergun to indicate that the total number of reaction sites (sum of free and occupied sites) is assumed to remain constant.

The co desorption was postulated by Ergun to be the ratecontroling step, which led him to derive the rate equation:

$$
\tau=\mathrm{k} /\left\{1+\mathrm{p}_{\mathrm{CO}} / \mathrm{R}_{1} \mathrm{p}_{\mathrm{CO}_{2}}\right\}
$$

where the rate constant $k$ depends on the temperature and on the characteristics of the solid carbon phase, and $R_{1}$ is the equilibrlum constant for the oxpgen exchange reaction [Rxn. 1]. Comparison of equations ( $1^{\prime}$ ) and (4) shows that equation ( ${ }^{\prime}$ ) simplifies to equation (4) when the term $1 /\left(\mathrm{b} \mathrm{p}_{\mathrm{CO}_{2}}\right)$ can be neglected, i.e. when $1 /\left(\mathrm{b} \mathrm{P}_{\mathrm{CO}_{2}}\right) \ll 1$.

Ratta and Keairns (1981) determined the reaction rate of coke breeze with $\mathrm{CO}_{2}$ and found good agreement with Ergun's model. They determined the following constants:

$$
\begin{aligned}
& k=0.55 \times 10^{10} \exp [-69000 / R T] \\
& R_{1}=5.86 \times 10^{3} \exp [-27000 / R T]
\end{aligned}
$$

where the activation energies (i.e. 69000 and 27000) are expressed in calories/mole, the temperature in kelvins and the gas constant $R=1.987 \mathrm{cal}^{\mathrm{mol}} \mathrm{e}^{-1} \mathrm{kelvin}^{-1}$. The kinetic constant $\mathrm{k}$ has units of min ${ }^{-1}$ and the equilibrium constant $\mathbb{R}_{1}$ is dimensionless.

Substitution of (5) and (6) into equation (4) pields the results Iisted in Table 1 for the rate of $\mathrm{CO}_{2}$ gasification of coke breeze, a very unreactive material. 


\section{$\underline{T A B L E} \underline{1}$}

Gasification rate of coke breeze in $\underline{\mathrm{CO}}_{2}$

\begin{tabular}{|c|c|c|c|c|c|}
\hline Temp., ${ }^{\circ} \mathrm{C}-->$ & 800 & 900 & 1000 & 1100 & 1200 \\
\hline${ }^{\mathrm{P}_{\mathrm{CO}} / \mathrm{P}_{\mathrm{CO}}}$ & \multicolumn{5}{|c|}{ Rate, min $^{-1}$} \\
\hline $0.0^{2}$ & $5.1 \times 10^{-5}$ & $8.0 \times 10^{-4}$ & 0.0082 & 0.059 & 0.330 \\
\hline 0.2 & $4.4 \times 10^{-6}$ & $1.7 \times 10^{-4}$ & 0.0033 & 0.036 & 0.246 \\
\hline 0.4 & $2.3 \times 10^{-6}$ & $9.8 \times 10^{-5}$ & 0.0021 & 0.026 & 0.196 \\
\hline 0.6 & $1.6 \times 10^{-6}$ & $6.8 \times 10^{-5}$ & 0.0015 & 0.020 & 0.163 \\
\hline 0.8 & $1.2 \times 10^{-6}$ & $5.2 \times 10^{-5}$ & 0.0012 & 0.016 & 0.140 \\
\hline
\end{tabular}

Katta and Keairns ran their experiments at temperatures from $927^{\circ} \mathrm{C}$ to $1050^{\circ} \mathrm{C}$. Rates outside this range are extrapolations. For this particular material, coke breeze, which is rather unreactive, gasification in pure carbon dioxide would require about 3 minutes at $1200^{\circ} \mathrm{C}, 17$ minutes at $1100^{\circ} \mathrm{C}$, about 2 hours at $1000^{\circ} \mathrm{C}$ and 21 hours at $900^{\circ} \mathrm{C}$. However, the rate decreases with increasing carbon monoxide concentration.

Johnson (1982) studied the gasification rate of a high volatile A bituminous coal char prepared by devolatilizing the raw coal in nitrogen at the same temperature used in the subsequent gasification. The char was gasified in $\mathrm{CO}_{-} \mathrm{CO}_{2}$ mixtures at 2-35 atm and $850-1000^{\circ} \mathrm{C}$. Johnson correlated the results by a LangmuirHinshelwood model [equation ( 1 )] with the following parameters:

$$
\begin{aligned}
& k_{c}=k b=3.56 \times 10^{3} \exp [-28430 / R T] \\
& a=0.15 \exp [6400 / R T]
\end{aligned}
$$




$$
b=1.04 \times 10^{-7} \exp [36500 / \mathrm{RT}]
$$

where $k_{c}$ is in min $\operatorname{mot}^{-1}$, a and $b$ are in atm ${ }^{-1}$, the activation energies are in calories, and temperature is in kelvins.

Substitution of these results into equation (1) for a pure $\mathrm{CO}_{2}$ atmosphere yields the results listed in Table 2 .

\section{TABLE 2}

Gasification rate of high-volatile A bituminous coal char Temp., ${ }^{\circ} \mathrm{C}-->$ 800

900
Rate, min $^{-1}$

$\begin{array}{lrrrrr}1 \mathrm{~atm} & 0.0016 & 0.011 & 0.040 & 0.101 & 0.213 \\ 10 \mathrm{~atm} & .0021 & .025 & .166 & .650 & 1.73 \\ 20 \mathrm{~atm} & .0021 & .027 & .200 & .932 & 2.86\end{array}$

As pointed out by Johnson, the Langmuir-Hinshelwood kinetic equation (1) predicts that, as the pressure increases, the rate becomes independent of pressure. Fuchs and Yavorsky (1975) found that at $750^{\circ} \mathrm{C}$ and $800^{\circ} \mathrm{C}$, total pressure had no effect on the rate of $\mathrm{CO}_{2}$ gasification of bituminous coal chars in the 18-35 atm range. Johnson states that total pressure has little effect on the reaction rate above 10 atm. However, on the basis of the above tabulation, it appears that the pressure at which the pressure effect vanishes increases with temperature.

Comparitun of the data in Tables 1 and 2 indicales Lhal Lhy char from the bituminous coal reacts with $\mathrm{CO}_{2}$ about 5 times faster: than does coke breeze. 
As pointed out by Mentser and Ergun (1973), carbon monoxide slows the reaction by the reverse oxygen exchange reaction [equation (2), reverse reaction] rather than by chemisorption. As the co concentration increases, the equilibrium shifts to the left and the concentration of occupied sites decreases. The lower $C_{0}$ concentration in turn slows the rate of the controlling step [equation (3)].

Dutta et al.(1975) observed gasification rates in carbon dioxide of chars derived from high volatile bituminous coals at 1 atm and $850-1080^{\circ} \mathrm{C}$, and derived the following equations for the initial rates in pure $\mathrm{CO}_{2}$ at 1 atm:

Pittsburgh seam: rate $=(0.61 \pm .13) \times 10^{9} \exp [-59260 / \mathrm{RT}]$

Illinois seam: $\quad$ rate $=(1.21 \pm .25) \times 10^{9} \mathrm{exp}[-59,260 / \mathrm{RT}]$

These equations yield the rates shown in Table 3 :

$\underline{T A B L E} \underline{3}$

Gasification rate of high-volatile A bituminous coal char $\underline{\text { in }}$ pure $\mathrm{CO}_{2}$

Temp., deg. C $-->800 \quad 900 \quad 1000 \quad 1100 \quad 1200$

\begin{tabular}{|c|c|c|c|c|c|}
\hline \multicolumn{6}{|c|}{ Rate, $\underline{m i n}^{-1}$ at $\underline{1}$ atm } \\
\hline Pittsburgh & $5.42 \times 10^{-4}$ & 0.0058 & 0.042 & 0.233 & 1.02 \\
\hline IIInois & 0.0011 & 0.0115 & 0.084 & 0.462 & 2.01 \\
\hline
\end{tabular}

Taylor and Bowen (1976) studied the gasification of subbituminous coal chars in pure $\mathrm{CO}_{2}$ at 1 atm and at temperatures from 600 to $790^{\circ} \mathrm{C}$. The specific gasification rates were correlated by the expression: 


$$
\text { rate }=4.2 \times 10^{7} \exp [-45000 / R T]
$$

The rates calculated by this equation as a function of temperature (including extrapolations up to $1000^{\circ} \mathrm{C}$ are shown in Table 4:

\section{$\underline{T A B L E} \underline{4}$}

\section{Gasification rate of subbituminous coal char}

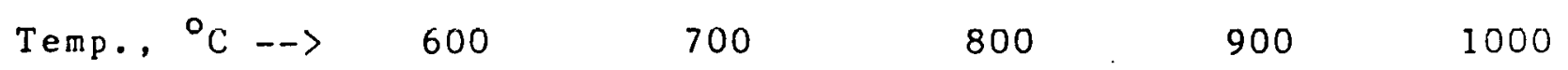

\section{Pressure}

$$
\text { Rate, } \text { min }^{-1}
$$
1 atm.
0.00024
0.0034
0.030
0.179
0.812

Comparison with the rates for coke breeze and for bituminous coal char ohows the much grcatcr reactivity of the subbituminous coal char, which is in line with the observation that the reactivity of coals (and of their chars) decreases with increasing rank. Table 5, taken from Johnson, shows the effect of rank (and other factors) on the initial gasification rates at $900^{\circ} \mathrm{C}$ :

\section{TABLE $\underline{5}$}

Comparison of Gasification rates in 1 atm $\underline{\mathrm{CO}}_{2}$ at $900^{\circ} \mathrm{C}$

\section{Carbon type}

Subbituminous coal char

High-volatile bituminous coal char (Illinois)

High-volatile bituminous coal char (Pittsburgh)

Activated carbon

Anthracite

High-volatile bituminous coal char (Pittsburgh)

Coke

Activated graphite, carbon black

Coke

$$
\operatorname{Rate}\left(\min ^{-1}\right)
$$

0.23

0.012

0.011

0.009

0.007

0.006

0.003

0.0009

0.0006 
Koenig et al. (1985) made a detailed study of the $\mathrm{C}-\mathrm{CO}_{2}$ reaction using Saran char and found verg small deviations from the one site reaction mechanism compatible with the LangmuirHinshelwood kinetics. They concluded that the deviations, though small, were statistically significant and that a two-site mechanism was necessary to explain the data. However, because the deviations are small enough, thelr equations constitute a minor refinement over the Langmul-Hinshelwood equation, which is adequate for most practical applications.

The Department of Chemical Engineering at Vanderbilt Universitg (1984) studied the changes in the particle structure of coal as it underwent the carbon/carbon dioxide reaction. Char was produced by heating wyodak coal at $25^{\circ} \mathrm{C} / \mathrm{min}$ to the reaction temperatures of $800,900,1000$ and $1100^{\circ} \mathrm{C}$, and the changes in effective diffusivity and surface area were followed through the devolatilization and reaction steps. The surface areas exhibited a maximum in all cases when plotted against conversion. The global maximum occurred at $1000^{\circ} \mathrm{C}$. The times required to attain $75 \%$ conversion of Wyodak coal char varied as follows with temperature:

\begin{tabular}{|c|c|c|c|c|c|c|c|}
\hline Tcmperatule, ${ }^{\circ} \mathrm{C}$ & 800 & 850 & 900 & 950 & 1000 & 1050 & 1100 \\
\hline ime, min & 49 & 30 & 23 & 10.6 & 5.7 & 4.0 & 1.1 \\
\hline
\end{tabular}

Rate data were obtained over the $800-1000^{\circ} \mathrm{C}$ range for chars produced from the following five coals: 


\section{Proximate analgsis, \%}

Coal

Wilcox lignite (Texas)

Wyodak subbituminous (Wyoming)

Cimmeron bituminous (Rentucky)

Illinois \#6 bituminous

Pittsburgh bituminous
Volatiles

54.7

49.8

50.2

38.8

37.5
Fixed Carbon

Ash

31.3

14.0

43.4

6.8

43.3

6.4

48.9

5.8

56.7

The order of reactivity was:

Wilcox > Wyodak > Cimmeron > Iilinois > Pittsburgh

The maximum rates observed at $1000^{\circ} \mathrm{C}$ were as follows:

Coal

Wilcox Wyodak Cimmeron Illinois Pittsburgh

Max. rate, $\min ^{-1}$ .20

.15

.026

.030 .010

All coal chars exhibited a maximum reaction rate as a function of conversion. The emplical models of Dutta et al. (1977), Kasaoka et al. (1982) and Simons (1979)-Chornet (1979) and the theoretical model of Bhatia and Perlmutter (1981) for gas-solid reactions were evaluated for all coal chars except for Wyodak. Rasaoka's model gave the best least squares fit for all four coal chars, followed by models of Simons-Chornet and Bhatia and Perlmutter. The Dutta-Wen model was equal to the Bhatia-Perlmutter model for Illinois coal char, but worse for the other coals.

When applied to the $\mathrm{C}-\mathrm{CO}_{2}$ reaction the Bhatia-Perlmuter rate model is: 


$$
d X / d t=C_{\mathrm{CO}_{2}} S_{0}(1-X)[1-p s i \cdot 1 n(1-X)]^{1 / 2} /\left\{1-e p s i l o n_{0}\right\}
$$

and for this model the specific surface area is related to conversion by:

$$
S=S_{0}(1-X)[1-\operatorname{psi\cdot ln}(1-X)]^{1 / 2}
$$

In the above equations, $X$ is the conversion, $t$ is the time, epsilon is the porosity, $S$ is the reaction surface area per unit volume, and psi is the structural parameter defined below, one of two parameters in the Bhatia-Perlmutter model, The subscripto denotes an initial condition $(t=0)$.

The structural parameter, psi, is defined as

$$
\text { psi }=4 \text { pi } L_{0}(1-\text { epsilono }) / S_{o}^{2}
$$

where $L_{0}$ is the initial pore length, epsilono is the initial surface area, and $S_{0}$ is the initial surface area per unit volume. The second parameter, tau', is a proportionality constant used in defining the dimensionless time, tau, ( $t a u=t a u^{\prime} \cdot t$ ), where $t$ is actual time and and tau is defined by the equation

$$
\operatorname{tau}^{\prime}=k_{S} C_{n} S_{0} /\left(1-e p s i l o n_{0}\right)
$$

where $k_{s}$ is the rate constant for the surface reaction, and $C_{n}$ is the concentration of a gaseous reactant.

The Bhatia-Perimutter parameters for the $1000^{\circ} \mathrm{C}$ runs made by the Vanderbilt group were:

Coal

Illinois

Pitt.sburgh

Cimmeron (Rentucky)

Wilcox

$$
\text { psi }
$$$$
9.1
$$$$
19.5
$$

14699

30424 tau' $2.837 \times 10^{-3}$

$6.761 \times 10^{-5}$

$7.695 \times 10^{-5}$

$6.084 \times 10^{-6}$ 
In the case of the chars prepared from Wyodak, Illinois and Pittsburgh seam coals, the Bhatia-Perlmutter model yielded physically reasonable values for the structural parameter psi. However, such was not the case with the chars made from Cimmeron bituminous, a highly caking coal, and from Wilcox lignite. The inordinately high values of psi for these two coals has been attributed to either the possibility that the gasification for these two coals may not be in the region of kinetic control and reflects mass transfer limitations, or thạt there may be a catalytic phenomenon not accounted for by this atructural model. Whatever the explanation, the theoretical meaning of the model is lost whenever the parameters merely become fitted constants rather than physical quantities measured independently. For Wyodak coal, the specific surface area was correlated by the following parameters:

$\begin{array}{clcc}\text { Temperature, }{ }^{\circ} \mathrm{C} & \mathrm{S}_{\mathrm{o}} & \mathrm{psi} & \text { valid up to conversion of: } \\ 800 & 225 & 6.99 & 0.5 \\ 900 & 300 & 8.67 & 0.7 \\ 1000 & 301 & 23.6 & 0.6 \\ 1100 & 246 & 11.2 & 0.4\end{array}$

Calculations by the Vanderbilt University authors yielded a Thiele modulus of less than 0.01 up to $1100^{\circ} \mathrm{C}$, indicating no: intraparticle diffusional effect on the reaction rate They: concluded that the carbon dioxide-coal char reaction between 800 and $1100{ }^{\circ} \mathrm{C}$ is chemical rate-controlled. Extensive data on surface: 
areas, pore sizes and diffusion coefficients for the component gases are given in the Vanderbilt University report.

\subsubsection{Carbon-Steam Reaction}

As mentioned above, Ergun (1962) studied both the carboncarbon dioxide and the carbon-steam reaction. For the $\mathrm{C}-\mathrm{H}_{2} \mathrm{O}$ reaction he proposed the following mechanism involving free sites $\left(\mathrm{C}_{\mathrm{f}}\right.$ ) and occupied sites $\left(\mathrm{C}_{\mathrm{O}}\right.$ ) possessing an oxygen atom on the carbon surface. His proposed mechanism is:

$$
\mathrm{C}_{\mathrm{f}}+\mathrm{H}_{2} \mathrm{O} \Leftrightarrow \mathrm{C}_{\mathrm{o}}+\mathrm{H}_{2} \quad \text { OXYGEN EXCHANGE [Rxn. 1] }
$$

The second step involves the transfer of carbon from the solid phase to the gas:

$$
C_{0}-->C O+C_{f} \text { SURFACE OXIDE DECOMPOSITION [Rxn. 2] (17) }
$$

This co desorption is postulated by Ergun to be the ratecontrolling step, which led Ergun to derive the rate equation:

$$
r_{2}=k_{2} /\left\{1+p_{H_{2}} /\left(k_{2} p_{H_{2}}\right)\right\}
$$

where the rate constant $k_{2}$ depends on the temperature and on the characteristics of the solid carbon phase, and $k_{2}$ is the equilibrium constant for the oxygen exchange reaction. As in the case of the $\mathrm{CO}_{2}$ gasification, this is a simplification of the Langmuir-Hinshelwood equation.

Katta and Keairns (1981) determined the reaction rate of coke breeze with $\mathrm{H}_{2} \mathrm{O}$ and found good agreement with Ergun's model. They determined the following constants: 


$$
\begin{aligned}
& k_{2}=4.85 \times 10^{6} \exp [-48200 / R T] \\
& R_{2}=2.25 \times 10^{6} \exp [-42600 / R T]
\end{aligned}
$$

where the activation energies are expressed in calories/mole, the temperature in keloins and the gas constant $R=1.99$ cal mole $e^{-1}$ kelvin ${ }^{-1}$. Substitution of (19) and (20) into equation (18) jields the results for the rate of $\mathrm{CO}_{2}$ gasification of coke breeze displayed in Table 6. Ratta and Reairns ran their experiments at temperatures from $927^{\circ} \mathrm{C}$ to $1050^{\circ} \mathrm{C}$. Rates outside this range are extrapolations. For this particular material, coke breeze, which is rather unreactive, gasification in pure steam would require about 3 minutes at $1200^{\circ} \mathrm{C}, 10$ minutes at $1100^{\circ} \mathrm{C}$, about 38 minutes at $1000^{\circ} \mathrm{C}$ and 190 minutes at $900^{\circ} \mathrm{C}$. The rate decreases with increasing hydrogen concentration as is also shown in Table 6 .

\section{$\underline{\text { TABLE }} \underline{6}$}

\begin{tabular}{|c|c|c|c|c|c|}
\hline Tcmp.,${ }^{\circ} \mathrm{C} \ldots \ldots$ & 800 & 900 & 1000 & 1100 & 1200 \\
\hline $\mathrm{p}_{\mathrm{H}} / \mathrm{p}_{\mathrm{H}, 0}$ & \multicolumn{5}{|c|}{ Rate, $_{\text {min }^{-1}}$} \\
\hline $0.0^{2}$ & $7.6 \times 10^{-4}$ & $5.2 \times 10^{-3}$ & 0.0265 & 0.106 & 0.351 \\
\hline 0.2 & $1.8 \times 10^{-5}$ & $6.2 \times 10^{-4}$ & 0.0095 & 0.070 & 0.297 \\
\hline 0.4 & $9.2 \times 10^{-6}$ & $3.3 \times 10^{-4}$ & 0.0058 & 0.052 & 0.257 \\
\hline 0.6 & $6.2 \times 10^{-6}$ & $2.4 \times 10^{-4}$ & 0.0042 & 0.041 & 0.227 \\
\hline 0.8 & $4.6 \times 10^{-6}$ & $1.7 \times 10^{-4}$ & 0.0033 & 0.034 & 0.203 \\
\hline
\end{tabular}

Gasification rate of coke breeze in $\underline{H}_{2}$ O

Calo et al. (1985) made a study of the transient kinetics of steam gasification of two chars and postulated a somewhat more complex mechanism involving one reversible and three irreversib:le 
reactions:

$$
\begin{array}{rlrl}
\mathrm{C}_{\mathrm{f}}+\mathrm{H}_{2} \mathrm{O} & \Leftrightarrow \mathrm{C}\left(\mathrm{H}_{2} \mathrm{O}\right) & {[\mathrm{R} \times n \cdot 1]} \\
\mathrm{C}\left(\mathrm{H}_{2} \mathrm{O}\right)+\mathrm{C}_{\mathrm{f}} & =\Rightarrow \mathrm{C}(\mathrm{O})+\mathrm{C}\left(\mathrm{H}_{2}\right) & & {[\mathrm{R} \times \mathrm{R} \cdot 2]} \\
\mathrm{C}(\mathrm{O}) & =\Rightarrow \mathrm{CO}+\mathrm{C}_{\mathrm{f}} & & {[\mathrm{R} \times \mathrm{n} \cdot 3]} \\
\mathrm{C}\left(\mathrm{H}_{2}\right) & ==\mathrm{H}_{2}+\mathrm{C}_{\mathrm{f}} & & {[\mathrm{R} \times \mathrm{n} \cdot 4]}
\end{array}
$$

This mechanism was originally proposed by Curran et al. (1968). Calo determined the five rate constants for the above reactions by a least squares minimization search. The chars were derived from coconut char and a Darco lignite. Calo provided temperaturedependent equations for each of these five kinetic constants. For the Darco. Iignite char, Calo reports the following density of active sites $\left(\mathrm{C}_{\mathrm{SO}}\right)$ and rate constants:

$$
\begin{aligned}
& \mathrm{C}_{\text {SO }}=1.6 \times 10^{-6} \mathrm{exp}[+13646 / \mathrm{RT}] \mathrm{sites} / \mathrm{C} \text { atom } \\
& \mathrm{k}_{1}=4.86 \times 10^{9} \mathrm{exp}[-42286 / \mathrm{RT}] \mathrm{min}^{-1} \mathrm{~atm}^{-1} \\
& \mathrm{k}_{-1}=2.65 \times 10^{10} \mathrm{exp}[-51341 / \mathrm{RT}] \mathrm{min}^{-1} \\
& k_{2}=9.32 \times 10^{7} \mathrm{exp}[-33840 / \mathrm{RT}] \mathrm{min}^{-1} \\
& k_{3}=4.21 \times 10^{9} \mathrm{exp}[-42075 / \mathrm{RT}] \mathrm{min}^{-1} \\
& k_{4}=5.07 \times 10^{10} \mathrm{exp}[-47262 / \mathrm{RT}] \mathrm{min}^{-1}
\end{aligned}
$$

Calo shows how these parameters can be used to derive the Langmuir-Hinshelwood steady-state rate equation:

$$
\text { rate }=k^{\prime}{ }_{1} \mathrm{p}_{\mathrm{H}_{2} \mathrm{O}} /\left\{1+\mathrm{K}_{2} \mathrm{p}_{\mathrm{H}_{2} \mathrm{O}}\right\}
$$

where

$$
\begin{aligned}
k_{1}^{\prime} & =k_{1} k_{2} C_{S O}\left(k_{-1}+k_{2}\right) \text {, and, } \\
k_{2} & =k_{1}\left(1+k_{2}\left(1 / k_{3}+1 / k_{4}\right)\right) /\left(k_{-1}+k_{2}\right)
\end{aligned}
$$

Calo's article does not contain sufficient information to calculate the actual reaction rates for Darco lignite char. Calo demonstrates that the Curran mechanism is compatible with his 
data. Other mechanisms may explain the data equally well, as there is an excess of parameters for the available degrees of freedom. Calo also points out that hydrogen has been reported to have a severe inhibiting effect on the rate of reaction, which his data do not test as the amount of hydrogen present was negligible. To account for this effect in the Langmuir-Hinshelwood model would involve the addition of a hydrogen term to the denominator, with an equilibrium constant that would be almost an order of magnitude grapter than that. for steam. The Ergun model does of course handle Lhis prublem as well.

Schmal et al. (1982) studied the steam gasification of the char from run-of-mine Charqueadas coal, a high ash ( $56 \%$ ) subbituminous Brazilian coal ( $19.8 \%$ volatiles), at temperatures between 800 and $1000^{\circ} \mathrm{C}$. They analyzed their results on the basis ot both the shrinking corc model of Levenspiel (1967) and lite continuous model of Wen (1968) that assumes that all subparticles react uniformly. The shrinking core model includes three resistances: (1) diffusion through a stagnant gas film around the particle; (2) diffusion through the ash layer; and (3) chemical reaction at the char surfacc. Confirming the results of Jensen (1975) and of Chan and Papic (1976), they found that only the reaction at the surface is the controliing step. In this case, the time $t$ required to attain a given conversion $X$ is given by: the : equation: 


$$
t / t a v=1-(1-X)^{1 / 3}
$$

where

$$
\begin{aligned}
\text { tau } & =\mathrm{R}_{0} \mathrm{C}_{0} / \mathrm{K}_{\mathrm{H} 2 \mathrm{P}{ }^{\mathrm{n}}} \\
& =\text { time for total conversion, min } \\
\mathrm{R}_{0} & =\text { mean radius of the particles } \\
\mathrm{C}_{0} & =\text { intial concentration of carbon, mol } / \mathrm{cm}^{3} \\
\mathrm{~K} & \left.=\text { rate constant, mol/( } \mathrm{cm}^{2} \text { atm } \mathrm{min}\right) \\
\mathrm{P}_{\mathrm{H} 20} & =\text { partial pressure of } \mathrm{H}_{2} \mathrm{O}
\end{aligned}
$$

and for this particular coal char:

$$
R=1350 \exp (-39500 / R T) \operatorname{mol} /\left(\mathrm{cm}^{2} \min a t \mathrm{~m}^{\mathrm{n}}\right) \text {. }
$$

Conversion for the continuous model is represented by the rate expression

$$
\mathrm{dX} / \mathrm{dt}=\mathrm{k} \mathrm{p}_{\mathrm{H}_{2} \mathrm{O}^{\mathrm{n}}(1-\mathrm{X})}
$$

which at constant partial pressure of the steam integrates to:

$$
-\ln (1-X)=\left(k \mathrm{p}_{\mathrm{H}_{2}} 0^{\mathrm{n}}\right) \mathrm{t}
$$

and for this particular coal char:

$$
k=2.4 \times 10^{6} \exp [-39500 / R T] \min ^{-1} a^{-n}
$$

Neither model fits the data over the entire temperature range studied by Schmal et al.. The continuous model is best at $800^{\circ} \mathrm{C}$; at $850^{\circ} \mathrm{C}$ the results are intermediate between the two models; and at 900,950 and $1000^{\circ} \mathrm{C}$ the shrinking core model gields a very good fit. The activation energies are the same for both models, and their magnitude agrees with the absence of diffusional resistance at these temperatures. The experiments were performed at 1 atmosphere, so that the magnitude of the exponent $n$ is indeterminate, but from the results of other workers we know that 
$n=1$. The following average rates were observed:

\begin{tabular}{|c|c|c|c|c|c|}
\hline \multirow{2}{*}{ Temperature, ${ }^{\circ} \mathrm{C}$} & 800 & 850 & 900 & 950 & 1000 \\
\hline & \multicolumn{5}{|c|}{ Average rate, $\min ^{-1}$} \\
\hline 0 to $50 \%$ conversion & 0.0156 & 0.033 & 0.069 & 0.133 & 0.300 \\
\hline 0 to $80 \%$ conversion & 0.0115 & 0.027 & 0.056 & 0.113 & 0.226 \\
\hline
\end{tabular}

Muhlen et al. (1987) studied the kinetics of $\mathrm{O}_{2}$ chemisorption on chars and its relevance to char reactivity. They concluded that, at this time, only relative changes in the reactivity of chars originating from the same coal can be predicted from chemisorption results. The absolute magnitude of the reactivity cannot yet be predicted from such experiments alone. For a German bituminous coal (Westerholt) ( $2.1 \%$ moisture, $3.9 \%$ ash and $37.4 \%$ volatile matter), the initial reaction rate in 40 bar steam at $850^{\circ} \mathrm{C}$ was $0.075,0.062$ and $0.031 \mathrm{~min}^{-1}$ for chars prepared at 700 , 800 and $900^{\circ} \mathrm{C}$ respectively. However, as conversion proceeded, all three rates converged to the single value of $0.043 \mathrm{~min}^{-1}$ at $80 \%$ conversion.

\subsubsection{Carbon-Hydrogen-Methane System}

The forward reaction of

$$
\mathrm{C}+2 \mathrm{H}_{2} \longleftrightarrow==\mathrm{CH}_{4}
$$

halves the volume of the gas phase and consequently proceeds less slowly as pressure is elevated. Johnson correlated the reaction. rate in terms of the equation: 


$$
\text { rate }=\mathrm{k}_{\mathrm{H}} \mathrm{p}_{\mathrm{H}_{2}}^{2} /\left(1+\mathrm{R}_{\mathrm{H}} \mathrm{p}_{\mathrm{H}_{2}}\right)
$$

For air-pretreated bituminous coal chars, prepared at the same temperatures as the subsequent gasification in hydrogen, at hydrogen pressures up to 70 atm and temperatures of $800-1050^{\circ} \mathrm{C}$, Johnson (1982) obtained the following constants for equation (40):

$$
\begin{aligned}
& \mathrm{k}_{\mathrm{H}}=\exp [2.6741-27170 / \mathrm{RT}] \\
& \mathrm{R}_{\mathrm{H}}=\exp [-10.452+22050 / \mathrm{RT}]
\end{aligned}
$$

with $k_{H}$ in min-1atm ${ }^{-1}, K_{H}$ in atm $m^{-1}, R$ in cal-mole $e^{-1} R^{-1}$, and $T$ in kelvins. Calculations based on equations (40), (41) and (42) yield the following rates as a function of temperature and hydrogen pressure:

\section{TABLE 7}

Gasification rate of bituminous coal in $\underline{\mathrm{H}}_{2}$ to $\underline{\mathrm{CH}}_{4}$

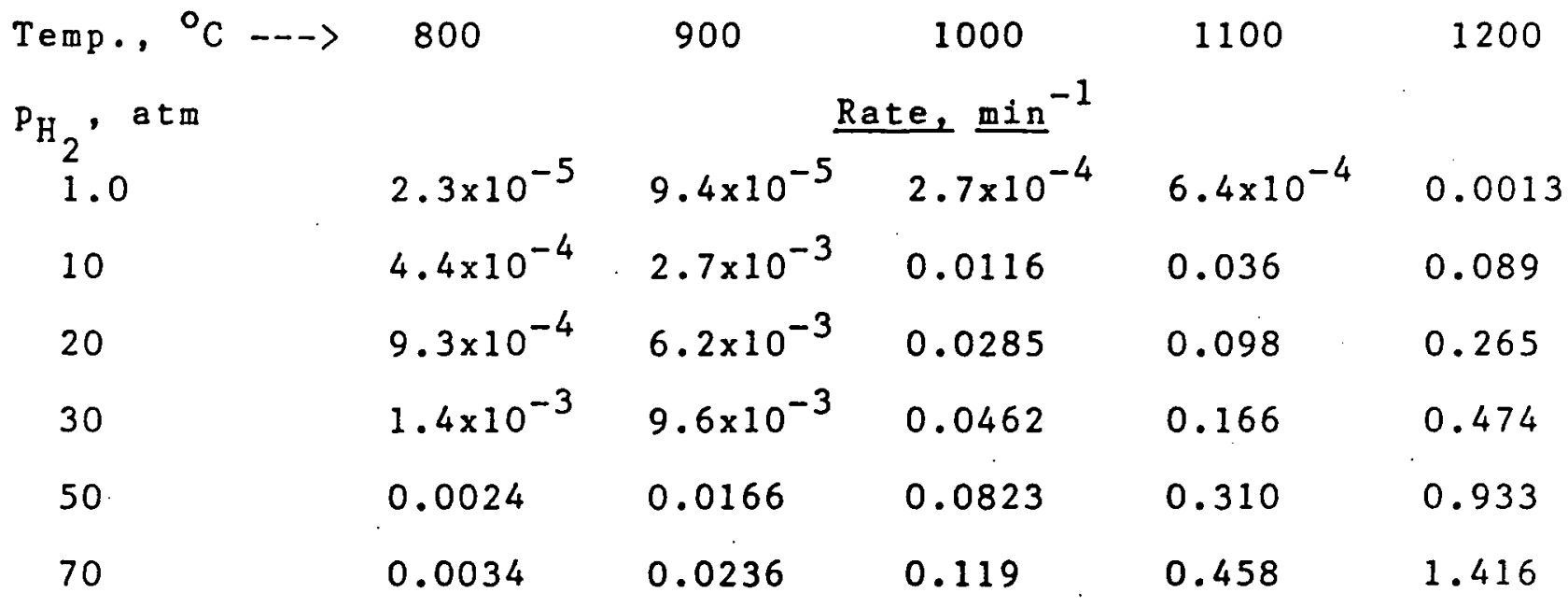

The last two columns represent extrapolations. The actual rates at those higher temperatures mag be overstated, because diffusional resistances become increasingly important as the k1netic resistance to reaction decreases. 
Johnson also presents a simplification of rate equation (40):

where

$$
\begin{aligned}
& \text { rate }=\mathrm{k}^{*} \mathrm{p}_{\mathrm{H}_{2}} \\
& \mathrm{k}^{*}=\mathrm{k}_{\mathrm{H}} / \mathrm{K}_{\mathrm{H}}
\end{aligned}
$$

Comparison with equation (40) shows that this simplification is valid provided that $1<<R_{H} p_{H}$. The following tabulation is made to examine the validity of that assumption.

\section{TABLE 8}

Magnitude of $\underline{\mathrm{K}}_{\mathrm{H}} \mathrm{P}_{\mathrm{H}}$ for bituminoug cos1

$\begin{array}{rccccc}\text { Temp., }{ }^{\circ} \mathrm{C} \rightarrow & 800 & 900 & 1000 & 1100 & 1200 \\ \mathrm{P}_{\mathrm{H}_{2}}, \text { atm } & & & \mathrm{R}_{\mathrm{H}} \mathrm{P}_{\mathrm{H}_{2}} & & \\ 1 & 0.881 & 0.365 & 0.174 & 0.092 & 0.053 \\ 10 & 8.81 & 3.65 & 1.74 & 0.923 & 0.534 \\ 20 & 17.62 & 7.31 & 3.48 & 1.85 & 1.07 \\ 30 & 26.42 & 11.0 & 5.22 & 2.77 & 1.60 \\ 50 & 44.0 & 18.3 & 8.70 & 4.61 & 2.67 \\ 70 & 61.7 & 25.6 & 12.2 & 6.46 & 3.74\end{array}$

The table shows that $\mathrm{K}_{\mathrm{II}} \mathrm{p}_{\mathrm{II}}$ indeed becomes much larger than 1 as the pressure increases, but that this is more true at lower temperatures. At the higher temperatures, there is a substantial error involved in using the simplified equation, as $\mathrm{R}_{\mathrm{H}} \mathrm{P}_{\mathrm{H}_{2}}$ is not that much larger than 1 , except at the highest. pressures.

In general, investigators found that there are two primary reasons for the varlations in reactivity of various chars. One is the inherent differences in properties between coals; the other is: due to the conditions employed in preparing the char. In general; the more severe preparation conditions lead to a loss in 
reactivity. For chars prepared at temperatures lower than or equal to the subsequent gasification temperature, Blackwood et al.

(1967) developed the equation:

$$
k^{*}=k_{H O} \exp \left[E_{p} / R T_{p}\right] \exp \left[E_{8} / R T_{8}\right]
$$

where $T_{p}$ is the char preparation temperature, $T_{g}$ the gasification temperature $\left(T_{p} \leq T_{g}\right)$. For brown coal chars, Blackwood et al. determined the following values:

$$
\begin{aligned}
& E_{p}=20 \mathrm{kcal} / \mathrm{mole} \\
& E_{g}=50 \mathrm{kcal} / \mathrm{mole} \\
& k_{H O}=37.0 \mathrm{~atm}^{-1} \mathrm{~min}^{-1}
\end{aligned}
$$

Substitution of these values into equation (45) yields the following results $\left(T_{p}=T_{g}\right)$ :

$\begin{array}{llllll}\text { Temperature, }{ }^{\circ} \mathrm{C} & 700 & 800 & 900 & 1000 & 1100\end{array}$ $k^{*}$, min ${ }^{-1} \operatorname{atm}^{-1} \quad 7.1 \times 10^{-6} \quad 3.0 \times 10^{-5} \quad 1.0 \times 10^{-4} \quad 2.7 \times 10^{-4} \quad 6.5 \times 10^{-4}$ The actual rate of reaction is obtained by multiplying $k^{*}$ by the partial pressure of hydrogen. If the char preparation temperature is less than the gasification temperature, then the rate constant increases in accordance with equation (45). Blackwood's data were obtained at pretreatment temperature ranges of 750 to $950{ }^{\circ} \mathrm{C}$. Johnson, working with char from high volatile bituminous coal and using pretreatment temperatures from $927{ }^{\circ} \mathrm{C}$ to $1100^{\circ} \mathrm{C}$ expressed the rate by the equation

$$
\begin{aligned}
\text { rate } & =(d X / d t) /(1-X) \\
& =\left[k_{1} \exp \left(E_{p} / R T_{p}\right) \exp \left(-E_{g} / R T_{g}\right) p_{H_{2}}^{2}\right] /\left[p_{H_{2}}+k_{2}\right]
\end{aligned}
$$

and obtained the following parameter values: 


$$
\begin{aligned}
& E_{p}=9.34 \mathrm{kcal} / \mathrm{mole} \\
& E_{8}=58.6 \mathrm{kcal} / \mathrm{mole} \\
& k_{1}=5.02 \times 10^{5} \mathrm{~atm}^{-1} \mathrm{~min}^{-1} \\
& k_{2}=\exp (10.452-22050 / \mathrm{RT})
\end{aligned}
$$

Johnson attributes the change in reactivity with preparation temperature primarilg to the variation in the number of active sites on the carbon surface. He was able to normalize his own results and those of Blackwood, by defining a "normalized active site concentration function", phi, which in effect is a correction factor for the effect of variations in the char preparation temperature. Phi equals 1 at the reference char preparation temperature of $950^{\circ} \mathrm{C}$. Johnson obtained a good fit to his own data and those of Blackwood with the equation:

$$
\text { phi }=260 /(T-707)
$$

where $\mathrm{T}$ is in ${ }^{\circ} \mathrm{C}$. This equation, though it fits the data well, has the drawack that it brcako down at temperatures near and below $707^{\circ} \mathrm{C}$. Thus it should not be used below about $750^{\circ} \mathrm{C}$.

The total concentration of active sites in coal chars is given by the equation:

$$
\mathrm{n}_{\mathrm{T}}=\mathrm{S} \mathrm{c}_{\mathrm{a}}
$$

where $S=$ total internal char surface area ( $\mathrm{m}^{2} /$ mole of carbon), and

$$
c_{a}=\text { concentration of active sites }\left(m o l e / m^{2}\right) \text {. }
$$

Evidence presented by Johnson indicates that $S$, the total internal surface area, does not change with preparation temperature, and that the decrease in reactivity with increasing char preparation: : 
temperature is due to a decrease in the concentration of active sites. Johnson also found that both $S$ and $C_{a}$ remain constant with most coal chars at least up to carbon conversions of $80 \%$ to $90 \%$, which implies that the rate of gasification does not change as conversion proceeds. All these effects are summarized by Johnson in equation (49) for the rate of char gasification in hydrogen, with the parameters given by equations (50)-(53). Equation. (49) simultaneously considers the effects of pretreatment temperature, gasification temperature, and hydrogen partial pressure on the rate of hydrogen gasification of brown coal char to methane. The results, using the parameters of equations (50) through (53), are displayed in Table 9.

\section{TABLE 9}

Gasification rate of brown coal in $\underline{H}_{2}$ to $\underline{C H}_{4}$

\begin{tabular}{|c|c|c|c|c|}
\hline Temp., ${ }^{\circ} \mathrm{C}--->$ & 800 & 900 & 1000 & 1100 \\
\hline $\mathrm{p}_{\mathrm{H}_{2}}$, atm & \multicolumn{4}{|c|}{$\underline{\text { Rate, }}_{\text {min }^{-1}}$} \\
\hline atm & \multicolumn{4}{|c|}{ (Char prepared at $800^{\circ} \mathrm{C}$ ) } \\
\hline 10 & $4.5 \times 10^{-4}$ & $4.0 \times 10^{-3}$ & 0.0235 & 0.0955 \\
\hline 30 & $1.4 \times 10^{-3}$ & 0.0141 & 0.0930 & 0.439 \\
\hline 50 & 0.0024 & 0.0244 & 0.166 & 0.818 \\
\hline 70 & 0.0034 & 0.0346 & 0.239 & 1.206 \\
\hline \multicolumn{5}{|c|}{ (Char prepared at $900^{\circ} \mathrm{C}$ ) } \\
\hline 10 & & $2.8 \times 10^{-3}$ & 0.0161 & 0.0656 \\
\hline 30 & & $9.7 \times 10^{-3}$ & 0.0639 & 0.301 \\
\hline 50 & & 0.0167 & 0.114 & 0.562 \\
\hline 70 & & 0.0238 & 0.164 & 0.829 \\
\hline
\end{tabular}


TABLE 9 (continued)

Gasification rate of brown coal in $\mathrm{H}_{2}$ to $\mathrm{CH}_{4}$

\begin{tabular}{|c|c|c|c|c|}
\hline Temp., ${ }^{\circ} \mathrm{C}-->$ & 800 & 900 & 1000 & 1100 \\
\hline $\mathrm{P}_{\mathrm{H}}$, atm & \multicolumn{4}{|c|}{ Rate, min $^{-1}$} \\
\hline & & (Char $p$ & 1 at 10 & \\
\hline 10 & & & 0.0117 & 0.0478 \\
\hline 30 & & & 0.0466 & 0.220 \\
\hline 50 & & & 0.0829 & 0.410 \\
\hline 70 & . & & 0.120 & $0.60 / 4$ \\
\hline
\end{tabular}

Johnson also determined a general trend for a relative reactivity factor $f_{L}$ as a function of the moisture and ash-free (m.a.f.) carbon content, $Y$, of the raw coals:

$$
\mathrm{f}_{\mathrm{L}}=6.2 \mathrm{Y}(1-\mathrm{Y})
$$

for

$$
0.67 \leq \mathrm{Y} \leq 0.93
$$

Equation (56) must be used with caution, as many factors other than carbon content affect reactivity, hence the equation includes considerable scatter.

\section{1 .4 Carbon-0xygen Reaction}

Perlmutter (1083) otudicd the cffecto of pore ctructuro and of inorganic catalysts on the rate of the carbon-oxygen reaction. Although this particular reaction was chosen for this study, many of the conclusions should be rather generally applicable to other gasification reactions. Perlmutter's work included an anthracite 
( $13.94 \%$ ash, $5.77 \%$ volatile matter) char and chars prepared from Rentucky high volatile A bituminous coal (2.1\% ash, $37.5 \%$ volatile matter). The anthracite char and one of the bituminous coal chars were prepared by pyrolysis at a $10^{\circ} \mathrm{C} / \mathrm{min}$ heating rate to a final temperature of $600^{\circ} \mathrm{C}$. Two bituminous coal chars were made at the heating rate of $10^{\circ} \mathrm{C} / \mathrm{min}$, but at final pyrolysis temperatures of 750 and $950^{\circ} \mathrm{C}$. The other two chars were made at the base-case final temperature of $600^{\circ} \mathrm{C}$, but at heating rates of $5^{\circ} \mathrm{C} / \mathrm{min}$ and $1^{\circ} \mathrm{C} / \mathrm{min}$. The char samples were characterized by a series of physical measurements:

- The macropore volume and its size distribution were determined by mercury porosimetry

- The micropore volume was determined by $\mathrm{CO}_{2}$ adsorption at $0^{\circ} \mathrm{C}$ (Nitrogen adsorption at $-196^{\circ} \mathrm{C}$ yielded surface areas two orders of magnitude smaller and was considered inadequate).

- The apparent particle density was determined by pycnometry. From this information, Perlmutter calculated the pore structure parameter used in the Bhatia and Perlmutter (1980) model and defined as:

$$
p s i=4 p i L_{0}\left(1-\operatorname{epsilon_{0}}\right) / s_{0} 2
$$

where $\quad p i=3.14$

$L_{0}=$ total pore length per unit weight of unreacted particle, $\mathrm{m} / \mathrm{g}$

epsilon $=$ initial porosity (dimensionless)

$S_{0}=$ actual initial surface area per unit volume of reacting particle, $\mathrm{m}^{2} / \mathrm{m}^{3}$. 
Perlmuter found that the reactions were in the chemical kinetic control regime at particle sizes below 250 microns and temperatures below $455^{\circ} \mathrm{C}$. For this regime, the random pore model of Bhatia and Perlmutter (1980) predicts the rate of change of carbon conversion as

$$
d X / d t=k_{s} c_{0}{ }^{n} S_{0}(1-X)[1-p s i . \ln (1-X)]^{1 / 2} /(1-\operatorname{epsilon})
$$

where the quantity $k_{s} C_{0}^{n}$ is the intrinsic reaction rate. For all the chars, Perlmutter found that the kinetics were first order $(n=1)$. Good fits were obtained using the value of the pore structure parameter determined from physical measurements, thus demonstrating the usefulness of the model. Perlmutter also studied the effect of catalysts. This portion of his work is discussed in another section of this report.

Hamblen et al. (1986) measured the reactivity of chars from a wide range of coals by measuring their rate of combustion in air. They define $T_{C r}$ as the temperature at which the rate of weight loss is $0.11 \mathrm{~min}^{-1}$, and tau 0.1 as the time for 10\% burnoff. A plot of tau 0.1 versus $1 / T_{c r}$ yields a jeraight line for the coalo thoy studied: Rosebud subbituminous, Pittsburgh b1tuminous, Zap lignite and Zap demineralized lignite. The approximate equation for that line is:

$$
\operatorname{tau}_{0.1}=1.14 \times 10^{12} \exp (-34800 / 1.99 \mathrm{~T})
$$

with $\mathrm{T}$ in kelvins.

The critical temperature, $T_{C r}$, depends on the rank of the coa: and other coal characteristics, and on the degree of devolatilization during pyrolysis. Typical values of $T_{C r}$ are displaged in Table 10. 
during pyrolysis. Typical values. of $\mathrm{T}_{\mathrm{cr}}$ are displaged in Table 10. TABLE 10

\section{Critical Temperatures of Various Coal Chars}

\begin{tabular}{|c|c|c|c|c|c|c|c|}
\hline Wt.\% H (daf & & 0.5 & 1.0 & 2.0 & 3.0 & 4.0 & 5.0 \\
\hline Rentucky \#9 & $1 /$ & 580 & 560 & 530 & 510 & 495 & n.a. \\
\hline Pittsburgh & $2 /$ & n.a. & n.a. & 510 & 485 & 472 & 467 \\
\hline$"$ & $3 /$ & 493 & 487 & 468 & 454 & 440 & 424 \\
\hline Zap & 41 & 500 & 444 & 383 & 350 & 345 & n. a. \\
\hline$"$ & $5 /$ & n. 8 . & 505 & $\mathrm{n} \cdot \mathrm{a}$. & n.a. & n. a. & n.a. \\
\hline Rosebud & $6 /$ & n.a. & 450 & $\mathbf{n} \cdot \mathbf{a}$ & n.a. & n.a. & n.a. \\
\hline
\end{tabular}

$1 /$ Char made in entrained flow reactor at $1600^{\circ} \mathrm{C}$

2/ Char made in entrained flow reactor at $1100^{\circ} \mathrm{C}$

$\underline{3} /$ Char made at a heating rate of $30^{\circ} \mathrm{C} / \mathrm{min}$

$4 /$ Chars made in entrained flow reactor at $1600,1300,1100$, and $800^{\circ} \mathrm{C}$, and at $30^{\circ} \mathrm{C} / \mathrm{min}$ heating rate.

5/ Char made from demineralized Zap 1 ignite at $30^{\circ} \mathrm{C} / \mathrm{min}$ heating rate

6/ Char made from Rosebud coal at $30^{\circ} \mathrm{C} / \mathrm{min}$ heating rate 


\subsubsection{Carbon-Carbon Dioxide Reaction}

McCoy et a1. (1981) studied both the carbon-carbon dioxide and the carbon-steam reactions. The latter are discussed under the appropriate heading. The $\mathrm{CO}_{2}$ gasification of $\mathrm{R}_{2} \mathrm{CO}_{3}$-catalyzed char proceeded at 5 to 10 times the rate of the noncatalyzed char. With noncatalyzed char, at pressures ranging from $0.1 \mathrm{MPa}$ to $3.5 \mathrm{MPa}$, the gasification rate increased monotonically with increasing pressure, but for catalyzed char the effect of pressure was inconsistent and depended on the temperature in the $650^{\circ} \mathrm{C}$ to $850^{\circ} \mathrm{C}$ range. For the uncatalyzed char, the surface area per gram increased monotonically as char conversion progressed, while the catalyzed char area per gram increased up to about $50 \%$ to $65 \%$ conversion and then decreased. In addition, the surface area per gram of catalyzed char is always lower than that of the uncatalyzed char. This would be in agreement with Perlmutter's observation that the non-catalytic reaction proceeds within the pore space with an increase in pore volume as the reaction proceeds, while the catalyzed reaction proceeds on the outer surface. This is explained clearly in the Vanderbilt University report which points out that, when the kinetics are very rapid, reactant gases are consumed as soon as they reach the char: surface, and do not have the opportunity to penetrate the: pore space. Perlmutter states that a non-catalytic reaction takes: place: 
within the pore space at the same time as the catalytic reaction occurs on the outside of each particle. If the outside area were of the same order of magnitude as the pore area, then the more rapid catalgtic reaction would eliminate the opportunity for reactant gases to penetrate the pore space. But because the pore area is so much larger, the non-catalytic reaction can proceed along with the catalytic one.

The final report by McCoy et al. (1983) contains extensive data on the rates of catalyzed gasification reactions for char prepared from Illinois \#6 coal. Some of the $\mathrm{CO}_{2}$ rate data may be summarized as follows:

$$
750^{\circ} \mathrm{C}
$$$$
850^{\circ} \mathrm{C}
$$

Pressure Rate, $\underline{\text { min }}^{-1}$

No catalyst:
1 bar
$0.8 \times 10^{-3}$
18 bar
$2.0 \times 10^{-3}$
35 bar
$0.3 \times 10^{-3}$
$3.5 \times 10^{-3}$

$\mathrm{R}_{2} \mathrm{CO}_{3}$ catalyst ( $\mathrm{K} / \mathrm{C}$ atomic ratio $=0.04$ ):

18 bar

35 bar

$\begin{array}{ll}6 \times 10^{-3} & 14 \times 10^{-3} \\ 6 \times 10^{-3} & 23 \times 10^{-3}\end{array}$

Other potassium salts $(R / C=0.04)$ :

$\begin{array}{llr}\mathrm{KOH} & 35 \text { bar } & 5.5 \times 10^{-3} \\ \mathrm{R}_{2} \mathrm{SO}_{4} & 35 \text { bar } & 4 \times 10^{-3} \\ \mathrm{KNCO} & 35 \text { bar } & 3.2 \times 10^{-3} \\ \mathrm{KCl} & 35 \text { bar } & 2.2 \times 10^{-3}\end{array}$


Other alkali metal carbonates (metal/C atomic ratio = 0.04):

$\begin{array}{lll}\mathrm{Cs}_{2} \mathrm{CO}_{3} & 35 \text { bar } & 10 \times 10^{-3} \\ \mathrm{Na}_{2} \mathrm{CO}_{3} & 35 \text { bar } & 4 \times 10^{-3} \\ \mathrm{LI}_{2} \mathrm{CO}_{3} & 35 \text { bar } & 2 \times 10^{-3}\end{array}$

Chloride catalysts (metal/C atomic ratio $=0.04$ ):

RC1

35 bar

$2.2 \times 10^{-3}$

L1C1

35 bar

$1.3 \times 10^{-3}$

Lime catalyst ( $\mathrm{Ca} / \mathrm{C}$ atomic ratio $=0.024)$ :
$\mathrm{CaO}$
.3 bar
$3.5 \times 10^{-3}$
$\mathrm{CaO}$
18 bar
$3.2 \times 10^{-3}$
$11.5 \times 10^{-3}$
$\mathrm{CaO}$
35 bar
$1.1 \times 10^{-3}$

McCoy et a1. ( 1983 ) determined the parameters $k_{1}$ and $\pi_{1}$ for the Temkin (1979) rate equation

$$
\text { rate }=k_{1}\left[p_{\mathrm{CO}_{2}} /\left(1+R_{1} p_{\mathrm{CO}}\right)\right]^{1 / 2}
$$

where the rate is in $\mathrm{min}^{-1} \mathrm{MPa}^{-1 / 2}$ and partial pressures are in $\mathrm{MPa}$, with the following results:

$\mathrm{k}_{1}$, noncatalyzed char, min ${ }^{-1} \mathrm{MPa}^{-1 / 2}$

$$
750{ }^{\circ} \mathrm{C}
$$

$850{ }^{\circ} \mathrm{C}$

$\mathrm{k}_{1}, \mathrm{~K}_{2} \mathrm{CO}_{3}$-cat. char $(\mathrm{K} / \mathrm{C}=0.04)$

$5 \times 10^{-5}$ $1 \times 10^{-5}$

$\mathrm{R}_{1}$ noncatalyzed char, $\mathrm{MPa}^{-1}$ $24 \times 10^{-5}$

$\mathrm{R}_{1}, \mathrm{R}_{2} \mathrm{CO}_{3}$-cat. char $(\mathrm{R} / \mathrm{C}=0.04)$ 
Freund (1985) studied the catalyzed and uncatalyzed gasification of carbons and a $1000^{\circ} \mathrm{C}$ char made from Illinois \#6 coal. He found that under the conditions of his experiments (temperatures up to $900^{\circ} \mathrm{C}$ for uncatalyzed runs and $800^{\circ} \mathrm{C}$ for catalyzed runs) the Ergun model [refer to reactions (2) and (3)] was satisfactory for both catalyzed and uncatalyzed runs. The effect of the catalyst was found to be an increase in the concentration of active sites. Freund modified the Ergun rate equation (4) by replacing the rate constant k by a product $k_{i}$ $\left[\mathrm{C}_{\mathrm{T}}\right]$, where $k_{i}$ is the intrinsic rate constant and $\left[\mathrm{C}_{\mathrm{T}}\right]$ is the active site density, $g$ of active carbon/ $g$ of total carbon, and

$$
C_{T}=C_{f}+C_{o}
$$

is the sum of the free and occupied active sites. Freund found that the equilibrium constant for reaction (2) was close to the value determined by Ergun, indicating that the equilibrium of that reaction was unaffected by the presence of catalyst. The intrinsic rate constant for reaction (3) from regression analysis is reported by Freund as:

$$
k_{i}=10^{\mathrm{x}} \exp \left[-E_{a} / R T\right]
$$

where the $95 \%$ confidence limits are:

$$
x=11.6 \pm 2.6
$$

and

$$
E_{a}=53700 \pm 9400
$$

Substitution in equation (60) gields the values for the intrinsic rate constant $k_{i}$ listed in Table 11 . 
$\underline{\text { TABLE }} \underline{11}$

\section{Active carbon area for three carbons}

\begin{tabular}{|c|c|c|c|c|}
\hline Temp., ${ }^{\circ} \mathrm{C}-->$ & 800 & 900 & 1000 & 1100 \\
\hline \multirow[t]{2}{*}{$k_{i}$} & 4.78 & 40.8 & 248 & 1162 \\
\hline & \multicolumn{4}{|c|}{ Coke breeze } \\
\hline k & $5.1 \times 10^{-5}$ & $8.0 \times 10^{-4}$ & 0.0082 & 0.0594 \\
\hline \multirow[t]{2}{*}[\mathrm{C}_{\mathrm{T}}]{, $\mathrm{g} / \mathrm{g}$} & $1.1 \times 10^{-5}$ & $2.0 \times 10^{-5}$ & $3.3 \times 10^{-5}$ & $5.1 \times 10^{-5}$ \\
\hline & \multicolumn{4}{|c|}{ Uncatalyzed Illinois \#6 coal char } \\
\hline k & $3.1 \times 10^{-4}$ & $3.3 \times 10^{-3}$ & 0.0242 & 0.132 \\
\hline \multirow[t]{2}{*}[\mathrm{C}_{\mathrm{T}}]{, $\mathrm{g} / \mathrm{g}$} & $6.5 \times 10^{-5}$ & $8.1 \times 10^{-5}$ & $9.7 \times 10^{-5}$ & $1.1 \times 10^{-4}$ \\
\hline & $20 \% \mathrm{~K}_{2} \mathrm{CO}_{3}$ & catalyzed & Illinois \#6 & coal char \\
\hline $\mathrm{k}$ & 0.175 & 1.74 & 12.1 & 63.2 \\
\hline$\left[\mathrm{C}_{\mathrm{T}}\right], \mathrm{g} / \mathrm{g}$ & $3.7 \times 10^{-2}$ & $4.3 \times 10^{-2}$ & $4.9 \times 10^{-2}$ & $5.4 \times 10^{-2}$ \\
\hline
\end{tabular}

The values of $\left[\mathrm{C}_{\mathrm{T}}\right]$ are remarkably constant considering that we have combined Freund's data and Katta \& Keairns' coke breeze data to calculate the density of active sites. Freund determined a value or $4.7 \times 10^{-5}$ fur the active site density of uneatalyzed carbon. From Freund's figure 3 , the following equations were derived:

for uncatalyzed Illinois \#6 coal char:

$$
k=3.27 \times 10^{8} \exp [-59116 / \mathrm{RT}]
$$

and for Illinoic $\# 6$ coal char catalyzed by $20 \% \mathrm{~K}_{2} \mathrm{CO}_{3}$ :

$$
k=8.90 \times 10^{10} \exp [-57564 / R T]
$$

Because the values are calculated from plotted values, the small difference in activation energies is not considered significant, 
but there is a difference of more than two orders of magnitude in the preexponential constant, reflecting a large increase in active sites with the addition of $20 \%$ by weight of $\mathrm{R}_{2} \mathrm{CO}_{3}$. In Table 11 , the fraction of carbon that constitute active sites is $\left[\mathrm{C}_{\mathrm{T}}\right]$, and it is calculated by means of the equation:

$$
\left[\mathrm{C}_{\mathrm{T}}\right]=\mathrm{k} / \mathrm{k}_{\mathrm{i}}
$$

In all cases the active carbon density is nearly constant over the entire temperature range. The table shows a fourfold increase in the density of active sites in going from the coke breeze to the Illinois \#6 coal char, and a 500-fold increase in active site density in going from uncatalyzed char to the char with $20 \% \mathrm{~K}_{2} \mathrm{CO}_{3}$.

\subsubsection{Carbon-Steam Reaction}

McCoy et al. (1981) investigated the mechanism of coal- $\mathrm{CO}_{2}$ and steam gasification reactions. For steam gasification, they found an increase in catalytic activity in the sequence:

$$
\mathrm{Li}<\mathrm{Na}<\mathrm{R}<\mathrm{Cs}
$$

when these elements were incorporated into Illinois \#6 coal prior to charring in the ratio of four metal atoms per 100 carbon atoms. The final report by McCoy et al. (1983) contains extensive data on the rates of catalyzed gasification reactions for char prepared from Illinois \#6 coal. Some of the steam rate data may be summarized as follows: 
No catalyst:

1 bar

18 bar

$$
3 \times 10^{-3}
$$$$
21 \times 10^{-3}
$$

35 bar

$\mathrm{R}_{2} \mathrm{CO}_{3}$ catalyst, $\mathrm{K} / \mathrm{C}$ atomic ratio $=0.04$

$$
\begin{array}{r}
0.3 \text { bar } \\
18 \text { bar } \\
35 \text { bar }
\end{array}
$$

$\mathrm{K}_{2} \mathrm{CO}_{3}$, various atomic ratios

$$
\begin{aligned}
R / C= & 0.013,35 \mathrm{bar} \\
& 0.026,35 \mathrm{bar} \\
& 0.08,35 \mathrm{bar}
\end{aligned}
$$

$$
21 \times 10^{-3}
$$$$
27 \times 10^{-3}
$$$$
48 \times 10^{-3}
$$$$
19 \times 10^{-3}
$$

$13 \times 10^{-3}$

$17 \times 10^{-3}$

$30 \times 10^{-3}$

Various potassium salts, $K / C=0.04$

$\begin{array}{lll}\mathrm{KOH} & 35 \text { bar } & 32 \times 10^{-3} \\ \mathrm{R}_{2} \mathrm{CO}_{3} & 35 \text { bar } & 24 \times 10^{-3} \\ \mathrm{RNCO} & 35 \mathrm{bar} & 22 \times 10^{-3} \\ \mathrm{R}_{2} \mathrm{SO}_{4} & 35 \mathrm{bar} & 20 \times 10^{-3} \\ \mathrm{RCl} & 35 \mathrm{bar} & 7 \times 10^{-3} \\ \text { Other alkal1 metal carbonates (metal/C atomic ratio = } & 0.04 \text { ) } \\ \mathrm{Cs}_{2} \mathrm{CO}_{3} & 35 \text { bar } & 27 \times 10^{-3} \\ \mathrm{R}_{2} \mathrm{CO}_{3} & 35 \text { bar } & 19 \times 10^{-3} \\ \mathrm{Na}_{2} \mathrm{CO}_{3} & 35 \text { bar } & 11 \times 10^{-3} \\ \mathrm{Li}_{2} \mathrm{CO}_{3} & 35 \text { bar } & 7 \times 10^{-3}\end{array}$


rate, min

Chloride catalgsts. (metal/C atomic ratio $=0.04$ )

$\begin{array}{lll}\mathrm{KC} 1 & 35 \text { bar } & 6 \times 10^{-3} \\ \mathrm{LICl} & 35 \text { bar } & 5 \times 10^{-3}\end{array}$

Lime catalyst ( $\mathrm{Ca} / \mathrm{C}$ atomic ratio $=0.024$ )

$\begin{array}{cccc}\mathrm{CaO} & .3 \text { bar } & 8 \times 10^{-3} \\ \mathrm{CaO} & 18 \text { bar } & 12 \times 10^{-3} \\ \mathrm{CaO} & 35 \text { bar } & 14 \times 10^{-3}\end{array} \quad 40 \times 10^{-3}$

All the above rates are initial rates at the start of gasification. Use of these rates is conservative, as the authors generally. report substantial rate increases as conversion proceeds. However, if the rates were based on the initial weight of char instead of the remaining weight, the rates would be nearly constant until complete conversion is approached. Thus the initial rate is useful to estimate the time required to gasify a given fraction of the char.

McCoy et a1. also report that partially gasified chars contalning effective catalysts were found to be intensely pyrophoric after $\mathrm{H}_{2}$ or $\mathrm{H}_{2} \mathrm{O}$ gasification. This behavior was not observed after $\mathrm{CO}_{2}$ gasification or gasification with noncatalgzed or CaO-catalyzed chars.

In an interim report on this work, Rosky et al, (1982) presented extensive reactivity data as a function of temperature in the form of Arrherius plots. A few of their results may be 
summarized as follows for Il1inois \#6 char in $\mathrm{CO}_{2}$ at 1 atm (all rates in $\mathrm{min}^{-1}$ ):

$$
\text { (catalyst post-added): }
$$

uncatalyzed: rate $=8.44 \times 10^{5} \exp [-47700 / \mathrm{RT}]$

$5 \% \mathrm{R}_{2} \mathrm{CO}_{3}$ catalyzed: rate $=3.98 \times 10^{7} \exp [-50400 / \mathrm{RT}]$

$20 \% \mathrm{Na}_{2} \mathrm{CO}_{3}$ catalyzed: rate $=4.41 \times 10^{8} \exp [-52800 / \mathrm{RT}]$

The catalyst increases the pre-exponential constant, Indicating an increase in the number of active sites; the activation energy is essentially unchanged.

(catalgst pre-added):

uncatalyzed: rate $=1.05 \times 10^{6} \exp [-47700 / \mathrm{RT}]$

$5 \% \mathrm{~K}_{2} \mathrm{CO}_{3}$ catalyzed: rate $=3.75 \times 10^{6} \exp [-44500 / \mathrm{RT}]$

The authors also confirmed the negative effect of high coal heattreatment temperatures (HTT) on the density of the active sites:

Illinois \#6 char

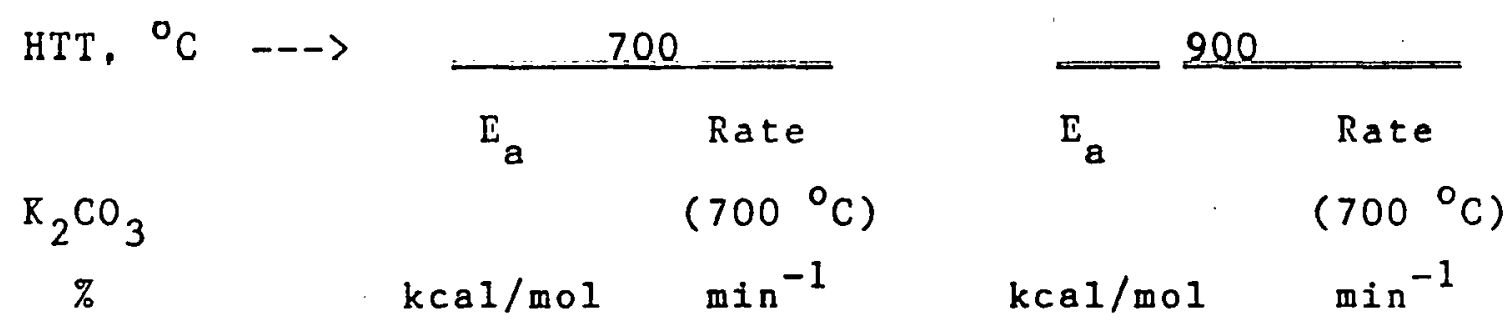

$\begin{array}{lllll}5 & 49 & 4.0 \times 10^{-4} & 51 & 1.2 \times 10^{-4} \\ 10 & 44 & 2.4 \times 10^{-3} & 43 & 1.8 \times 10^{-3} \\ 15 & & 37 & 1.8 \times 10^{-3} \\ 20 & 41 & 3.4 \times 10^{-3} & & \end{array}$


For $\mathrm{K}_{2} \mathrm{CO}_{3}$-catalyzed char gasification in stean at $700^{\circ} \mathrm{C}$, the table shows the effect of increasing the catalyst dose and also the detrimental effect on reactivity of high heat treatment temperatures in preparing the char.

Similar data are given for chars made from lignite, Pittsburgh seam coal and anthracite, and data are given for catalysis by all the alkali and alkaline earth metals. Interestingly, the order of effectiveness of the catalyst cations follows the periodic table.

Kosky et al. (1982), in an interim report on the preceding work, state that added catalyst efficacy decreases as rank decreases as follows:

$$
\text { graphite > anthracite > bituminous > lignite. }
$$

This is in line with the we1l-known fact that natural reactivity decreases as rank increases, making the relative effect of catalyst addition for low rank coals less than for higher rank coals.

Kosky et al. (1982) studied uncatalyzed chars, pre-catalyzed chars (catalyst applied prior to pyrolysis) and post-catalyzed chars. Cycling, i.e. repeated runs on the same char, was also investigated. In general, there was a progressive loss in catalytic activity in each cycle. This decrease is much more pronounced during steam gasification of the char than during gasiffcation in $\mathrm{CO}_{2}$. The authors' explanation of this phenomenon is that coal minerals act as scavengers of the catalyst salts. The time constant for scavenging reactions is of the order of one hour 
at gasification temperatures and should be considered whenever applicable. The study includes a wealth of quantitative rate information, and only some of the highlights are mentioned here:

(a) Anthracite:

The rate of $\mathrm{CO}_{2}$ gasification of Reading anthracites is verg low: $1.8 \times 10^{-6} \mathrm{~min}^{-1}$ at $700^{\circ} \mathrm{C}$ with an activation energg of $65 \mathrm{kcal} / \mathrm{mol}$. Bg contrast, Illinols \#6 uncatalyzed chars react at $2.6 \times 10^{-5} \mathrm{~min}^{-1}$ at $700^{\circ} \mathrm{C}$ and have an activation energy of $55 \mathrm{kcal} / \mathrm{mol}$. With $5 \% \mathrm{R}_{2} \mathrm{CO}_{3}$ pre-added, anthracite becomes quite reactive: $6.7 \times 10^{-4} \mathrm{~min}^{-1}$ at $700^{\circ} \mathrm{C}, \mathrm{E}_{\mathrm{a}}=40 \mathrm{kcal} / \mathrm{mol}$, even more reactive than $5 \% \mathrm{~K}_{2} \mathrm{CO}_{3}$-cataljzed Illinois \#6, which has a rate of $4 \times 10^{-4} \mathrm{~min}^{-1}, E_{a}=49 \mathrm{kcal} / \mathrm{mol}$.

(b) Illinois \#6 char:

No appreciable deactivation occurred as a result of cycling. The addition of $5 \% \mathrm{~K}_{2} \mathrm{CO}_{3}$ and $20 \% \mathrm{Na}_{2} \mathrm{CO}_{3}$ added after carbonization resulted in 10-40 fold increase in rate without much change in apparent activation energy. The main effect of the catalysts was to increase the pre-exponential factor of the kinetic equation, presumabig by increasing the density of the active sites on the char surface, as also pointed out by other authors.

(c) Pittsburgh coal char:

Char prepared from Pittsburgh high volatile A bituminous coal by carbonization at $700^{\circ} \mathrm{C}$ behaved similarly, 
although 1 t was somewhat less reactive than the IIIinois \# 6 col char. Addition of $5 \% \mathrm{~K}_{2} \mathrm{CO}_{3}$ resulted in an increase in reactivity of about an order of magnitude. There was also considerable catalyst deactivation on thermal cycling between $800{ }^{\circ} \mathrm{C}$ and room temperature.

(d) Lignite char:

Char prepared from North Dakota Iignite A coal by carbonization at $700^{\circ} \mathrm{C}$ exhibited $\mathrm{CO}_{2}$ gasification rates at $700^{\circ} \mathrm{C}$ that were about as fast as those exhibited by Illinols and Pittsburgh coal chars gasified at $800^{\circ} \mathrm{C}$. In the absence of catalysts, gasification rates at $800{ }^{\circ} \mathrm{C}$ were about 40 times as fast for lignite char as for Illinois \#6 char. Addition of alkali salt catalgsts resulted in a further increase in reactivity toward $\mathrm{CO}_{2}$, but the catalytic effect was less marked and less dependent on the composition of the catalyst than with the other chars.

Guzman and Wolf (1982) studied the $\mathrm{R}_{2} \mathrm{CO}_{3}$-catalyzed steam gasification of activated carbon and of Illinois \#6 coal char. They used catalyst loadings of $0 \%, 10 \%, 20 \%, 33.4 \%$ and $50 \%$ by weight of the activated carbon and coal. Carbon or coal particles having 120 micron diameters were impregnated with a $\mathrm{K}_{2} \mathrm{CO}_{3}$ solution containing the predetermined amount of salt to yield the desired loading prior to devolatilization. The amount of volatilized matter evolved during carbonizatin was about 6 to $8 \%$ for the activated carbon sample and about $38 \%$ for the coal. Particle size 
and steam flow rate were selected so that interphase and Intraphase mass and heat transport were not rate limiting. Under these conditions, the authors wrote the rate equation as:

$$
\text { rate }=k \text { a } p_{\mathrm{H} 20^{n}}
$$

where $k$ is a kinetic constant and a is the solid surface area per unit volume, and $n$ is an apparent reaction order. To relate a with porosity the authors used the grain model described by Calvelo and Cunningham (1970) and by Szekely and Evans (1970), which is a distributed version of the shrinking core mnitel referred to above [Sec. 2.1.2]. It envisions the solid as an array of regularly packed spheres all of the same size:

$$
a / a_{0}=\left[(1-\text { theta }) /\left(1-\text { thet } a_{0}\right)\right]^{2 / 3}
$$

where theta is the porosity and the subscript 0 refers to the initial condition. The carbon conversion $X$ is related to the porosity by

$$
X=1-[(1-\text { theta }) /(1-\text { theta } 0)]
$$

and the relationship between the reaction time and the conversion is:

$$
(1-x)^{1 / 3}=1-R t / 3
$$

where

$$
\mathrm{K}=\mathrm{b} \mathrm{p}_{\mathrm{H}_{2} \mathrm{O}}{ }^{\mathrm{n}} \mathrm{a}_{0} \mathrm{~A}_{\mathrm{c}} /\left(\left(\text { rho } \mathrm{c}_{\mathrm{c}}\left(1-\text { theta } \mathrm{a}_{0}\right)\right),\right.
$$

b is a stoichiometric coefficient defined by the relationship

$$
\mathrm{dC}_{\mathrm{C}} / \mathrm{dt}=-\mathrm{b} \mathrm{R}_{\mathrm{w}}
$$

in which $C_{c}$ are the moles of carbon per unit volume and $R_{\text {wis }}$ the rate of water consumpion per unit volume of solid, rho is the 
carbon true density and

$$
A_{c}=12.01=\text { atomic weight of carbon. }
$$

Guzman and Wolf found good agreement with these equations and calculated apparent activation energies of 62 and $58 \mathrm{kcal} / \mathrm{mol}$ respectively for activated carbon and for IIIinois \#6 coal char. They state that the activation energy of the uncatalyzed reaction was reported to be $85.3 \mathrm{kcal} / \mathrm{mol}$.

For coal, the gasification temperature range studied was from 695 to $800^{\circ} \mathrm{C}$. Without catalyst, the devolatilized activated carbon and coal samples did not exhibit more than $2 \%$ conversion after 30 minutes at $800^{\circ} \mathrm{C}$. With the catalyst, the rate peaked at $33.4 \% \mathrm{R}_{2} \mathrm{CO}_{3}$. At $50 \% \mathrm{R}_{2} \mathrm{CO}_{3}$ the conversion leveled off before reaching $50 \%$. The following initial rates were observed for Illinois \#6 coal char at a $33.4 \% \mathrm{~K}_{2} \mathrm{CO}_{3}$ loading:

$\because$ Temperature, ${ }^{\circ} \mathrm{C} \quad 695 \quad 720 \quad 750 \quad 775$

\begin{tabular}{lccccc}
\multicolumn{5}{c}{ Rate, min } \\
Illinois \#6 & 0.0029 & 0.014 & 0.026 & 0.044 & 0.070 \\
Activated Carbon & n.a. & 0.0027 & 0.0052 & 0.0125 & 0.022
\end{tabular}

The Illinois coal char is much more reactive.

Suzuki et a1. (1984) investigated the uncatalyzed and catalyzed reaction of two Japanese high volatile coals [Miike and Takashima], an Australian medium volatile coal and a Japanese lignite. The catalysts were sodium and potassium carbonates. They did not report rates, and it is not a very simple matter to estimate the rates from their reported data, although approximate rates can be calculated. The amount of catalyst used was $5 \%$ by 
weight, except for one run that employed $10 \%$ sodium carbonate. The rate of gasification of the high volatile coal Milke coal Increased by a factor of about 16 with the addition of $5 \% \mathrm{Na}$ or $R$ carbonate. The Takashima high volatile coal gave a similarly large increase. The authors attribute this to the softening and melting of these coals, which resulted in intimate mixing with the carbonates. The medium volatile Australian coal does not soften and melt, and the increase in gasification rate was only a factor of about 2. Thus it appears that alkali catalysts are fully effective only if thes are intimately mixed with the coal/char prior to sustained gasification. Addition of catalysts in the. filter may lead only to a marginal promotion of char gasification. Mims and Pabst (1980) studied the alkali-catalyzed gasification of char and found similar behavior and mechanism in the gasification with $\mathrm{CO}_{2}$ and with $\mathrm{H}_{2} \mathrm{O}$. They concluded that active potassium gasification sites are highly dispersed on the carbon substrate. They believed that $\mathrm{R}_{2} \mathrm{CO}_{3}$ reacts with the carbonaceous material to form groups at the edges of the carbon microlayers, and that this self-dispersion explains the consistency of their results with a wide range of meterials (I1linois coal char, Wyodak (washed) coal char, activated charcoal, spherocarb, spheron and polgfurfuryl alcohol coke). For all these materials, these authors found that the same rate coefficient applied at a given active $R / C$ atomic ratio, which is the $\mathrm{K} / \mathrm{C}$ atomic ratio after correction for the loss of potassium in reactions with mineral constituentis in. the coal. The mechanism postulated by these authors is the same as. 
the one used by Ergun [equations (2) and (3)], with the oxygen exchange reaction, eq. (2), at equilibrium and the surface oxide decomposition, eq. (3), the rate controling step. In the presence of hydrogen, this leads to the Langmulr-Hinshelwood rate equation:

$$
\text { rate }=k_{1} k_{2} C_{T} p_{H_{2}} /\left(k_{1} p_{H_{2}}+k_{-1} p_{H_{2}}+k_{2}\right)
$$

The term $k_{-1} \mathrm{p}_{2}$ dominates the denominator whenever a substantial amount of hydrogen is present, and under the assumption that this is indeed the case, Mims and Pabst simplified the rate equation. to:

or simply

$$
\text { rate }=\mathrm{k}_{1} \mathrm{k}_{2} \mathrm{C}_{\mathrm{T}} \quad \mathrm{P}_{\mathrm{H}_{2} \mathrm{O}} / \mathrm{p}_{\mathrm{H}_{2}} \text {. }
$$

$$
\text { rate }=k \mathrm{P}_{2} \mathrm{O}^{/ \mathrm{p}_{\mathrm{H}_{2}}}
$$

where $k$ is the rate coefficient, in min ${ }^{-1}$, and $C_{T}$ is the concentration of active sites, as previously defined. At $700{ }^{\circ} \mathrm{C}$ $\left(700^{\circ} \mathrm{F}\right.$ in text assumed to be a misprint)

$$
k=1.26 \times 10^{-3}[\mathrm{R} / \mathrm{C}]
$$

correlates all the rate coefficient data, in $\min ^{-1}$, as a function of $[R / C]$, the active $\mathrm{K} / \mathrm{C}$ atomic ratio. At a $1 / 1 \mathrm{H}_{2} 0 / \mathrm{H}_{2}$ ratio, this leads to the following gasification rates at a [R/C] ratio of $0.10:$

$$
\text { rate }=1.23 \times 10^{-3} \times 0.10 \times 1.0=1.23 \times 10^{-4} \mathrm{~min}^{-1}
$$

As the [K/C] ratio increases, a saturation point is reached, beyond which further catalyst loading results in no further increase in the gasification rate. By carbonizing the Illinois coal first and then adding potassium catalyst (either as ROH or $\mathrm{R}_{2} \mathrm{CO}_{3}$ ), saturation (defined as deviation from the linear rate 
relationsh1p) occurred at $[R / C]=0.05$, at which point the rate coefficient was approximately $0.0083 \mathrm{~min}^{-1}$. Complete saturation occurred very rapidly, and was complete at $[R / C]=0.1$, at which point the rate coefficient was $0.0089 \mathrm{~min}^{-1}$. When the I11inois coal was impregnated with a $\mathrm{K}_{2} \mathrm{CO}_{3}$ solution prior to carbonization, saturation occurred at approximately $[R / C]=0.1$ and the rate coefficient at saturation was about $0.017 \mathrm{~min}^{-1}$. When the coal was digested in concentrated $\mathrm{ROH}$ prior to carbonizing, the rate constant was linear up to $[R / C]=0.2$ and the rate coeffirient at saturation was $0.028 \mathrm{~m}^{-1} \mathrm{n}^{-1}$. Thus the method of treatment is an important variable in determining the number of active sites created by the catalyst. Treatment prior to carbonization is the most effective. Injection of catalyst into a filter is likely to be less effective. Mims and Pabst do not report the activation energy, hence rate calculations at higher temperatures are not possible from the information contained in this reference.

Sears et al. (1986) studied the effect of catalysts on the steam gasification rates of the chars of several low-rank coals. The coals were first devolatilized and catalyst was introduced to the resulting chars both by aqueous impregnation and by dry mixing. Preliminary TGA tests indicated that reactivity was not dependent on the catalyst addition technique, therefore only. drymix systems were used in the remainder of the tests. The following results were obtained: 
Initial gasification rate at $750^{\circ} \underline{C}$

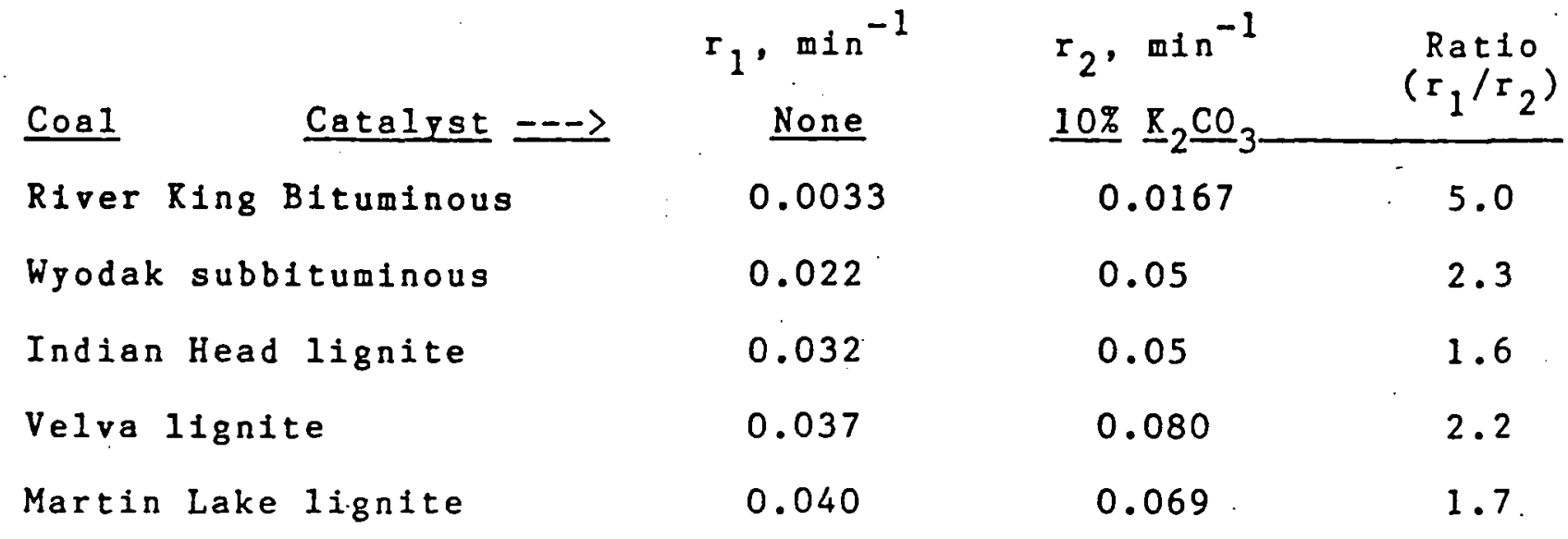

For Velva lignite, the authors compared the catalytic effectiveness of $20 \%$ sunflower Hull ash, recycled ash $\left(\mathrm{R}_{2} \mathrm{CO}_{3}\right.$-cat. gasification), $10 \% \mathrm{Na}_{2} \mathrm{CO}_{3}, 10 \% \mathrm{R}_{2} \mathrm{CO}_{3}, 10 \%$ Nahcolite, and $10 \%$ Trona. The effectiveness was found to be in the listed order, with sunflower hul1 ash the least and $10 \%$ Trona the most effective. The rate increase achieved by the addition of a catalyst is less dramatic with low rank coal chars than with higher rank ones, as : reported by numerous authors. The initial rates are as follows: Initial gasification rate of Velva L1gnite at $750^{\circ} \mathrm{C}$

$\begin{array}{lr}\operatorname{lin}^{-1} & \text { Ratio } \\ 0.037 & 1.00 \\ 0.045 & 1.21 \\ 0.050 & 1.35\end{array}$

$10 \% \mathrm{Na}_{2} \mathrm{CO}_{3}$ $0.067 \quad 1.81$
$10 \% \mathrm{~K}_{2} \mathrm{CO}_{3}$
0.080
2.16
$10 \%$ Nahcolite
0.10
2.70
$10 \%$ Trona
0.10
2.70 
As a function of temperature, Sears et al. provide the following information:

Temp., Gasification rate, min

\begin{tabular}{|c|c|c|c|c|c|}
\hline \multirow{3}{*}{ Coa 1} & \multirow[b]{2}{*}{ Catalyst } & \multirow[t]{2}{*}{${ }^{\circ} \mathrm{C}$} & \multirow{2}{*}{$\begin{array}{l}r_{1}, \min ^{-1} \\
\text { None }\end{array}$} & \multirow{2}{*}{$\begin{array}{c}\mathrm{r}_{2}, \mathrm{~min}^{-1} \\
10 \% \mathrm{~K}_{2} \underline{\mathrm{CO}}_{3}\end{array}$} & \multirow{2}{*}{$\begin{array}{l}\text { Ratio } \\
\left(r_{1} / r_{2}\right)\end{array}$} \\
\hline & & & & & \\
\hline & & 700 & 0.012 & 0.067 & 5.6 \\
\hline Wyodak & subbituminous & 750 & 0.020 & 0.087 & 4.3 \\
\hline & & 800 & 0.045 & 0.120 & 2.7 \\
\hline
\end{tabular}

$\begin{array}{llll}700 & 0.012 & 0.042 & 3.5\end{array}$

$\begin{array}{lllll}\text { Indian Head lignite } & 750 & 0.023 & 0.080 & 3.5\end{array}$

$\begin{array}{llll}800 & 0.042 & 0.097 & 2.3\end{array}$

$\begin{array}{llll}700 & 0.018 & 0.062 & 3.4\end{array}$

$\begin{array}{lllll}\text { Velva lignite } & 750 & 0.033 & 0.092 & 2.8\end{array}$

$\begin{array}{llll}800 & 0.063 & 0.112 & 1.8\end{array}$

$\begin{array}{llll}700 & 0.017 & 0.040 & 2.4\end{array}$

$\begin{array}{lllll}\text { Martin Lake lignite } & 750 & 0.032 & 0.077 & 2.4\end{array}$

$\begin{array}{llll}800 & 0.042 & 0.088 & 2.1\end{array}$

The relative rate increase due to catalysis is greatest at low temperature. As the temperature increases, the ratio between catalyzed and uncatalyzed reaction rates decreases. 
We have derived the least squares Arrhenius equations for these data and obtained the following parameters:

Uncatalyzed

Coal

type

$$
\text { Pre-exp. Activation }
$$

constant energy
Catalyzed

Pre-exp. Activation

constant energy
Wyodak

15,363

27,345

8,239

26,031

12,000

26,000

310

18,904

Indian Head

Velva

Martin Lake
33.8

12,082

384

17,535

310

Three of the four coals have similar uncatalyzed activation energies, and in all cases the decrease in the activation energy typical of catalysis is evident. The drop was very small for the Martin Lake lignite, but this coal also yielded greater deviations than the others in fitting the Arrhenius equation. Thus the uncatalyzed data for Martin Lake lignite are somewhat unusual.

Galegher et al. (1986) report the following activation energies:

$\mathrm{kcal} / \mathrm{mole}{ }^{\circ} \mathrm{C}$

Indian Head lignite char, uncatalyzed 28.8

$$
\begin{aligned}
& \mathrm{R}_{2} \mathrm{CO}_{3} \text { catalyzed } \\
& \mathrm{Na}_{2} \mathrm{CO}_{3} \text { catalyzed }
\end{aligned}
$$$$
18.4
$$

Velva lignite char, uncatalyzed 29.8

$$
\begin{aligned}
& \mathrm{R}_{2} \mathrm{CO}_{3} \text { catalyzed } \\
& \mathrm{Na}_{2} \mathrm{CO}_{3} \text { catalyzed } \\
& -47-
\end{aligned}
$$


Ternan and Sekhar (1985) studied the catalytic steam gasification bs $\mathrm{K}_{2} \mathrm{CO}_{3}$ of chars prepared from various sources, Including two Canadian coals: a Nova Scotia high volatile A bituminous coal ( $35.4 \%$ volatile matter, $2.4 \%$ ash) and an Alberta sub-bituminous $\mathrm{C}$ coal ( $37.8 \%$ volatile matter, $14.8 \%$ ash). Each material was mixed with 10 mass percent $\mathrm{R}_{2} \mathrm{CO}_{3}$ and pyrolyzed up to $900{ }^{\circ} \mathrm{C}$. The chars followed zero order gasification kinetics. The steam partial pressure is not given by the authors, but they state that a nitrogen stream saturated with water at room temperature was used. However, it appears that another nitrogen stream was also present, so that the partial pressures cannot be calculated from the available data. From a graph given in the paper, the following relationship is obtained for the char gasification at $900{ }^{\circ} \mathrm{C}:$

$$
\text { rate }=4.3 \times 10^{-4}+0.1(\mathrm{H} / \mathrm{C})
$$

where the rate is in $\operatorname{minn}^{-1}$, and $(H / C)$ is the atomic hydrogen/carbon ratio in the char. No data are available for other temperatures. The gasification of the sub-bituminous coal stopped at about $55 \%$ conversion and that of the bituminous coal at about $90 \%$ conversion.

Carraza et al. (1986) studied the steam gasification rates of graphite and of five different chars catalyzed by a mixture of potaosium and nickcl oxides below $1000 \mathrm{~K}$. In the case of Illinois \#6 coal char they found a synergistic effect: the rate of gasification in the presence of an equimolar mixture of nickel and potassium oxides the reaction rate exceeds the sum of the 
separately catalyzed rates, and there is a favorable effect on the life of the catalgst. In the case of the Montana subbituminous coal char, the rate is larger than with potassium alone but less than with nickel alone. In another report on the same work, Heinemann (1986) reports that, at $620^{\circ} \mathrm{C}$, the steam gasification of the Montana subbituminous coal char catalyzed by $K O H+N i O$ ( $R / N i=1.0$ molar, $R / C=1 \times 10^{-2}$ ) is several times as fast as with $R_{2} \mathrm{CO}_{3}$ catalysis $\left(R / C=1 \times 10^{-2}\right)$. The following average steady-state rates were obtained after one hour of steam gasification:

\section{$\underline{R}_{2}$ O/NiO-catalyzed Steam Gasification Rates}

\section{Material}

North Dakota Musky lignite char

Western Kentucky washed coal char

Illinois \#6 low temperature char

Il1inois \#6 high temperature char

Montana subbituminous coal char

Graphite

$$
\text { Rate, } \min ^{-1}
$$

0.0085

0.0071

0.0044

0.0036

0.0030

0.00042

Wood et al. (1985) studied the possibility of enhancing the activity of sodium chloride as a gasification catalyst, since its cost is much lower than that of alkali carbonates or hydroxides. They found however that the treatment of sodium chloride impregnated char in flowing steam produces onls a modest enhancement in gasification reactivity of Spheron 6 mineral-free carbon black and of IIIinois \#6 coal char. The use of carbon dioxide during the steam pretreatment enhances the catalytic 
activity in the case of the carbon black, but had little success with char from Illinois \#6 coal.

\subsubsection{Carbon-oxygen reaction}

Perlmutter (1983) impregnated char samples with sodium and potassium carbonates and concluded that a large portion of the catalyst added exists in interstices between chad particles withnut ifrert contact on the char surface and thus dues nut contribute to increased reactivity. He removed the inorganics between char particles by sieving and measured the amount of actual catalyst uptake by atomic absorption spectrophotometry. He also determined that the impregnated catalyst resides only on particle exteriors without penetrating into pore structures. This corroborates the general observations that extended catalyst treatment times have little effect on gasification rate and that the method of treating the char with catalyst, e.g. bulk mixing, ball milling, solution soaking or ion exchange, does not significantly alter gasification rate as long as a reasonable degree of mixing is achieved. These observations appear to hold at least for chars treated at room to moderate temperatures. $\mathrm{CO}_{2}$ adsorption measurements after impregnation showed that the adsorption capacities of the chars, and Lherefore the1r eurface areas, were not affected by the impregnation. It can beconcluded that the pore structure of the chars used in Perlmutter's study..: remained intact except for some blocking after the impregnation 
However this conclusion mag not always apply, as reported results are somewhat contradictory.

Because the catalyst does not penetrate the char pore volume, two distinct processes take place simultaneously when char particles are exposed to a reactant gas: a rapid reaction on the particle exterior, causing a decrease in particle size, and a slower non-catalytic reaction inside the particle on the pore surfaces. The rate of the catalgtic reaction is reported to be two orders of magnitude larger than that of the non-catalytic reaction, but because the outside area avallable to the catalyst is much less than the pore area, the non-catalytic reaction cannot be neglected in the general case. The observed overall gasification reaction is thus the sum of the catalptic and non-catalytic contributions.

The overall model involves three dimensionless parameters:

- the pore structure parameter, psi, defined previously in connection with the uncatalyzed carbon-oxygen reaction;

- a particle size parameter, sigma defined as:

$$
\text { sigma }=R_{0} S_{0} /(1-\text { epsilon })
$$

where,

$$
\begin{gathered}
\mathrm{R}_{0}=\text { the initial particle size, } \mathrm{m}, \\
\mathrm{S}_{0}=\text { initial surface area/unit volume, } \mathrm{m}^{2} / \mathrm{m}^{3} \\
\text { epsilon }=\text { initial porosity: } \\
\text { - a dimensionless time parameter defined as: } \\
\text { tau }=\mathrm{k}_{\mathrm{s}} \mathrm{C}_{0}^{\mathrm{n}} \mathrm{t} \mathrm{s}_{\mathrm{o}} /\left(1-\mathrm{epsilon_{0 }}\right)
\end{gathered}
$$


where

$$
\begin{aligned}
& k_{s}=\text { rate constant for char surface reaction, } \\
& C_{0}=\text { amblent concentration of gas reactant, } \\
& n=\text { reaction order relative to gaseous reactant, } \\
& t=\text { reaction time, sec. }
\end{aligned}
$$

The rate of the non-catalgzed reaction has been discussed in the corresponding section. The rate of change of the radius, $R$, of a spherical char particle in the catalyzed reaction is given by:

$$
d R / d t-k_{c} C_{0}^{m}
$$

The relative catalytic activity parameter, alpha, is the ratio of the enhanced intrinsic catalytic activity rate to the noncatalgtic rate:

$$
\text { alpha }=k_{c} C_{0}^{m / k_{s} C_{0}^{n}}
$$

If both catalytic and non-catalgtic reactions have the same orders of reaction $(m=n)$ then alpha is equivalent to the ratio of the catalytic to non-catalytic rate constants. The relative catalytic activity, alpha, may vary with conversion, but in the case of the chars studied by Perlmutter it remained relatively constant. When such is the case, the overall rate of change of the conversion, $X$, can be expressed as:

$$
\mathrm{dX} / \mathrm{dt}=(1-\mathrm{X})[1+\mathrm{ps} 1 * \mathrm{tau} / 2+3(\mathrm{a} 1 \mathrm{pha} / \mathrm{sigma}) /(1-\mathrm{a} 1 \mathrm{pha} * \mathrm{tau} / \mathrm{sigma})]
$$

The parameters psi and tau were defined earlier in connection with equation (13), and sigma is a particle size parameter defined as $R_{0} 3_{0} /\left(1-4 p 8110 n_{0}\right)$, where $R$ is the particle radiuo, S 13. the. surface area per unit volume, epsilon is the porosity, and: the: subscript o refers to the initial condition. 
Perlmuter found the actioation energies of the catalyzed reactions to be the same as those of the uncatalyzed reactions at the $90 \%$ confidence level. The type of catalyst (Na or $R$ ) and the catalyst concentration did not affect the activation energy of the intrinsic reactions regardless of the nature of the char (anthracite or bituminous coal). These observations indicate that the function of the catalyst is to increase the concentration of reactive sites on the char surface. It was further found that the ratios of the catalgtic to non-catalgtic rate constants correlate linearly with the catalgst surface concentration. If a mixed catalyst is used, the contributions of its various ingredients are aditive.

\subsection{DIFFUSIONAL RESISTANCES}

At the relatively low gasification temperatures covered by the work discussed above, the kinetics of the reactions are slow compared to diffusional effects, so that purely kinetic models such as the Langmuir-Hinshelwood model or the Ergun model gield results that are satisfactory from a practical point of view. As long as gasification is restricted to these low temperatures, more detailed models mag not be required. However, at temperatures above $1100^{\circ} \mathrm{C}$, the kinetics may be so fast that diffusional resistances become important and need to be considered. A number of models falling into two main categories have been developed to deal with this condition. One type of model considers the reaction 
to proceed on the surfaces of nonporous grains, the other type emphasizes the reaction Initiated on pore surfaces within the solid. In most cases, elther model includes enough parameters to represent the course of the reaction falrly well, and for most equipment design purposes either one mag be adequate. Further research will make it clearer when to use each type, and will. enable more precise calculations to be performed. The first type of models includes those of Szekely and Evano (1970) and of Calvelo and Smith (1971), who apply the shrinking core model to uniformly sized nonporous gratns of reacting solid. A property of such models is the prediction of a monotonically decreasing reaction rate because the area available for reaction continuously decreases. Gasification reactions however tend to exhibit a maximum reaction rate. Pore models overcome this limitation. As discussed above, Bhatia and Perlmutter (1980) developed a random pore model for fluid-solid reactions. Part I of their work covers an isothermal system with kinetic control. Part II (1981) adds diffusion and transport effects. The model gives a good fit to the gasification data of Hashimoto et al. (1979) in the kinetic regime. In certain cases where diffusion and transport effects are significant, pore closure may occur at the surface. In that event, there is an optimum reaction temperature which the model may help predict.

Yang (1984) studied the rate of steam gasification of a North Dakota lignite and of a Washington subbituminous coal and concluded that, at $1038^{\circ} \mathrm{C}$, diffusional effects were negliglbile: for 
particle sizes below 250 microns.

\subsection{CHARACTERISTICS AND REACTIVITY OF CHARS FROM PROCESSES}

An extensive study of the reactivity of chars collected in an actual gasification process, the Westinghouse Electric Corp./KRW Energy Systems Inc. process, were reported by Schmidt et al. (1983). Chars prepared in the laboratory as well as overhead fines from the Westinghouse/KRW ash-agglomerating, fluidized-bed reactor were collected in cyclones and subjected to standardized reactivity tests. The authors studied the effect of the maximum heat treatment temperature (HTT) and of the holding time at maximum HTT on the reactivity of chars prepared from a Wyoming subbituminous $C$ coal. Chars were prepared in a high temperature furnace with the aid of a gas mixture containing $7 \% \mathrm{H}_{2}$ and $93 \% \mathrm{~N}_{2}$. The tests were standardized by heating the coal to reactor temperature at $20^{\circ} \mathrm{C} / \mathrm{min}$, pyrolyzing at $1800{ }^{\circ} \mathrm{F}$ and $\mathrm{l}$ atm in 232 $\mathrm{ml} / \mathrm{min} \mathrm{N}_{2}$ and $18 \mathrm{~m} 1 / \mathrm{min} \mathrm{H}_{2}$, heat treating for the specified time at HTT and gasifying at $1800^{\circ} \mathrm{F}$ at $\mathrm{l}$ atm in a stream consisting of $100 \mathrm{ml} / \mathrm{min}$ steam, $50 \mathrm{ml} / \mathrm{min} \mathrm{H}_{2}$, and $150 \mathrm{ml} / \mathrm{min} \mathrm{N}_{2}$. The effect of HTT was studied with chars prepared at 1100,1200 and $1300{ }^{\circ} \mathrm{C}$, al 1 at a holding time of 1 sec. The effect of residence time was investigated by making an additional run at $1200^{\circ} \mathrm{C}$ at a 10 second holding time. An additional sample was prepared at $982^{\circ} \mathrm{C}$ in a thermogravimetric analyzer with the aid of the same gas mixture. The higher than usual HTTs were chosen because these were the 
temperatures considered likely in a commercial gasifier. The following results were obtained:

\begin{tabular}{|c|c|c|c|c|c|}
\hline Holding & Total area & Are. & gastfication & & eactivity \\
\hline tIme & & & rate & & Index \\
\hline sec & $\mathrm{m}^{2} / 8$ & & $\min ^{-1}$ & (coke & breeze=1) \\
\hline 1 & 48.2 & & .492 & & 164 \\
\hline 1 & 54.4 & & .516 & & 172 \\
\hline 10 & 50.9 & & .622 & & 208 \\
\hline 1 & 58.7 & & .494 & & 165 \\
\hline 1 & 37.8 & & .378 & & 126 \\
\hline
\end{tabular}

The 1 sec series showed no significant change in reactivity up to and including HTTs of $1200^{\circ} \mathrm{C}$. The $1300^{\circ} \mathrm{C}$ sample exhibited a substantial drop in reactivity. The sample held for 10 sec at the HTT temperature exhibited a $20 \%$ increase in reactivity with respect to the sample held for 1 sec. The sample with a HTT of $982^{\circ} \mathrm{C}$ differed from the other samples because of incomplece pyrolysis ( $38 \%$ volatile matter left vs. 4 to $12 \%$ for the other samples). The areas correlated with the reactivities except for the sample submitted to $10 \mathrm{sec}$ heat treatment, which would have been expected to have a larger area. This probably reflects the fact that the number of active sites rather than the surface area per se determine the reaction rate.

The same authors, Schmidt et al. (1984), characterized char fines collected in the RRW PDU primary cyclone with Wyoming subbituminous $C$ feedstock. An average relative; reactivitg of 15.2. (coke breeze $=1$ ) was obtained in four tests. The individual: 
results of these tests were $149,146,184$ and 130 . At a base reactivity of $0.003 \mathrm{~min}^{-1}$ for coke breeze, this translates into an average reactivity of $0.456 \mathrm{~min}^{-1}$. The authors concluded that, in the case of this Wyoming subbituminous coal, the reactivity of fines is essentially the same as for the larger size distribution. In a more recent and more extensive study, (Schmidt et al. (1986)), coal and/or char fines $(-120+140$ mesh $)$, from a number of coals processed in the RRW PDU were characterized for reactivity on a thermogravimetric analyzer (TGA). The TGA runs used char fines collected from the KRW PDU cyclone dip leg. Feedstock coals to the KRW PDU included Wyoming subbituminous $C$, Western Kentucky high volatile B bituminous, Republic of South Africa and Pittsburgh high volatile A bituminous coals. The tests were run by thermo-gravimetric analysis at $982^{\circ} \mathrm{C}, 1$ atm, in $33 \%$ steam, $17 \% \mathrm{H}_{2}$ and $50 \% \mathrm{~N}_{2}$. The results are summarized as follows: Reactivity of char fines from KRW PDU cyclone dip leg

$\begin{array}{lccc}\text { Coal Feedstock } & \text { Total area } & \text { Ave. reaction } & \text { Reactivity } \\ \text { to KRW/PDU } & \mathrm{m}^{2 / g} & \text { rate, min } & \text { (coke breeze=1) } \\ \text { Wyoming Sub-C } & 39.1 & .464 & 155 \\ \text { W. Kentucky hvBb } & \text { n.a. } & .020 & 6.8 \\ \text { Rep. S. Africa \#2 } & \text { n.a. } & .014 & 4.7 \\ \text { Pittsburgh hvAb } & \text { n.a. } & .0081 & 2.7 \\ \text { Coke breeze fines } & \text { n.a. } & .0025 & 0.75\end{array}$

The reactivity of the coke breeze fines is 0.75 when referred to the "standard" reaction rate of coke breeze of $0.003 \mathrm{~min}^{-1}$. By 
comparing these data to other results, the authors concluded that the reactivity of fines is nearly the same as that of larger size distributions, confirming the observations of Johnson and others that in the chemical-controlled regime the non-catalytic carbon conversion takes place throughout the particles, specifically in the micropores. The authors remind us that von Fredersdorff (1955) stated on the basis of a large number of studies that the carbon gasification reactions are chemlcally controlled below $1100^{\circ} \mathrm{C}$ for particle sizes normally used for gasification.

\subsection{COMMENTS ON LITERATURE SURVEY}

The literature on the gasification of char includes hundreds and perhaps thousands of articles. It is not the purpose of this task to provide a complete review of this subject, but rather to identify, evaluate and apply the material that could be helpful in dctcrmining the fcooibility of in-citu gaeification of char in a membrane filter. Thus the preceding literature surves, while thorough, is selective rather than exhaustive. Our emphasis is on evaluation and application. For this reason, we have emphasized actual rates over mechanisms, recognizing that the rates are more factual and mechanisms still somewhat speculative, and that the answers we need must be largely based on facts. This is not to minimize the importance of the efforts to elucidate mechanismsil: since from such efforts will come the understanding needed for 
generalization and major progress.

If then we focus on the rates, we are struck by the vast differences in reactiolties between chars made from coals of different rank. Lignite chars react orders of magnitude faster than high rank bituminous coal chars. Thus the coal feedstock is usually the most important single variable in determining the feastbility of gasifying a char. The process that produces the char is also important however, since high preparation temperatures lower the reactivity. The composition of the gas phase is another extremely important variable, and here there is a true shortage of useful information. Most investigators have focused on a single reaction at a time. Abundant data are available on the carbon-carbon dioxide reaction in an atmosphere of pure or nearly pure carbon dioxide or of carbon dioxide mixed with carbon monoxide, the carbon-steam reaction in the presence of steam or of steam mixed with some hydrogen, and the carbon hydrogen reaction in the presence of hydrogen only or of a mixture of hydrogen and methane. Very little work has been done to determine rates in the presence of a typical product gas from a commercial gasifier. The few studies reported on char gasification In mixed streams are confusing to say the least. McCoy et al. (1983) performed two sets of experiments with mixed gases in the presence of $\mathrm{K}_{2} \mathrm{CO}_{3}$ catalyst. They concluded that "gasification rate can be affected in a complex manner by reactant mixtures containing product gases" and that "a more complete set of experiments should be carried out if a complete analysis of the 
effects of gas constituents on the gasification rate is to be obtained".

\subsection{SUMMARY/EVALUATION OF LITERATURE DATA}

1. Char can be gasified by reaction with carbon dioxide, steam or hydrogen. The literature contains extensive data on the rate at which such reactions take place, and on possible mechanisms involved. The rates of the various reactions depend on gas composition, temperature, pressure and char characteristics, and on the presence or absence of catalysts.

2. In-place char gasification in a membrane filter is a definite possibility. (See discussion of chapter III and following). Numerous approaches are conceivable, the ultimate choice being a matter of plant/process economics. 'l'he actual evaluation of the economico is beyond the scope of this work.

The economics will depend on the gasification process, coal feed to the gasifier, and on many other process parameters.

3. Enough data are available so that, yiveñ a process and a coal, it is possible to postulate in-place gasification conditions and to develop preliminary estimates of the gasification rates. From these rates and other process data, preliminary economic evaluations can then be made. 
4. In the temperature range of $700^{\circ} \mathrm{C}$ to $1000^{\circ} \mathrm{C}$, the gasification reactions are largely under kinetic control. Under these conditions, reaction rates generally follow a

Langmuir-Rinshelwood type of equation. The reactions that take place depend on pressure and temperature. At low pressure, little if any methane is formed, and the products are carbon monoxide and hydrogen. These reaction products have a large retarding effect on the rate of reaction. The literature contains much more information on reaction rates in the absence of these reaction products than in their presence. Nevertheless approximate rate calculations should be possible at temperatures where kinetic control prevalls.

5. Because of the retarding effect of the reaction products, it is doubtful if major extent of char conversion can be achieved in the filter in the presence of the gases exiting the gasifier, and at the temperature of those gases. However, estimates can and should be made in each specific case to verify this conclusion.

6. The type of coal used in the gasifier is probably the single largest variable involved in char gasification. The rate of gasification varies dramatically with coal rank. Lignites and subbltuminous coals are much more reactive than bituminous coals, and anthracites are even less reactive. These coal reactivities carry over to the chars made from these coals. 
7. The range of the gasification. rates tends to be reduced in the case of catalytic gasification, as naturally highly reactive lignites benefit less from the addition of catalyst than bituminous coals.

8. Char gasification is a rate process that requires a significant time at the proper conditions. In-place gasification in the membrane filter will have to be carefully designed, so that the gas composition, temperature, pressure and other factors are favorable to the desired result.

9. The average particle trapped on a filter may wcll be less reactive than the average char particle exiting an upstream gasifier due to the longer holding time of the filter char. Further, since the char on filters will already have been partially gasified, it may well be past the point on the reactivity versus conversion chart where reactivily is at a maximum. However, the rates cited in this report are generally initial rates rather than maximum rates.

10. It seems that all the papers included in this review have rontained the tacit assumption that a char particle is essentially uniform in compusition. Given the will known heterogeneity of coal on both the macroscopic and microscopic. scales, we believe that such an assumption is not a good.. one: The decline in reactivity at advanced conversion levels noted 
in this review could be caused, at least partially, simply by gasification reactions having consumed the easier gasified portions of the char particles, leaving only the less reactive portions as reactant. If this phenomenon is true, the char remaining on filters may be the most refractory part of the original coal, and nearly impractical to gasify. 


\section{HYPOTHESIZED METHODS}

The problem addressed by this task is one which, if solved successfully, should enhance process efficiency and ease of operation. Solutions that do not alter gasifier or cleanup train operation in a major way are likely to be the best candidates. Hypothesized methods are analyzed in Chapter IV.

\subsection{IN-PLACE GASIFICATION IN THE MEMBRANE FILTER}

This item covers in-place gasification of a portion of the char in the membrane filter, by reaction with an appropriate gas stream. Some of the possibilities include:

\subsubsection{Fasification by Normal Gas Stream}

The term "normal gas stream" refers to the gas stream that normally flows through lle membrane filtar(e).

\subsubsection{As-is Normal Gas Stream \\ (Hypullesis 1 )}

The "as-is normal process gas stream" is the gas stream that normally flows through the membrane filter(s) without any changes in composition, temperature or pressure. Char gasification by: reaction with this stream would be the gimplest possible solution. For each process and coal, the first step is an evaluation: of: the 
expected gasification rate at the prevaling gas composition, temperature and pressure. In general, the char gasification rate obtained under these coñditions will not be large enough to be significant:

\subsubsection{Hotter Normal Gas Stream}

(Hypothesis 2)

Enhancement of the gasification rate in the membrane filter may be achieved by increasing the temperature in the filter, e.g. by doing less cooling or quenching ahead of the membrane filter.

\subsubsection{Normal Gas Stream plus Catalyst}

(Hypothesis 3)

Enhancement of the gasification rate in the filter by i. injection of a catalytic material. This approach is subject first to a thermodynamic evaluation, to make sure that there is no thermodynamic impediment to gasification. In general, it is likely. that the limitation will be kinetic in nature, and chat a major problem will be to achieve a good distribution of the catalyst on the char surface. Literature data show that this will not be an easy task. The catalyst must coat the outer surface of the char particles where the catalytic reaction takes place. The micropore network inside the particles does not appear to be available for catalytic reaction. Ang catalyst deposited in the interstitial 
space between particles will be wasted.

Given the large increase in rates cited in the literature, this approach would appear to warrant some research.

\subsubsection{Hotter Normal Gas Stream plus Catalyst} (Hypothesis 4)

The combination of reduced quenching plus the injection of catalyst may be an attractive combination. The higher temperature is meant to ensure a thermodynamic driving force for gasification, while the addition of catalyst might increase the rate of gasification to a practical value.

\subsubsection{Gasification by Gas Other than Normal Stream}

Enhancement of the gasification rate in the membiane filter by changing the composition of the gas. This could be achieved in several ways:

$$
\begin{aligned}
3.1 .2 .1 & \text { Carbon Vioxide } \\
& \text { (Hypothesis } 5) \\
3.1 .2 .2 \quad \text { Steam } & \text { (Hypothesis } 6)
\end{aligned}
$$

These methods would be most applicable to large plants with several parallel strings of filters. Each filter is switched $\because$ 
off-stream in turn so that one of the filters would be off-stream at all times and would be fed with steam and/or $\mathrm{CO}_{2}$ to gasify most of the char prior to discharge.

\subsubsection{2 $\mathrm{H}_{2} \mathrm{O}$ Injection into Normal Gas Stream} (Hypothesis 7)

In situations where the product could tolerate it, injection of additional gas, e.g. steam, at an appropriate temperature, during part of the filtration cycle.

\subsubsection{In-place Combustion}

(Hypothesis 8 )

In-place combustion of the char in the membrane filter. The advantage of combustion over gasification is the much higher rate of reaction at a given temperature. Disadvantages include the need to solve complex safety issues and to design the filter to withstand elevated local temperatures. Nevertheless, this approach may be feasible in a multi-string plant, where one spare filter would be regenerated from time to time by reaction with air, following purging with nitrogen.

\subsubsection{Catalyzed in-place combustion}

(Hypothesis 9) 
At a given temperature higher rates could be achieved, or a lower temperature could be used to achieve the same rate. Same safetg and process design problems as for preceding case.

\subsection{INCREASED CHAR RESIDENCE TIME IN THE FILTER \\ (Hypothesis 10)}

Increasing the char residence time on the filter. either alone or in combination with one of the gasification enhancement methods discussed under item 3.1 .

\subsection{REMOVAL OF CHAR FROM FILTER FOLLOWED BY CHAR PROCESSING}

(Hypothesis 11)

This option covers removal of the char from the filter followed by reduction of its volume through gasification or combustion, either catalyzed or uncatalyzed. Once the char has beon romoved from the filtor, combuotion becomos a much more viable possibility.

\subsection{INCREASE IN PRESSURE OF FILTER}

(Hypothesis 12)

Increasing the pressure in the filter, either alone or in: conjunction with one of the gasification enhancement methods discussed in 3.1 and 3.2 . 
IV. EVALUATION OF HYPOTHESIZED METHODS

\subsection{IN-PLACE GASIFICATION IN MEMBRANE FILTER}

\subsubsection{Gasification by Normal Gas Stream}

\subsubsection{Fluidized Bed Processes}

Schmidt et al. (1983, 1984) reported heat and material balances for a series of single-stage oxygen-blown tests made in the KRW PDU. The features of most direct interest for this study are:

- the operating conditions in the fluidized bed reactor, since these determine the characteristics of the char leaving the reactor

- the temperature, pressure and composition of the gas stream leaving the second of two cyclones in series, since that stream would enter the membrane filter.

Schmidt et al. (1983, 1984) give data on tests TP-034-2 and TP-035-1 with Wyoming Sub-C coal as the feedstock. Both tests were made to study the recycling of fines from the cyclones. The test conditions are listed below. 
RRW PDU Operating Data

Test No. - - >

Gasifier freeboard temperature, ${ }^{\circ} \mathrm{C}$

Gasifier bed temperature, ${ }^{\circ} \mathrm{C}$

System pressure, atm

Gas stream from cyclone \#2:

Temperature, ${ }^{\circ} \mathrm{C}$

Gas composition, \% by rolume:

$\begin{array}{rrr}\mathrm{CO} & 30.85 & 33.28 \\ \mathrm{CO}_{2} & 26.28 & 29.27 \\ \mathrm{H}_{2} & 12.80 & 22.08 \\ \mathrm{CH}_{4} & 1.33 & 4.79 \\ \mathrm{~N}_{2} & 0.46 & 0.37 \\ \mathrm{O}_{2} & 0.00 & 0.00 \\ \mathrm{H}_{2} \mathrm{O} & 27.38 & 10.05\end{array}$

The above figures are averages of 6 samples for test I'P-U34-2 and of 7 samples for test TP-035-1, and may be interpreted to be the composition, temperature and pressure of the process gas stream that would normally flow through the membrane filter.

\subsection{Thermodynamic Considerations}

To determine the feasibility of various gasification reactions in the membrane filter by reaction with components of the normal gas stream, the free energy changes and equilibrium. constants are calculated below for the various possible 
gasification reactions. The pseudo-equilibrium constant, i.e. the observed ratio of product concentration to reactant concentration, each raised to the approprlate power as indicated by the reaction stoichiometry, is also calculated from the gas compositions for each reaction, and compared to the theoretical equilibrium constant to determine if the reaction is feasible. The calculations were made at the conditions of the two RRW fluldized bed PDU runs described above, with the focus on the conditions prevalifing at the exit of the second cyclone, the logical location of the membrane filters. In addition, the effect of higher temperatures achieved by eliminating quenching at the reactor outlet is examined. The free energy changes for these calculations were obtained from the JANAF Thermochemical Tables.

$$
\mathrm{C}-\mathrm{CO}_{2} \text { Reaction }
$$

For the reaction

$$
\mathrm{C}+\mathrm{CO}_{2} \quad \Leftrightarrow==2 \mathrm{CO}
$$

the free energy change is:

$$
\begin{aligned}
& \text { at } 1000 \mathrm{~K}: \operatorname{deltaF}^{\circ}=2 *(-47859)+94628=-1090 \mathrm{cal} / \mathrm{gmol} \mathrm{C} \text { or } \mathrm{CO}_{2} \\
& \text { at } 1100 \mathrm{R}: \operatorname{deltaF}^{\circ}=2 *(-49962)+94658=-5266 \mathrm{cal} / \mathrm{gmol} \mathrm{C} \text { or } \mathrm{CO}_{2}
\end{aligned}
$$

and by interpolation, for run TP-034-1, for the gas leaving the cyclone at $1013 \mathrm{~K}$ :

$$
\begin{aligned}
\operatorname{de} 1 \mathrm{taF}^{0} & =-1090-.13(5266-1090)=-1633 \mathrm{cal} \\
1 \mathrm{n} R & =1633 /(1.99 * 1013)=0.810 \\
\mathrm{~K} & =\exp [0.810]=2.25
\end{aligned}
$$




$$
{ }^{2} \mathrm{P}_{\mathrm{CO}} / \mathrm{P}_{\mathrm{CO}}=0.3085 * 0.3085 * 16.7 / .2628=6.05 \text { (observed) }
$$

For the particular composition of RRW PDU test TP-034-2, the gas leaving the cyclone contains more co than would be dictated by equilibrium, hence the carbon-carbon dioxide reaction cannot take place at this temperature under hypothesis 1 , in which the gas normally flowing through the filter is the reactant.

In test TP-035-1 the gas leaves the second cyclone at $1022 \mathrm{~K}$ :

$$
\begin{aligned}
& \text { deltaF }{ }^{\circ}=-1090-.22(5266-1090)=-2009 \mathrm{cal} \\
& \text { In } R=2009 /(1.99 * 1022)=0.988 \\
& R-\exp (0.988)=2.69 \\
& 2 \\
& { }^{\mathrm{P}} \mathrm{CO} / \mathrm{P}_{\mathrm{CO}_{2}}=.3328 * .3328 * 16.3 / .2927=6.17 \text { (observed) }
\end{aligned}
$$

As in the preceding case, the thermodyramics do not favor further gasification by $\mathrm{CO}_{2}$ under hypothesis 1.

The reactor bed temperature for test TP-34-2 was $1006^{\circ} \mathrm{C}$, i.e. $1279 \mathrm{~K}$, at which temperature the equilibrium constant is calculated by interpolation:

$$
\begin{array}{ll}
\text { at } 1200 \mathrm{R}: & \operatorname{deltaF^{0}}=2 *(-52049)+94681=-9417 \mathrm{cal} \\
\text { at } 1300 \mathrm{R}: & \operatorname{deltaF^{\circ }}=2 *(-54126)+94701=-13551 \mathrm{cal}
\end{array}
$$

hence at $1279 \mathrm{R}: \operatorname{deltaF^{\circ }}=-9417-.79(1.3551-941.7)=-12683 \mathrm{cal}$

$$
\begin{aligned}
\ln K & =12683 /(1.99 * 1279)=4.983 \\
K & =\exp [4.983]=146
\end{aligned}
$$

As expected, conditions in the reactor favor $\mathrm{CO}_{2}$ gasification. thermodynamically but the drop in temperature between the reactor and the cyclone reverses the situation. Much of the temperatures drop is caused by. the injection of quench water into the gasifier " exit gas stream, and some is due to heat losses. Heat 1osses: 
would be smaller in a commerclal plant than in the PDU; hence the situation would be somewhat more favorable there.

It is concluded that char gasification by the $\mathrm{CO}_{2}$ contained in the gas stream normally flowing through the membrane filter is not feasible after quenching, but could have merit at a higher temperature (hypothesis 2) and needs to be examined from a kinetic point of view.

$$
\mathrm{C}-\mathrm{H}_{2} \mathrm{O} \text { Reaction }
$$

For the stear gasification reaction

$$
\mathrm{C}+\mathrm{H}_{2} \mathrm{O}<===\mathrm{CO}+\mathrm{H}_{2}
$$

the free energy change is:

$$
\begin{aligned}
& \text { at } 1000 \mathrm{~K}: \quad \operatorname{de} 1 \mathrm{taF}^{\circ}=-47859+46040=-1819 \mathrm{ca} \\
& \text { at } 1100 \mathrm{R}: \quad \mathrm{deltaF}=-49962+44712=-5250 \mathrm{cal}
\end{aligned}
$$

and by interpolation:

$$
\begin{aligned}
\text { at } 1013 \mathrm{R} & : \operatorname{deltaF}=-1819-.13(5250-1819)=-2265 \mathrm{cal} \\
\operatorname{In} \mathrm{R} & =2265 /(1.99 * 1013)=1.124 \\
\mathrm{~K} & =\exp [1.124]=3.08 \\
\mathrm{P}_{\mathrm{CO}} \times \mathrm{P}_{2} / \mathrm{P}_{2} \mathrm{O} & =0.3085 * 0.1280 * 16.7 / .2738=2.41 \text { (observed) }
\end{aligned}
$$

In this instance (hypothesis 1) the thermodynamics favor steam gasification, but only marginally.

A similar calculation for run TP-035-1 pields the following results:

at $1022 \mathrm{~K}: \operatorname{de} 1 \mathrm{taF} \mathrm{F}^{0}=-1819-.22(5250-1819)=-2574 \mathrm{cal}$

$\ln R=2574 /(1.99 * 1022)=1.266$

$$
R=\exp (1.266)=3.55
$$




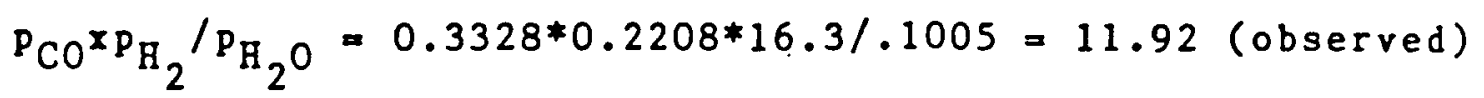

This test was run at a much lower temperature than test TP-034-2 and no quench water was used at the reactor outlet. Consequentig the percentage of water vapor in the gas was much lower than in test TP-034-2 and the thermodynamics are very unfavorable for steam gasification.

It is concluded that steam gasification of the char by the normal gao otream in the membrane filters (hypothesis 1) does not look promising, but would be alded by higher temperatures at the exit of the cyclones (hypothesis 2 ), 1.e. by a relatively high operating temperature in the reactor, and 1ittle or no quenching. Unfortunately the reduction of quenching also decreases the concentration of water vapor in the gas phase, which has a negative effect on both equilibria and rate of steam gasification. From the literature survey, we know that the presence of $\mathrm{CO}$ and $\mathrm{H}_{2}$ promotes reverse reaction (2) and reverse reaction (16), which regenerate free sites on the carbon surface and thereby slow down gasification.

$$
\mathrm{C}-\mathrm{H}_{2} \text { Reaction }
$$

For the methane formation reaction

$$
\mathrm{C}+2 \mathrm{H}_{2}\left\langle=\Rightarrow \mathrm{CH}_{4}\right.
$$

we obtain the following results (Test TP-34-2):

$$
\begin{array}{ll}
\text { at 1000R: } & \operatorname{deltaF}=4625 \\
\text { at 1100R: } & \operatorname{deltaF}=7247
\end{array}
$$


and by interpolation for the gas leaving the cyclone:

at $1013 \mathrm{R}: \operatorname{deltaF}{ }^{\circ}=4625+.13(7247-4625)=4966$

$$
\begin{aligned}
\ln \mathrm{R} & =-4966 /(1.99 * 1013)=-2.463 \\
\mathrm{~K} & =\exp [-2.463]=0.085 \\
\mathrm{P}_{\mathrm{CH}_{4}} /\left(\mathrm{p}_{\mathrm{H}_{2}}\right)^{2} & =0.0133 /(.1280 \times .1280 \times 16.7)=0.049 \text { (observed) }
\end{aligned}
$$

Similarly for the gas leaving the cyclone in run TP-035-1:

at $1022 \mathrm{R}: \operatorname{deltaF}=4625+.22(7247-4625)=5202$

$$
\begin{aligned}
\cdot \operatorname{In} \mathrm{K} & =-5202 /(1.99 * 1022)=-2.558 \\
\mathrm{R} & =\exp [-2.558]=0.077 \\
\mathrm{p}_{\mathrm{CH}_{4}} /\left(\mathrm{p}_{\mathrm{H}_{2}}\right)^{2} & =0.0469 /(.2208 * .2208 * 16.3)=0.059 \text { (observed) }
\end{aligned}
$$

In both runs the pseudo-equilibrium constant is less than the equilibrium constant indicating that the $\mathrm{C}-\mathrm{H}_{2}$ reaction can take place in the membrane filter, but the small theoretical

equilibrium constant indicates that the reaction is of little significance. Can significant methane be formed in the reactor via the $\mathrm{C}-\mathrm{H}_{2}$ reaction? The reactor bed temperature for test TP-34-2 was $1006^{\circ} \mathrm{C}$, i.e. $1279 \mathrm{~K}$, and the equilibrium constant is calculated by interpolation as follows:

$$
\begin{aligned}
& \text { at 1200R: } \operatorname{deltaF^{\circ }}=9887 \mathrm{cal} / \mathrm{mole} \\
& \text { at 1300R: deltar } \mathrm{F}^{\circ}=12535 \mathrm{cal} / \text { wule }
\end{aligned}
$$

hence at $1279 \mathrm{~K}:$ deltaF ${ }^{\circ}=9887+.79(12535-9887)=11979$

$$
\begin{aligned}
& \ln R=-11979 /(1.99 * 1279)=-4.706 \\
& \quad R=\exp [-4.706]=0.0090 \\
& { }_{{ }_{C H}} /\left(p_{H_{2}}\right)^{2}=0.0161 /(.1544 * .1544 * 16.7)=0.041 \\
& \text { (pseudo-equilibrium observed prior to quenching) }
\end{aligned}
$$


Thus, the temperature in the reactor is unfavorable to the formation of significant methane by direct hydrogenation. The methane observed in excess of the amount predicted by theoretical equilibrium for the $\mathrm{C}-\mathrm{H}_{2}$ reaction is probably due to coal pyrolysis and cracking of coal volatiles.

$$
\mathrm{C}-\mathrm{H}_{2}-\mathrm{H}_{2} \mathrm{O} \text { Reaction }
$$

For the reartion

$$
2 \mathrm{C}+\mathrm{H}_{2}+\mathrm{H}_{2} \mathrm{O}<===>\mathrm{CO}+\mathrm{CH}_{4}
$$

we obtain the following results (run TP-34-2):

$$
\begin{array}{ll}
\text { at } 1000 \mathrm{R}: & \operatorname{deltaF^{\circ }}=-47859+4625+46040=2806 \mathrm{cal} \\
\text { at } 1100 \mathrm{R}: & \operatorname{deltaF^{\circ }}=-49962+7247+44712=1997 \mathrm{cal}
\end{array}
$$

and by interpolation for the gas leaving the cyclone:

$$
\begin{aligned}
& \text { at } 1013 \mathrm{~K}: \operatorname{de} 1 \mathrm{taF}^{0}=2806-.13(2806-1997)=2701 \\
& \text { In } R=-2701 /(1.99 * 1013)=1.340 \\
& R=\exp [-1.340]=0.262
\end{aligned}
$$

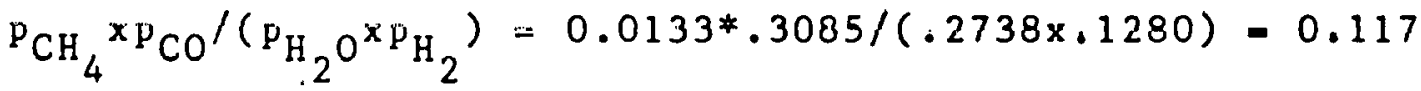

Thus the $\mathrm{C}-\mathrm{H}_{2}-\mathrm{H}_{2} \mathrm{O}$ reaction is thermodynamically feasible in the membrane filter, but the small theoretical equilibrium constant indicates that its significance is small.

At the reactor bed temperature for test TP-34-2 of $1006^{\circ} \mathrm{C}$ (1279R), the equilibrium constant is calculated by interpolation as follows:

$$
\begin{aligned}
& \text { at 1200R: deltaF }{ }^{\circ}=-52049+9887+43371=1209 \mathrm{cal} \\
& \text { at } 1300 \mathrm{R}: \operatorname{de} 1 \mathrm{taF} \mathrm{F}^{\circ}=-54126+12535+42022=431 \text { cal: }
\end{aligned}
$$


hence at $1279 \mathrm{R}: \operatorname{deltaF}^{\circ}=1209+.79(1209-431)=2827$

$$
\begin{aligned}
\ln R & =-2827 /(1.99 * 1279)=-1.108 \\
R & =\exp [-1.108]=0.330
\end{aligned}
$$

Actual pseudo-equilibrium composition before quenching:

$$
\mathrm{P}_{\mathrm{CH}_{4}} \times \mathrm{P}_{\mathrm{CO}} /\left(\mathrm{P}_{\mathrm{H}_{2}} \mathrm{O}^{\left.\times \mathrm{P}_{\mathrm{H}_{2}}\right)=0.0161 * .3896 /(.1261 \times .1544)=0.322}\right.
$$

Thus the reaction is essentially at equilibrium in the fluidized reactor in this particular test.

The reader may have noticed that the $\mathrm{C}-\mathrm{H}_{2}-\mathrm{H}_{2} \mathrm{O}$ reaction is actually the sum of the $\mathrm{C}-\mathrm{H}_{2} \mathrm{O}$ and of the $\mathrm{C}-\mathrm{H}_{2}$ reactions, and thus is not an independent reaction. Surprisingly, the model of Johnson (1982) assumes that, in gas mixtures containing hydrogen and steam, these three reversible reactions occur independently of one another.

\section{Summary - al1 Reactions}

The thermodynamic calculations for all four gasification reactions indicate little or no driving force for further gasification in the membrane filter by the gas normally leaving the cyclones under the KRW PDU conditions (temperature 740 to $750^{\circ} \mathrm{C}$ ). Thus hypothesis 1 does not appear viable at those temperatures. 
Hotter Normal Gas Stream (Hypothesis 2)

The thermodynamic calculations also indicate that large driving forces exist for the $\mathrm{C}-\mathrm{CO}_{2}$ and $\mathrm{C}-\mathrm{H}_{2} \mathrm{O}$ reactions at temperatures in the range of $1000^{\circ} \mathrm{C}$. Such temperatures can be achieved by eliminating or reducing quenching and heat losses. Since heat losses in commercial units are always smaller than in pilot plants, this factor is favorable.

Addition of Catalyst (Hypothesis 3 )

To the extent that thermodynamics is the limiting factor, the addition of a catalyst is of course fruitless. However, at higher temperatures where the thermodynamics are favorable to char gasification, the addition of a catalyst (hypothesis 3 ) might help overcome the unfavorable influence of a gas with 1 arge $\mathrm{CO}^{\circ} \mathrm{CO}_{2}$ and $\mathrm{H}_{2} / \mathrm{H}_{2} \mathrm{O}$ ratios.

\subsection{Rinetic Considerations}

\section{As-is Normal Gas Stream (Hypothesis 1)}

From the data of Taylor and Bowen (1976) the gasificiation rate of a subbituminous coal char in pure $\mathrm{CO}_{2}$ at 1 atm. and $74.0^{\circ} \mathrm{C}$ is 0.0085 minute ${ }^{-1}$. In the case of run TP-034-2 the partial: pressure of $\mathrm{CO}_{2}$ is $16.7 \times .263=4.4$ atm, hence on the basis of 
Langmuir-Hinshelwood kinetics the rate would be 0.037 per min in pure $\mathrm{CO}_{2}$. In the presence of $\mathrm{CO}$ the rate is slowed down considerably, without even considering the effect of the other gases. Thus the rate of gasification of subbituminous coal char by $\mathrm{CO}_{2}$ in a filter following the $\mathrm{KRW}$ PDU cyclones may be estimated to be of the order of 0.01 minute ${ }^{-1}$, assuming thermodynamics favored the reaction.

Most kinetic studies of char gasification have focused on a single reaction at a time, in part because a principal aim of most investigators was to elucidate mechanisms. A notable exception is the work of Johnson (1982) who developed empirical correlations to describe differential coal char gasification rates, based on results obtained from several hundred tests in a thermobalance apparatus. Numerical evaluations of the kinetic parameters were obtained from results obtained with a variety of bituminous coal chars gasified in $\mathrm{H}_{2}-\mathrm{CH}_{4}, \mathrm{H}_{2}-\mathrm{H}_{2} \mathrm{O}$, and $\mathrm{CO}-\mathrm{CO}_{2}-\mathrm{H}_{2}-\mathrm{H}_{2} \mathrm{O}-\mathrm{CH}_{4}$ mixtures at temperatures from 800 to $1100^{\circ} \mathrm{C}$ and total pressures from 1 to 70 atm. Johnson's model assumes that in gas mixtures containing hydrogen and steam, three reversible reactions occur independently of one another.

$$
\begin{aligned}
& \mathrm{C}+\mathrm{H}_{2} \mathrm{O}<==\Rightarrow \mathrm{CO}+\mathrm{H}_{2} \\
& \mathrm{C}+2 \mathrm{H}_{2} \longleftrightarrow==\Rightarrow \mathrm{CH}_{4} \\
& 2 \mathrm{C}+\mathrm{H}_{2}+\mathrm{H}_{2} \mathrm{O}<==\Rightarrow \mathrm{CO}+\mathrm{CH}_{4}
\end{aligned}
$$

(As previously pointed out, reaction [III] is the sum of reactions [I] and [II], and is therefore not an independent reaction.) 
Johnson further assumes that gasification by the carbon-carbon dioxide reaction is negligible under the conditions considered, and that carbon dioxide interacts only in the water-gas shift reaction $\left(\mathrm{CO}+\mathrm{H}_{2} \mathrm{O} \Leftrightarrow=\Rightarrow \mathrm{CO}_{2}+\mathrm{H}_{2}\right)$.

The total carbon conversion rate in Johnson's model is described by the expression:

$$
\text { rate }=\mathrm{dX} / \mathrm{dt}=\mathrm{f}_{\mathrm{L}} \mathrm{k}_{\mathrm{T}}(1-\mathrm{X})^{2 / 3} \exp \left[-(\text { alpha }) \mathrm{X}^{2}\right]
$$

where $X$ is the fractional conversion, $f_{L}$ is the relative reactivity factor defined as

$$
f_{L}=f_{L}^{0} \exp -\left[(9340 / R)\left(1 / T-1 / T_{p}\right)\right]
$$

which depends on the coal type and char pretreatment temperature $\mathrm{T}_{\mathrm{p}} ; \mathrm{f}_{\mathrm{L}}{ }^{\circ}$ is a reactivity factor which depends on the coal, $\mathrm{R}$ is the gas constant, $T$ is the absolute temperature, and alpha and $k_{T}$ are kinetic parameters defined below.

Johnson correlated $f_{L}{ }^{\circ}$ with the rank of the coal:

$$
f_{L}{ }^{0}=6.2 Y(1-Y) \quad \text { for } \quad 0.67 \leq Y \leq 0.93
$$

wherc $Y$ ic the weight frartion carbon in the raw coal (m.a.t.).

Typical carbon contents of some important coals reported by Margrave and Hauge (1984) are as follows (in \%, m.a.f.):

$\begin{array}{lcccc}\text { Texas } & \text { Wyodak } & \text { Rawhide } & \text { Illinois \#6 } & \text { Plllsuigh } \\ \text { Lignite } & \text { Subbil. } & \text { Subbit. } & \text { Bituminous } & \text { Bituminous } \\ 75.0 & 72.5 & 74.8 & 78.2 & 84.0\end{array}$

The total rate constant $k_{T}$ is the sum of the rate constants

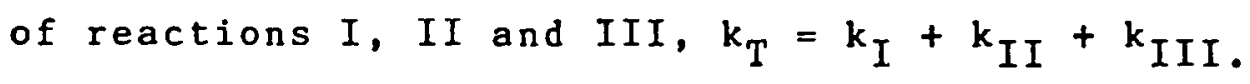
The kinetic constants $k_{I}, k_{I I}, k_{1 \perp I}$ and alpha are defined by Johnson's equations $(23.186),(23.187),(23.188)$ and $(23.189)$; 
respectively in Elliott's second supplementary volume to the Chemistry of Coal Utilization. These complex equations are not reproduced here. However, the equations have been programmed and run for the conditions of the RRW PDU runs, which used Wyoming sub-C coal, with the following results:

After Cyclones

Kinetic parameter $k_{I}, \min ^{-1}$

$$
\text { TP-034-2 }
$$

TP-035-1

Rinetic parameter $k_{I I}$, min ${ }^{-1}$

$7.4 \times 10^{-11}$

$6.5 \times 10-11$

Kinetic parameter kIII, min ${ }^{-1}$

$2.0 \times 10^{-5}$

$4.5 \times 10^{-5}$

Kinetic parameter $k_{T}$, min

$2.5 \times 10^{-6}$

$8.5 \times 10^{-5}$

$2.3 \times 10^{-5}$

$4.6 \times 10^{-5}$

Kinetic parameter alpha

1.40

1.40

Coal type (source of char)

Wyoming sub-C

Carbon content of coal, Y

0.725

0.725

Relative reactivity of coal $f_{L}{ }^{0}$

1.24

1.24

Char preparation temp. $\mathrm{T}_{\mathrm{p}}, \mathrm{K}$.

1273

1.122.

Relative reactivity of char, $f_{L}$

0.48

0.81

Overall rate at various conversions, min ${ }^{-1}$

$$
\begin{array}{lll}
X=0.0 & 8.7 \times 10^{-6} & 3.8 \times 10^{-5} \\
0.2 & 7.1 \times 10^{-6} & 3.1 \times 10^{-5} \\
0.4 & 5.0 \times 10^{-6} & 2.2 \times 10^{-5} \\
0.6 & 2.8 \times 10^{-6} & 1.2 \times 10^{-5} \\
0.8 & 1.2 \times 10^{-6} & 5.3 \times 10^{-6}
\end{array}
$$

These rates are insignificant and confirm the conclusions reached from thermodynamics: hypothesis 1 is not viable at the operating conditions used in the RRW PDU. To be viable, the 
temperature of the gas would have to be hotter as further discussed below.

Hotter Normal Gas Stream (Hypothesis 2)

Wyoming Sub-C Coal

At the conditions prevailing prior to quenching in the $K R W$ PDU, the following results are obtained:

Beforc Qucnching

Gas composition:

$\begin{array}{rr}T P-034-2 & T P-035-1 \\ 38.96 & 33.28 \\ 30.82 & 29.27 \\ 15.44 & 22.08 \\ 1.61 & 4.79 \\ 0.55 & 0.37 \\ 12.61 & 10.05\end{array}$

Frecboard tempcraturc, $R$

1273

1108

Kinetic parameter $\mathrm{k}_{\mathrm{I}}$, min ${ }^{-1}$

$1.7 \times 10^{-5} \quad 8.4 \times 10-11$

Kinetic parameter $k_{I I}$, min ${ }^{-1}$

$1.5 \times 10^{-3}$

$2.5 \times 10^{-4}$

Kinctic parameter k $k_{I I}$ min $^{-1}$

$1.5 \times 10^{-3}$

$1.4 \times 10^{-5}$

Kinetic parameter $k_{T}$, min ${ }^{-1}$

$3.1 \times 10^{-3}$

$4.6 \times 10^{-5}$

Rinetic parameter alpha

1.38

1.40

Coal type (source of char)

Wyoming sub-C

Carbon content of coal, Y

0.725

0.725

Relative reactivity of $\cos \mathrm{f}_{\mathrm{L}}{ }^{\circ}$

1.24

1.24 .

Char preparation temp. $T_{p}, R$

1273

1122 
Relative reactivity of char, $f_{L} \quad 1.24 \quad 1.17$

Overall rate at various conversions, min ${ }^{-1}$

$\begin{array}{lll}X=0.0 & 3.8 \times 10^{-3} & 3.1 \times 10^{-4} \\ 0.2 & 3.1 \times 10^{-3} & 2.5 \times 10^{-4} \\ 0.4 & 2.1 \times 10^{-3} & 1.7 \times 10^{-4} \\ 0.6 & 1.2 \times 10^{-3} & 1.0 \times 10^{-4} \\ 0.8 & 5.3 \times 10^{-4} & 4.3 \times 10^{-5}\end{array}$

An important difference between these two tests is the use of quench water to cool the gas leaving the gasifier in test TP-034-2 and the absence of quenching in run TP-035-1.

It is clear from these results that, if the cyclones and membrane filters can be operated at higher temperature, the char will be consumed in-place in the membrane filter although at a slow rate, initially $0.4 \%$ per minute in test TP-34-2, without quenching. Thus operation of a fluidized bed gasifier at the higher end of its temperature range coupled with the reduction or elimination of quenching would tend to ease the fines problem somewhat. Since gains in thermodynamic efficiency can be associated with the elimination of the highly irreversible quenching operation, this approach should be kept in mind. We note that the rate of the steam gasification reaction is negligible in al1 cases compared with the methanation reactions, and that the thermodynamic calculations indicated virtual equilibrium for reaction [III] in the reactor. Partial quenching rather than no quenching at all may yield the most favorable temperature-gas 
composition combination for in-place char gasification, as a compromise between favorable kinetics and favorable equilibrium.

Illinois \#6 Coal

At the same pre-quench gas composition, temperature and pressure but with Illinois \#6 coal instead of Wyoming subbituminous, the following results are calculated:

Coal type Illinoia $\# 6$

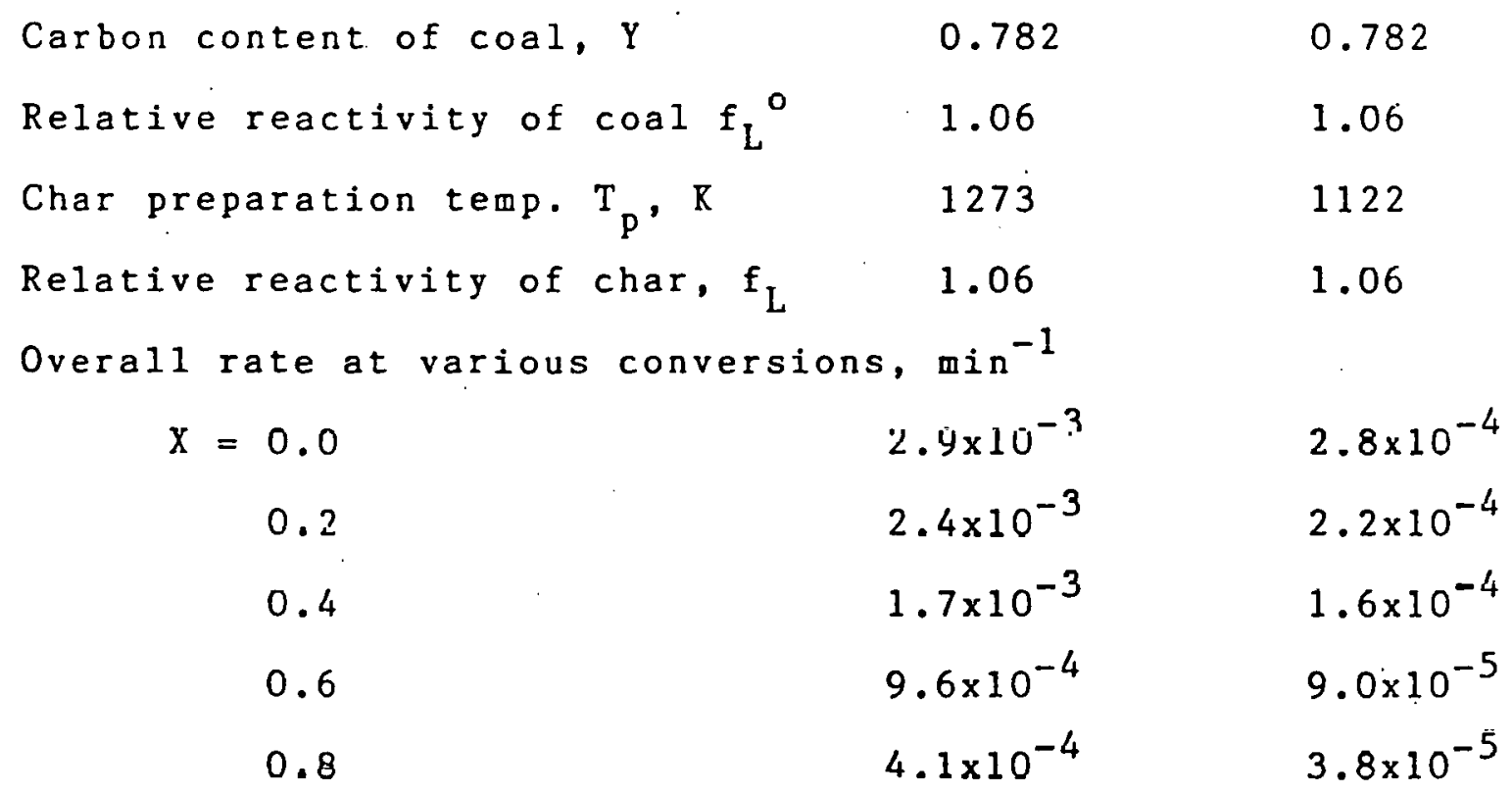

The reaction rate calculated for Illinois \#6.roal is approximately $75 \%$ of the Wyoming subbituminous coal rate. 
Pittsburgh Coal

At the same pre-quench gas composition, temperature and pressure but with Pittsburgh coal, the following results are calculated:

Coal type

Pittsburgh

$\begin{array}{lll}\text { Carbon content of coal, } \mathrm{Y} & 0.842 & 0.842 \\ \text { Relative reactivity of coal } \mathrm{f}_{\mathrm{L}} & 0.825 & 0.825 \\ \text { Char preparation temp. } \mathrm{T}_{\mathrm{p}}, \mathrm{K} & 1273 & 1122 \\ \text { Relative reactivity of char, } \mathrm{f}_{\mathrm{L}} & 0.825 & 0.825\end{array}$

Overall rate at various conversions, min ${ }^{-1}$
$X=0.0$
$2.3 \times 10^{-3}$
$2.2 \times 10^{-4}$
0.2
$1.9 \times 10^{-3}$
$1.8 \times 10^{-4}$
0.4
$1.3 \times 10^{-3}$
1. $2 \times 10^{-4}$
0.6
$7.5 \times 10^{-4}$
$7.0 \times 10^{-5}$
0.8
$3.2 \times 10^{-4}$
$3.0 \times 10^{-5}$

The reaction rate calculated for Pittsburgh seam coal is about $60 \%$ of the Wyoming coal rate.

On this basis, the rates for the lilinois and Pittsburgh coals differ significantly but not drastically from those of the Wyoming coal and the same conclusions would generally apply. It must be pointed out however that the experimental data, such as temperatures and gas compositions on which these calculations are based, were obtained with Wyoming coals. 
Normal Gas Stream plus Catalyst (Hypothesis 3)

The required amount of catalyst could be dissolved or slurrled in the quench water or 1 t could be injected with a separate water spray after the cyclones to boost the char reaction rate at post-quench conditions. The cholce of the location of the catalyst injection would depend on the behavior of the catalyst particles in the cyclone as well as other process considerations. The evaporation of the quench water spray would result in finely divided catalyst solids that would mlx with the finco. This method is suggested as a possibility because it is a practical rather than the most effective mode of application; additional studies are required to establish its efficacy. Perlmutter studied methods of applying the catalysts to the char and concluded that "the wet impregnation method is preferred over ballmilling or bulk mixing because it provides better catalyst-particle contact". However, based on Perlmutter's own discussion in the same report (refer to section 2.2.3) one would have to conclude that the advantage of impregnation must be marginal. Perlmutter's impregnation method consisted in circulating the catalyst solution for one hour over the char, and then vacuun drying. Such an approach is not feasible in a commercial plant, and an important area for research is the determination of the effectiveness of injectluy catalyot with the quench water or ahead of the membrane filter, and of other means of impregnating the char with catalyst. 
The work of McCoy et al. (1983) gielded the following results with Illinois \#6 coal char catalyzed by $\mathrm{R}_{2} \mathrm{CO}_{3}$ ( $\mathrm{R} / \mathrm{C}$ atomic ratio $=0.4$ ):

\section{$\mathrm{CO}_{2}$ Gasification Rate of Illinois \#6 Char}

Temperature, ${ }^{\circ} \mathrm{C}$

Pressure, atm

Uncatalyzed rate, $\min ^{-1}$

Catalyzed rate, $\min ^{-1}$

Ratio cat/unc rates

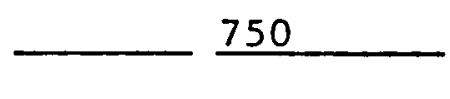

$1 \quad 18 \quad 35$

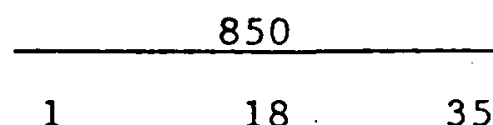

$.003 \quad .006 \quad .006$

.0008

.0018

.0035

.013

.023

\section{Steam Gasification Rate of Illinois \#6 Char}

Temperature, ${ }^{\circ} \mathrm{C}$

Pressure, atm

Uncatalyzed rate, min -1

Catalyzed rate, min ${ }^{-1}$

Ratio cat/unc
750

18

.003

.025

8
850

18

.050

2.5

$\mathrm{H}_{2}$ Gasification Rate of Illinois \#6 Char

Pressure, atm 3 11 35

Uncatalyzed rate, min $^{-1}$

Catalyzed rate, $\min ^{-1}$ Ratio cat/unc rates .0015

$\begin{array}{ccccc}.0003 & .0015 & .0015 & .0035 \\ & .0010 & .0011 & .0040 & \\ & 1 & 2.7 & \end{array}$

Data on the uncatalyzed and catalyzed gasification rates of chars derived from lignite, Illinois \#6 coal, Pittsburgh seam coal, and anthracite, were determined by Kosky et al. (1982), with 
the following results:

$\mathrm{CO}_{2}$ (1 atm) Gasification Rate of N.D. Lignite A Char Temperature, ${ }^{\circ} \mathrm{C}$ $600^{\circ}$ 700 800

Uncatalyzed rate, min $^{-1}$

$$
3.3 \times 10^{-5}
$$

$6.2 \times 10^{-4}$

0.0068

w. $5 \% \mathrm{R}_{2} \mathrm{CO}_{3}$, min

$7.2 \times 10^{-5}$

0.0014 0.016

Ratio cat/unc rates 2.2 2.3 2.4

w. $10 \% \mathrm{~K}_{2} \mathrm{CO}_{3}$, min $1.3 \times 10^{-4}$

0.0021 0.020

Ratio cat/unc rates 3.9 3.7 2.9

w. $20 \pi \mathrm{K}_{2} \mathrm{CO}_{3}$, m1 $\mathrm{n}^{-1}$

$1.7 \times 10^{-4}$

0.0028 0.027

Ratio cat/unc. rates

5.2

4.5 4.0

$\mathrm{CO}_{2}$ ( 1 atm) Gasification Rate of Illinois \#6 Char

Temperature, ${ }^{\circ} \mathrm{C}$ 700

800 900

Uncatalyzed rate, min $=1$

$$
1.7 \times 10^{-5}
$$

$1.7 \times 10^{-4}$

0.0011

w. $5 \% \mathrm{~K}_{2} \mathrm{CO}_{3}, \mathrm{~min}^{-1}$

$2.0 \times 10^{-4}$

0.0022

0.017

Ratio cat/unc rates

12

13

15

w. $10 \% \mathrm{~K}_{2} \mathrm{CO}_{3}, \mathrm{~min}^{-1}$

0.0023

0.019

0.110

Ratio cat/unc rates

135

112

100

w. $20 \% \mathrm{~K}_{2} \mathrm{CO}_{3}, \mathrm{~min}^{-1}$

0.0036

0.028

0.151

Ratio rot/unc rates

212

165

137

$\mathrm{CO}_{2}$ ( 1 atm) Gasification Rate of Pittsburgh Char

Temperature, ${ }^{\circ} \mathrm{C} \quad 700$

Uncatalyzed rate, $\min ^{-1}$

w. $5 \% \mathrm{R}_{2} \mathrm{CO}_{3}, \mathrm{~min}^{-1}$

Ratio cat/unc rates

$$
9.0 \times 10^{-6}
$$

$9.3 \times 10-5$

10
800

$7.0 \times 10^{-5}$

0.0010

14
900

$3.9 \times 1.0^{-4}$

0.0080

21 
The data show the large improvement obtained with Illinois and Pittsburgh coals by the addition of the $\mathrm{R}_{2} \mathrm{CO}_{3}$ catalyst. The improvement is less with lignite, possibly because the ash in the lignite acts as a catalyst and/or because of the higher relative reactivity of uncatalyzed lignite. Rosky et al. added the catalyst prior to coal carbonization in some of their experiments, and after carbonization in others. The gasification runs with post-carbonization catalyst addition gielded significantly slower rates than the gasification runs with the pre-carbonization catalyst addition, indicating the sensitivity of the rate to the method of catalyst impregnation and distribution. The crucial question then is the ability to develop an effective method of catalyst impregnation of the char.

In some applications, such as those involving gas turbines, the presence of alkali metals in the gas is very objectionable. Kosky reports that $\mathrm{K}_{2} \mathrm{CO}_{3}$ began to lose weight at about $950^{\circ} \mathrm{C}$ as a result of dissociation of the salt to $\mathrm{K}_{2} \mathrm{O}$ and $\mathrm{CO}_{2}$, the dissociation being suppressed, as expected, in a $\mathrm{CO}_{2}$ atmosphere. Thus, the temperature would have to be kept below $950^{\circ} \mathrm{C}$ with a reasonable safety margin. From the point of view of decomposition, injection into the colder stream after the cyclones would be preferable to injection with the quench water into a very hot stream.

McCoy also studied the catalytic effect of $\mathrm{CaO}$, with the following results $(\mathrm{Ca} / \mathrm{C}$ atomic ratio $=0.024)$ : 
$\mathrm{CO}_{2}$ Gasification Rate of Illinois \#6 Char

Temperature, ${ }^{\circ} \mathrm{C}$
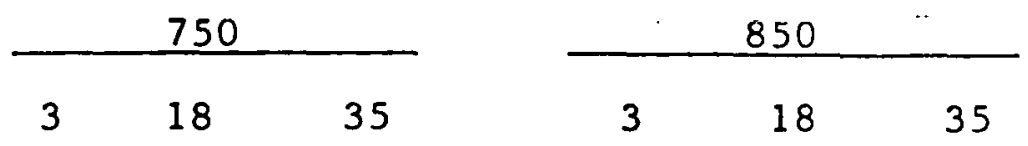

Pressure, atm

.0003

w. $\mathrm{CaO}$, min ${ }^{-1}$

$.003 \cdot .003 \quad .0011$

$.0008 \quad .0018 \quad .0035$
.012

Ratio cat/unc rates

4

7

Steam Gasification Rate of Illinois \#6 Char

Temperature, ${ }^{\circ} \mathrm{C}$ 750

850

Pressure, atm

18

18

Uncatalyzed rate, $\mathrm{min}^{-1}$

.003

.020

w. $\mathrm{CaO}, \mathrm{min}^{-1}$

.020

.040

Ratio cat/unc rates

$\mathrm{H}_{2}$ Gasification Rate of Illinois \#6 Char

Temperacure, ${ }^{\circ} \mathrm{C}$

Pressure, atm

Uncatalyzed rate, $\min ^{-1}$

w. $\mathrm{CaO}, \min ^{-1}$

Ratio cat/unc rates

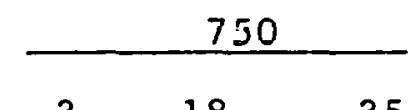

$\begin{array}{lll}3 & 18 & 35\end{array}$

.0015

$.001 \quad .0003 \quad .0005$

0.3

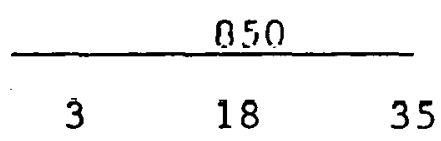

$.0015 \quad .0035$

.0015

1

Lime is an active catalyst for $\mathrm{CO}_{2}$ and steam gasification, but poor for hydrogen gasification, and in the latter case it deactivates rapidly. Thus while CaO is a less attractive calalysl than $\mathrm{K}_{2} \mathrm{CO}_{3}$, it could be considered in cases where alkali metals: are a problem and where the temperature is high enough to indicate: that they would indeed be a problem. 
In summary, catalyst injection is a potentialig attractive possibility for gasification of some of the char on the filter by the normal process gas stream flowing through the membrane.filter. Research is needed to find a practical way of spreading the catalyst on the fines.

Hotter Normal Gas plus Catalyst (Hypothesis 4)

Another approach is a reduction in the amount of quench water to achieve hotter gas temperatures, while injecting dissolved catalyst with the quench water. With this approach, it may be possible to keep the cyclone and filter operating temperatures well below $1000{ }^{\circ} \mathrm{C}$ and get achieve practical in-place gasification rates in the membrane filter.

The joint use of catalyst and temperature control to attain optimum char gasification is primarily a matter of process optimization, and depends on the demonstration of the successful impregnation of the char by the catalyst. 
4.1.1.2 Fixed Bed Processes

\subsection{As-is Normal Gas Stream \\ (Hypothesis 1)}

The report by Pater et al. (1984) provides process flow diagrams and -operating data on the METC fixed-bed gasifier and full-flow cleanup system. Because of the large amounts of tar present in the product gas leaving fixed bed gasifiers, coolers, scrubbers and tar separators follow the cyclone befule final

filtration in a membrane filter or electrostatic precipitator. The cooling required to condense the tars reduces the temperature of the gas stream to a level that is too low for char gasification by the product gas at a meaningful rate. Hence hypothesized approach 1 is not appropriate for fixed bed gasifiers with conventional flow sheets. The insertion of a membrane filter prior to cooling and tar removal is considered impractical, as the presence of tars could result in plugging of the membranes and uther operating problems.

In the hot gas cleanup mode, the gasifier exit gas is not quenched. Sulfur, particulate watter, etc. ara removed from the gasifier exit gas at approximately the gasifier exit temperature $\left(500-650^{\circ} \mathrm{C}\right)$. Clean hot gas then flows to, e.g. a gas luibine. combustor, for combustion and subsequent expansion in a gas. turbine expander to produce power. Maintaining the temperature the gasifier exit gas sufficiently high to prevent tar 
condensation in the hot gas cleanup train is an obvious problem. However, the problem is outside the scope of this report.

Some gasification of char on filters will occur as the char Is exposed to the as-is normal gas stream. However, the gasification rate would be so slow in the 500 to $650{ }^{\circ} \mathrm{C}$ temperature range that inordinately long residence times would be required to obtain a significant degree of char gasification. Thus hypothesị 1 is clearly impractical.

\subsection{Hotter Normal Gas Stream (Hypothesis 2)}

For the cold gas cleanup approach, this method is technically feasible. By providing heat exchangers and direct-fired heaters, the product gas could be heated to a temperature at which it reacts with the carbon in the char. The capital investment and operating costs involved would be large and disproportionate with the benefits achieved by gasifying the char. The most serious drawback of this approach is the need to heat the entire product gas stream by over $500^{\circ} \mathrm{C}$. Other more economical approaches can undoubtedly be found.

For the hot gas cleanup approach, direct fired heaters could be used to increase the gas stream temperature from its exit temperature rango of 500 to $650^{\circ} \mathrm{C}$ to the range of 900 to $1000^{\circ} \mathrm{C}$, which is more promising for rapid gasification. Another approach would be injection of a small amount of oxidant (e.g. air) into 
the gasifier exit gas in order to increase its temperature by partial combustion. [ The authors have doubts about the safety aspects of the latter approach.J If the partial combustion temperature exceeds approximately $1200^{\circ} \mathrm{C}$, the char will essentially be destroyed if the gas stream is at a pressure greater than 10 atm. (See subsequent discussion on entrained gasifiers.) However, a quench immediately downstream of the partial combustor will be necessary to reduce the gas temperature to less than approximately $950^{\circ} \mathrm{C}$ in order to protect metal structuled parto $\varepsilon$ uch as beams and support plates within the membrane filter vessel(s), combustor control valves, etc. If the partial combustor exit temperature is approximately $950^{\circ} \mathrm{C}$, some char will be destroyed in the combustor, but additional residence time on the filter will be required for substantial char gasification. The added complexity, lowered thermal efficiency, and safety consldelations of this approach are likely to rule it out.

\subsection{Normal Gas Stream plus Catalyst} (Hypothesis 3 )

In the METC fixed bed gasifier operating in the cold gas cleanup mode, the producl gas atreaū lenves the Venturi scrubber and enters the electrostatic precipitator at approximate $1 \mathrm{y} \quad 1: 24^{\circ} \mathrm{C}$ on the hasis of the data of Pater et al. (1984). Even the best catalyst does not gasify carbon at this temperature. In the.hot 
gas cleanup mode, use of catalysts will increase the char gasification rate, but not by an amount sufficient to be practical.

4.1.1.2.4 Hotter Normal Gas Stream plus Catalyst (Hypothesis 4)

In the cold.gas cleanup mode, the temperature of the gas stream after tar removal is so low that even with a catalyst (e.g. $124^{\circ} \mathrm{C}$ for the METC fixed bed gasifier), the product gas stream would have to be heated several hundred degrees $C$ to obtain achieve carbon gasification. This approach is not economically attractive.

However, in the hot gas cleanup mode, this approach could be attractive.

The last four sections, dealing with fixed bed gasifiers, may. be summarized by stating that char gasification by the normal gas stream does not seem feasible with those fixed bed processes that lower the gas temperature prior to the membrane filter to remove tars. However, in the hot gas cleanup mode, additional heating of the raw gas, with or without catalyst addition, may be attractive. 


\subsubsection{Entrained Gasification Processes}

Modern entrained gasification processes are guccessful in gasifying almost $100 \%$ of the carbon of many coals by operating at very high temperatures and at elevated pressures. For this reason, the accumulation of char on filters downstream from entrained gasifiers is considered less of a problem thä in the case of fluidized or fixed bed processes. On the other.hand, entrained gasifiers have short residence times, and carbon conversion does vary with the reactivity of the feedstock. This became very clear to one of the authors (Hess) during entrained gasification tests on Rentucky coal char from the FMC COED process and on petroleum coke in a Roppers-Totzek gasifier. The coke had to be ground several times to achieve a particle size at which most of it would react, even though the gasifier operated at a temperature over $1600^{\circ} \mathrm{C}$. This particular gasifier operated at àtospheric pressure, whereas more modern units operate at elevated pressures and would generally benefit from higher rates.

By and large, the in-place gasification of char in a membrane filter in an entrained gasification process would tend to parallel the situation encountered in fluidized bed processes. In both instances the gas is cooled after leaving the reactor to a temperature compatible with the cyclones and clean up train. Thus the question in both processes is to determine the temperature:at which gasification of the char in the filter is feasible with the normal product gas, what opportunities exist to operate the: 
cjclones at a higher temperature, and how effective the injection of catalyst ahead of the filter, or into the filter, can be.

It is known that higher gasification temperatures and longer residence times decrease char reactivity. In the case of entrained gasifiers, the two effects are offsetting, so that it is not clear to what extent reactivity may be affected. It is probable that entrained gasifier chars will be somewhat more refractory to gasification than fluidized bed chars.

\subsubsection{Gasification by a Other Than Normal Gas Stream}

The introduction of a separate gas stream to perform the in-place char gasification in the membrane filter requires the installation of at least one spare filter and of the necessary piping and valves, so that each membrane filter can be taken off-stream periodically for char gasification. This approach would be least objectionable in a large plant involving several filters operating in parallel, so that the provision of one additional filter would not be excessively costly. Since the gasification is done by a separate stream, there is much more freedom to choose the temperature, pressure and composition of that stream and the gasification process in which the char was produced becomes almost immaterial. The discussion that follows therefore applies to any type of gasification process, be it fluidized bed, fixed bed or entrained. 


\subsubsection{1 $\mathrm{CO}_{2}$ Gasification}

(Hypothesis 5)

This approach might be viable in a large gasification plant with several parallel membrane filters. For char gasification by $\mathrm{CO}_{2}$, Johnson (in Elliott's 2nd. Supplement to the Chemistry of Coal Utilization) provides a rate equation for gasification by a $\mathrm{CO}_{2}$-CO mixture as equation 23.119. It is a Langmuir-llinshelwood type equation with reverse reaction:

$$
\text { rate }=\left[k_{5} \mathrm{p}_{\mathrm{CO}_{2}}\left(1-\mathrm{k}_{56} \mathrm{p}_{\mathrm{CO}}{ }^{2} / \mathrm{p}_{\mathrm{CO}_{2}}\right)\right] /\left[1+\mathrm{k}^{\prime} \mathrm{p}_{\mathrm{CO}}+\mathrm{k}^{\prime \prime} \mathrm{p}_{\mathrm{CO}_{2}}\right]
$$

Johnson provides kinetic parameter values for a number of

materials, but a complete set of parameters is provided only for one material, char made from a high volatile Pittsburgh seam coal. For this char, the following gasification rates are calculated:

\begin{tabular}{|c|c|c|c|c|c|}
\hline \multicolumn{2}{|c|}{ Temperature, ${ }^{\circ} \mathrm{C}$} & 740 & 800 & 900 & $10 n$ \\
\hline \multicolumn{2}{|c|}{ Gas Compositinn } & \multicolumn{4}{|c|}{ Gasification rate, $\min ^{-1}$} \\
\hline$\% \mathrm{CO}_{2}$ & $\% \mathrm{CO}$ & & $P=$ & $\operatorname{tm}$ & \\
\hline 100 & 0 & $3.2 \times 10^{-4}$ & 0.0018 & 0.0159 & 0.069 \\
\hline 90 & 10 & $2.8 \times 10^{-4}$ & 0.0013 & 0.0071 & 0.019 \\
\hline 80 & 20 & $2.4 \times 10^{-4}$ & $9.9 \times 10^{-4}$ & 0.0042 & 0.010 \\
\hline 50 & 50 & $8.6 \times 10^{-5}$ & $3.7 \times 10^{-4}$ & 0.0013 & 0.0027 \\
\hline
\end{tabular}


Temperature, ${ }^{\circ} \mathrm{C}$

Gas Composition
740

800

900

1000
Gasification rate, $\min ^{-1}$

$$
P=10 \mathrm{~atm}
$$

$\begin{array}{crcccc}100 & 0 & 3.4 \times 10^{-4} & 0.0020 & 0.0241 & 0.163 \\ 90 & 10 & 2.9 \times 10^{-4} & 0.0014 & 0.0085 & 0.023 \\ 80 & 20 & 2.1 \times 10^{-4} & 0.0010 & 0.0046 & 0.011 \\ 50 & 50 & 2.0 \times 10^{-4} & 1.3 \times 10^{-4} & 0.0012 & 0.0028 \\ & & & P=20 \mathrm{~atm} & \end{array}$

100$$
3.4 \times 10^{-4}
$$$$
0.0020
$$

0.0258

0.196

$90 \quad 10$

$$
2.7 \times 10^{-4}
$$

0.0014

0.0087

0.023

80

20

$1.5 \times 10^{-4}$

0.00095

0.0047

0.011

50

50

$5.6 \times 10^{-4}$

$2.0 \times 10^{-4}$

$9.9 \times 10^{-4}$

0.0027

$$
P=30 \mathrm{~atm}
$$

100

$$
0
$$

$$
3.4 \times 10^{-4}
$$

0.0020

0.0264

0.211

90

10

$2.6 \times 10^{-4}$

0.0014

0.0087

0.023

80

20

$$
9.0 \times 10^{-5}
$$

0.00087

0.0046

0.011

50

50

$5.4 \times 10^{-4}$

$8.0 \times 10^{-4}$

0.0026

The Table shows the strong rate-retarding effect of $C O$ and the large effect of temperature in boosting the rate. Pressure is seen to increase the rate, but the effect levels off as the pressure is increased. Pittsburgh seam coal char is one of the least reactive chars, so that the rates would be more favorable with many other coal chars.

At $1000^{\circ} \mathrm{C}$ and 10 atm., or greater, complete gasification takes place in approximately 5 minutes in pure $\mathrm{CO}_{2}$, but in the presence of $\mathrm{CO}$, the rate is much slower; about 45 minutes at $10 \%$ 
CO. $\mathrm{CO}_{2}$ gasification of char is feasible, but not very attractive because of the adverse effect of CO, unless a nearly pure $\mathrm{CO}_{2}$ stream were available. .

\subsubsection{Steam Gasification}

(Hypothesis 6)

Schmidt et al. (1983) performed experiments on the gasification of Wyoming Sub-C coal at $1800^{\circ} \mathrm{F}\left(982^{\circ} \mathrm{C}\right)$ and 1 atm. in a mixture made up of $33 \% \mathrm{H}_{2} \mathrm{O}, 17 \% \mathrm{H}_{2}$ and $50 \% \mathrm{~N}_{2}$. The chars were prepared in the laboratories at various heat treatment temperatures (HTT). The times required to reach $50 \%$ and $80 \%$ gasification of the char may be summarized as follows:

$$
\text { Wyoming Sub-C Coal Char }
$$

$\mathrm{HTT},{ }^{\circ} \mathrm{C} \rightarrow-\rightarrow$

TIUL LU \& LUCh:

$$
\begin{aligned}
& 50 \% \text { conversion, min } \\
& 80 \% \text { conversion, min }
\end{aligned}
$$

982 1083

1200

Cusifleuldun Limé uL $982^{\circ} \mathrm{C}$

1.3

1.4

1.8

3.2

2.4

2.5

3.8

Chars fines collected in the RRW PDU primary cyclone with Wyoming Sub-C coal feedstock had reactivity of $93 \%$ of the sample prepared at $982^{\circ} \mathrm{C}$ HTT. The times to reach $50 \%$ and $80 \%$ conversion with these fines are therefore estimated at 2.0 and 3.5 minutes respectively when gasified in the above-mentioned $\mathrm{H}_{2} \mathrm{O}-\mathrm{H}_{2}-\mathrm{N}_{2}$ mixture at $982^{\circ} \mathrm{C}$. 
The summary of Schmidt et al. data above Indicates an optimum temperature for HTT in the range of $1100^{\circ} \mathrm{C}$. Clearly, for this very reactive Wyoming Sub-C coal char, steam gasification is very feasible. Based on the general correlation of Johnson, discussed In section 4.1 .1 .2 , the reactivities of Illinols \#6 and of Pittsburgh seam coal chars are related to that of Wyoming subbituminous coal char as follows:

Coal

Wroming Sub-C

Illinois \#6

Pittsburgh
Relative reactivity

1.24

1.06

0.82
Normalized

1.00

0.85

0.66

These figures may underestimate the rate variation between chars prepared from different coals. Katta and Keairns (1981) used a coke breeze that contained $97.3 \%$ C. On the basis of Johnson's correlation, it should have a relative reactivity of 0.169 , which, if referred to Wyoming $S u b-C$ as 1.00 , would be normalized to 0.136 . On that basis, Wyoming Sub-C should be 7.34 times as reactive as coke breeze, get Schmidt et al. report a factor of about 150. On the other hand, Johnson recomends his correlation only up to a carbon content of $93 \%$, and the problem may lie in the extrapolation of Johnson's equation to $97 \%$ rather than in the equation itself. One may conclude that the estimates of the gasification reactivity of Illinois \#6 and especially of Pittsburgh seam coal may be on the optimistic side. By combining the gasification times measured by Schmidt et al. for Wyoming coal char and the relative reactivities calculated from Johnson's 
correlation, the following gasification times are estimated:

Ilinois \#6 Coal Char Fines

$\begin{array}{lcccc}\text { HTT, }{ }^{\circ} \mathrm{C}--\rightarrow> & 982 & 1083 & 1200 & 1300 \\ \text { Time to reach: } & & \text { Gasification times at } 982{ }^{\circ} \mathrm{C} & \\ 50 \% \text { conversion, min } & 2.1 & 1.5 & 1.6 & 2.1 \\ 80 \% \text { conversion, min } & 3.8 & 2.8 & 2.9 & 4.5\end{array}$

Pittsburgh Seam Coal Char Fines

HTT, ${ }^{\circ} \mathrm{C}=--\rightarrow$ 982

$1083 \quad 1200$

1300

I1 ine to reach:

Gasification times at $982^{\circ} \mathrm{C}$

$\begin{array}{lllll}50 \% \text { conversion, } \min & 2.7 & 2.0 & 2.1 & 2.7 \\ 80 \% \text { conversion, min } & 4.8 & 3.6 & 3.8 & 5.8\end{array}$

The calculated rates for coke breeze, based on Katta and Keairns' Ergun type rate equations are as follows:

Coke Breeze Gasification at $982^{n} \mathrm{C}$

$\mathrm{P}_{\mathrm{H}_{2}} / \mathrm{P}_{\mathrm{H}_{2}} \mathrm{O}$

$\begin{array}{cccc}0 & .1 & .2 & .5 \\ 0.020 & 0.0095 & 0.0062 & 0.0030 \\ 25 & 53 & 81 & 167\end{array}$

Time to $50 \%$ conv., min

The above data show that, as in the case of $\mathrm{CO}$, increasing the partial pressure of hydrogen causes a considerable slowdown in the reaction rate. At a ratio of $\mathrm{p}_{\mathrm{H}_{2}} / \mathrm{p}_{\mathrm{H}_{2}} \mathrm{O}$ of 0.5 the reported value for Wyoming Sub-C was 1.8 min, for a ratio between coke breeze and Wyoming Sub-C of 93 , as opposed to the calculated. ratio of 7.4 calculated from Johnson's correlation. 
Katta and Reairns found that, over the temperature range from 950 to $1040^{\circ} \mathrm{C}$, the rate of the steam gasification reaction was 2.5 to 5 times faster than that of the carbon dioxide reaction. Thus the steall gasification reaction appears to be the better choice. The data presented for the Wroming subbituminous coal char indicate that only a few minutes are needed for gasification. The required times for Ilinois \#6 and Pittsburgh seam coal chars calculated from Johnson's correlation are also verp favorable, but In view of the uncertainty surrounding Johnson's correlation, substantially longer times may be required to gasify char fines from these coals. However this can be compensated for by keeping the hydrogen/steam ratio low, as demonstrated by the coke breeze calculations.

It is concluded that in-place steam gasification of char is feasible, and may be economical in plants where several filters in parallel, including a spare, is feasible.

\subsubsection{Steam injection into Normal Gas Stream (Hypothesis 7)}

To avold the need of a spare filter together with extra valving, the composition of the product gas could be modified by injection of additional steam to make the gas composition more favorable to char gasification. In general, this would require excessive amounts of steam and would therefore be uneconomical. It is however technicaliy feasible and could be used under some 
special circumstances, for example if rapid gasification of the char could be achieved by injecting steam over part of the cycle only. In general this would be feasible only with very reactive chars, in which case steam injection should not be required.

\subsubsection{In-Place Combustion \\ (Hypothesis 8 )}

Combustion is basically attractive when compared with gasification because it is so much more rapid. Perlmutter's extensive study provides extensive information on the combustiun of chars from various coals. The information in Table 10 lists the critical temperature of various coal chars. (The critical temperature is defined as the temperature at which the rate of weight loss is $0.11 \mathrm{~min}^{-1}$.) All the temperatures listed in that table are below $600^{\circ} \mathrm{C}$ for combustion in air. Thus this approach is thermodynamically and kinetically feasible. Since the rate is rapid, there would be no problems relating to the required equipment volume, or to the time required to perform the operation. However, serious plant safety problems need to be addressed and solved with this approach, both in design and nperation. The approach could be used in the case of several parallel filters, each of which would he regenerated in turn at the proper time. Adequate precautions for purging the filters so as to avoid the mixing of air with the product gas would have to be taken. 


\title{
4.1.2.4 Catalyzed In-Place Combustion (Hypothesis 9)
}

\begin{abstract}
Because of the low temperature and the rapid rate at which char combustion takes place, there is little incentive to attempt to speed up the reaction further by the addition of catalyst. Indeed, the injection of catalyst would only further complicate the operation, which would be a complex and difficult one, as described in the preceding paragraph.
\end{abstract}

\subsection{INCREASED CHAR RESIDENCE TIME IN THE FILTER (Hypothesis 10)}

Membrane filters are designed to provide the necessary filtration area at the available pressure drop and to provide the volumetric capacity for storing the solid between discharges. If necessary, the frequency at which the solids are discharged can often be adjusted to maintain the operation within the volumetric and pressure drop design parameters. If the filter is also to be used as a char gasifier to simplify the char disposal problem, then an additional design factor must be addressed: the availability of sufficient residence time for gasification. In our discussion thus far, we have aosumed that the membrane filter exists and we have attempted to determine if there is sufficient

$$
-105-
$$


time to gasify a substantial portion of the char. Here we are looking at the problem from a different perspective: how to design a filter that will ensure gasification of the desired fraction of the char. In some instances, the size of the dual-function filter-char gasifier may increase somewhat over the size that would be selected for a single purpose filter.

This is the proper approach, unless one is retrofitting, and a detailed economic study must be made in each case to determine the optimum filter size and the optimum percentage of char to be gasified in-place.

4.3 REMOVAL OF CHAR FROM FILTER FOLLOWED BY CHAR PROCESSING (Hypothesis 11)

This method is a borderline case, because in some ways it fails to meet the criteria of this pruject. It doos not reduce the amount of char that has to be haudled by the filters. Thus it competes with other methods of char disposal. Gasification in a separate unit or combustion are possible alternatives. The net amount of enelyy recovarod is likely to be small and economically insignificant after the processing costs, the main advantage being the elimination of a nuisance. This being the case, the simplest process is likely to be also the most economical. In this instance, combustion is likely to be preferable to gasification because of ils lower cost. However the feasibility of combustion... 
will depend on the amount of ash and the amount of sulfur and other objectionable components in the ash. If emission problems would preclude combustion, then gasification would have to be considered. A separate gas cleanup would undoubtediy be uneconomical, and some was would have to be found to recycle the resulting gas and take advantage of existing cleanup facilities. As we get into the details of this operation, it becomes clear that this is basically a complex way of getting rid of a simple problem, with many new problems to be solved. The solution to these problems is likely to be costly. Except in unusual circumstances (e.g. with very low sulfur coals), this approach seems less desirable than some of the other hypothesized methods. 


\section{CONCLUSIONS}

1. The preferred method of reducing the amount of char fines captured in membrane filters is to gasify the char in-place by reaction with components of the gas stream normally flowing through the filter. This method is preferred because it is simple, economical, and requires only minimal process changes.

2. The preferred method of the preceding paragraph is applicable to processes utilizing flululzed or cntrained bed gasifiers, but not to those using fixed beds, becouse the relativelg low exit temperature of the fixed bed gasifier exit gas is too low for practical gasification rates.

3. The in-place gasification rate by the preferred method depends on the Lype of cool from which the char was made, the processing conditions to which it was subjected, and on the composition of the product gas. In general, temperatures in the range of $1000^{\circ} \mathrm{C}$ or higher have to be achieved to attain rates capable of gasifying a substantial fraction of the char. Such temperatures require reduction or elimination of quenching at the gasifier outlet.

4. An attractive theoretical alcerulive to the uso of higher temperatures is the injection of solution of a catalyst such as potassium carbonate. This catalyst can increase the rate of the gasification reaction of bituminous and subbituminous coals by an 
order of magnitude and make possible significant, in-place char gasification at temperatures in the 750 to $850^{\circ} \mathrm{C}$ range. However, to be effective, the catalyst must be distributed over the char surface and must be in intimate contact with it so as to create reactive sites on the outside surface of the char. Interstitial catalyst located in between char particles is useless. An effective method to apply the catalyst to the char is needed. Sodium or potassium based catalysts are probably impermissible if there is a possibility of a significant fraction of the catalyst passing through the filter to the combustor.

5. Research to develop an effective and practical method of catalyst application should have first priority in connection with the in-place gasification of char in membrane filters. If this objective can be achieved, it is likely that the char gasification could be carried out at temperatures below those at which potassium appears in the gas phase.

6. Assuming only partial success in the application of catalyst, the combination of catalyst use and somewhat higher than normal temperatures by reduction of the amount of quenching is an attractive alternative.

7. Another feasible approach is gasification by a special gas stream. This method provides greater freedom in tailoring the composition, temperature and pressure of the gas stream to fit the 
char gasification requirements, and would be applicable to all types of gasiflers, even fixed bed ones. It would however involve the operational and economic burden of an extra membrane filter, so that each membrane filter would be off-stream for part of the time. Special valving and piping to rotate filters is very expensive at high temperatures and above atmospheric pressure. This approach would be most economical in gasification plants with several membrane filters in parallel. The reactant gas could be steam, carbon dioxide, hydrogen, or a mixture of these gases. Air seems less desirable because of the safety issues and related operational complexities introduced by the presence of oxygen.

8. A study on the economics of membrane filter operation are desirable to determine the feasibility of the method described in the preceding paragraph.

9. Increased residence time in the melurale filter to achicvo tho desired in-place char gasification is a tool that is available and should be used. Instead of designing the filter solely on the basis of pressure drop and solid volume requirement, a third criterion, char gasification should be considered in the design phase. Final design is based on an economic balance that determines the fraction of char to be gasified.

10. Char processing after removal from the filter is an. option that warrants further study. The choices are 
conventional solid waste disposal, gasification and combustion. Environmental considerations and economics must determine the cholce. Because of its simplicity and favorable economics, combustion will generally be preferable to gasification. However, environmental limitations mag rule out combustion in the case of high sulfur coals. Gasification is expected to be practical after removal from the filter only where very large quantities of fines are involved. 


\section{REFERENCES}

Advanced Development of a Pressurized Ash Agglomerating Fluidized-Bed Coal Gasification System, Morgantown Energy Technology Center, Sept 7, 1983.

Advanced Development of a Pressurized Ash Agglomerating Fluidized-Bed Coal Gasification System, Morgantown Energy Technology Center, July 25, 1984 .

Advanced Development of a Pressurized Ash Agglomerating Fluidized-Bed Coal Gasification System, Morgantown Energy Technology Center, January 31, 1986 .

Bhatia, S.R., Perlmutter, D.D., "A Random Pore Model for Fluid-Solid Reactions: I. Isothermal, Rinetic Control," AlChE Journal, vol. 26, no. 3, May 1980, pp. 379-385.

Bhatia, S.R., Perlmutter, D.D., "A Random pore Model for Fluid-Solid Reactions: IT. Diffusion and Transprot Effects," AlChE Journal, vol. 27, no. 2, March 1981, pp. 247-254.

Blackwood, J.D., McCarthy, D.J. Cullis, B.D., Aust. J. Cham., 1967, 20, Pp. 2525-2528.

Cale, J.M., Genapathi, R., Ellison, S.E., "Transient Rinetic Studies of Char Reactions: Gasification in Steam-Argon Mixtures," ACS Fuel Div., Preprints, Anaheim, CA, 1985, 30, pp. 294-303. 17.

Calvelo. A., Cunningham, R.E., Journal of Catalysis, 1970 ,

Calvelo, A., Smith, J.M., "Intrapellet Transport in Gas-Solid Keactions," Cheluical Procccdings, 1970, $\underline{3}, \mathrm{p} p .1-7$.

Carrazza, J., Somorjai, G.A., Heinemann, H., "Steam Gasification of Carbonaceous Solids Catalyzed by a Mixture of Potassium and Nickel 0xides Below $1000 \mathrm{R}, "$ ACS Division of Fuel Chemicals, vol. 31, no. 3, Preprints, Anahe1m, CA, Sept 7-12, 1986, P . 158-165. 645 .

Chan, E.M., Papic, M.M., Can. J. Chen. Eng., 1976, 54, p.

Chornet, E., Baldasano, J., Hadi, T., "Rinetic Expressions for the Coal Char-Gas Reactions," Fuel, 1979, 58, pp. 395-39.6. 1986.

Coal Gasification, Morgantown Energy Technology Center, Aug 
Curran, G.P., Fink, C.E., Gorin, E., American Chemical Society Fuel Chemical Div., Preprints, vol. 12, no. 3, 1968 , P. $62-82$.

Devanathan, N., Saxena, S.C., "Transport Model for Devolatilization of Large Nonplastic Coal Particles: The Effect of Secondary Reactions," Ind. Eng. Chem. Res., 1987, 26, pp. 539-548.

Dutta, S., Wen, C.Y., Belt, R.J., American Chemical Society Div. Fuel Chem, Preprints, vol. 20, no. 3, 1975, pp. 103-114.

Dutta, S., Wen, C.Y., Belt, R.J., "Reactivity of Coal Char 1. In Carbon Dioxide Atmosphere," Ind. Eng. Chem..Proc. Des. and Dev., 1977, 16, pp. 20-30.

Elliott, M.A., ed., Chemistry of Coal Utilization, Second Supplementary Volume, John Wiley \& Sons, New York, Pp. 1491-1598.

Ergun, S. Bur. Mines Bul1., 1962, 598.

Freund, H., "The Rinetics of Carbon Gasification by $\mathrm{CO}_{2}$," $\mathrm{ACS}$ Preprints, Anaheim, CA, 1985, 30, pp. 311-319.

Fuchs, W., Yavorsky, P.M., presented at Symposium on Structure and Reactivity of Coal and Char, $170 t h$ National Meeting of the American Chemical Society, Chicago, Aug 1975.

Galegher, S.J., et al., Rinetics of Catalyzed Steam Gasification of Low-Rank Coals to Produce Hydrogen, Fossil Energy, Morgantown Energy Technology Center, June 1986.

Ghate, M.R., Jarr, L.A.B., Proceedings of the Sixth Annual Gasification Contractors Meeting, Fossil Energy, Morgantown Energy Technology Center, June 1986.

Ghate, M.R., Lai, H.L., Proceedings of the Fourth Annual Advanced Gasification Contractors Meeting, Fossi1 Energy, Morgantown Energy Technology Center, Nov 1984.

Guzman, G.L., Wolf, E.E., "Rinetics of the $\mathrm{K}_{2} \mathrm{CO}_{3}$-Catalyzed Steam Gasification of Carbon and Coal," Ind. Eng. Process Des. Dev., 1982, 21, Pp. 25-29.

Hamblen, D.G., Serio, M.A., Bert, P.E., "Chemical and Physical Development of Char Particles During Devolatilization," Proceedings of Sixth Annual Gasification Contractors Meeting, edited by Ghate, M.R., Baker Jarr, L.A., Morgantown Energy Technology Center, 1986, Pp. 102-111. 
Heinemann, H., "Catalytic Gasification of Chars or Carbon," Proceedings of Sixth Annual Gasification Contractors Meeting, edited by Ghate, M.R., Baker Jarr, L.A.B., Morgantown Energy Technology Center, 1986, 6043, p. 36 .

Isaacs, L.L., "The Thermodjnamics of Coal Chars; Correlation of Free Energy of Formation with Reactivity," ACS Fuel Chem. Div., Preprints, vol. 23, no. 4, Sept 1978, pp. 215-223.

JANAF Thermochemical Tables, Second Edition, US Dept. of Commerce, Nat. Stand. Ref. Data Ser., Nat. Bur. Stand., 37, 1971. 308 .

Jensen, G.A., Ind. Eng. Chem. Proc. Des. Dev., 1976, 14, p.

Johnson, J.L., "Chemistry of Coal Utilization," Second Supplimentary Volume, edited by Elliot, M.A., Wileg-Interscience, 1982 .

Rasaorka, S., Sakata, Y., Rayano, S., "Rate Expression and Evolution of Various Coal Chars With Steam and Oxygen," Kagaku Kogaku Ronbunshu, 1982, 8, Pp. 51-58.

Ratta, S., Reairns, D.L., "Study of Rinetics of Carbon Gasification Reactions," Reprinted From I\&EC Fundamentals, vol. 20, Feb 1981, pp. 6-13.

Relemen, S.R., Freund, H., "A Comparison of $\mathrm{CO}_{2}$ and $\mathrm{O}_{2}$ Gasification of Giassy Carbon," ACS Fuel Div., Preprints, Anaheim, CA, 1985, 30, pp. 286-293.

Relemen, S.R., Freund, H., Mims, C., "Characterization of Potasium Catalysts Added as KOH to Carbon Surfaces," ACS Fuel Div. Preprints, Anaheim, CA, 1985, 30, pp. 349-359.

Khan, M.R., "Reactivity of Low-Temperature Chars:

Significance of Char Active Surface Areas as a Reactivity

Parameter," ACS Fuel Chem. Div., Preprints, vol. 32, no. 1, April 5-10, 1987, Pp. 298-309.

Koenig, P.C., Squires, R.G., Laurendeau, N.M., "Char Gasification by Carbon Dioxide: Further Evidence for the Two-Site Model," ACS Fuel Div., Preprints, Anahe1m, CA, 1985, 30, pp. $320-329$.

Kosky, P.G., et al., Coal Gasification Cacalysiy Mechan1smE, Morgantown Energy Technology Center, April 1982, pp. 35-36.

Ryotani, T., et a1.. "A TPD Study on $\mathrm{H}_{2} \mathrm{O}-$ Gasified and $0_{3}$-Chemisurbed Coal Chare," ACS Fuel Chem. 2Div., Preprints, .vol: 32 , no. 1, Apr11 5-10, 1987, pp. 279-285. 
Leslie, I.H., "Coal Char Structure and Reactivity," University Microfilms International, Ann Arbor, MI, pp. iv-v, $341-346$.

Levenspiel, 0., "Chemical Reaction Engineering," Wiley, New York, 1967.

Margrave and Hange, Proceedings of Fourth Annual Advanced Gasification Contractors Meeting, edited by Ghate, M.R., Lai, H.L., Morgantown Energy Technology Center, Nov 1984.

Mason, D.M., Gandhi, R.N., "Formulas for Calculation the Calorific Values of Coal and Coal Chars: Development, Tests, and Uses," Fuel Processing Technology, 1983, 7, Pp. 11-22.

McCoy, L.R., et.al., and Goldberg, I.B., et al., Investigation of Coal Gasification Catalysis Reaction Mechanisms, Morgantown Energy Technology Center, Nov 1981.

McCoy, L.R., et.al., and Goldberg, I.B., et al., Investigation of Coal Gasification Catalysis Reaction Mechanisms, Final Report, Morgantown Energy Technology Center, 1983. 644.

Menster, M., Ergun, S., US Bureau of Mines Bulletin, 1973,

Mims, C.A., Pabst, J.K., "Alkall Catalyzed Carbon Gasification: I. Nature of the Catalytic Sites," ACS Fuel Chem. Div., Preprints, vol. 25, no. 3, Aug 24-29, 1980, pp. 258-268.

Muhlen, H.J., Heek, R.H.v., Juntgen, H., "Rinetics of $0_{2}$-Chemisorption on Chars and its Relevance to Char Reactivity," ACS Fuel Chem. Div., Preprints, vol. 32, no. 1, April 5-10, 1987, pp. 286-297.

Pater, R., et.al., Fixed-Bed Gasifier and Cleanup System Engineering Summary Report Through Test Run No. 100, Fossil Energy, Morgantown Energy Technology Center, June 1984.

Perlmutter, D.D., Effects of Inorganics and Pore Structure on Char Gasification Rinetics, Morgantown Energy Technology Center, October 1983 .

Ratcliffe, C.T., "Kinetic and Mechanistic Aspects of $\mathrm{CO}_{2}$ Gasification on Alkali Treated Carbon," ACS Fuel Div., Preprints, Anaheim, CA, 1985, 30, $\mathrm{pr} .330-340$.

Ratcliffe, C.T., Vaughn, S.N., "Population and Turnover of Active Potassium Sites on Bituminous Coals During Gasification," ACS Fuel Div., Preprints, Anaheim, CA, 1985, 30, pp. 304-310. 
Scaron1, A.W., Morgan, B.A., "Reactivity in Alr of Chars Produced From a Lignite Containing Various Cations," ACS Fuel Div., Preprints, Anaheim, CA, 1985, 30, PP. 278-285.

Schmal, M., Monteiro, J.L.F., Castellan, J.L., "Rinetics of Coal Gasification," Ind. Eng. Chem Process Des. Dev., 1982, 21, Pp. 256-266.

Schmidt, D.R., et al., "Advanced Development of a Pressurized Ash Agglomerating Fluidized-Bed Coal Gasification System," Quarterly Program Report, FE-19122-28, Sept 7, 1983.

Schmidt, D.R., et al., "Advanced Development of a Pressurized Ash Agglomerating Fluidized-Bed Coal Gasification System," Quarterly Program Report, FE-19122-38, July 25, 1984.

Schmidt, D.R., et al., "Advanced Development of a Pressurized Ash Agglomerating Fluidized-Bed Coal Gasification System," Quarterly Program Report, FE-19122-49, Jan 31, 1986.

Sears, R.E., et.al., "Catalyzed Steam Gasification of Low-Rank Coals to Produce Hydrogen," ACS Fuel Chem. Div., Preprints, vol. 31, no. 3, Sept. 7-12, 1986, pp. 166-175.

Seery, D.J., Freihaut, J.D., "Investigation of Coal Devolatilization: Rinetics and Product Characterization," United Technologies Research Center, Sept 23, 1981 to Dec 23, 1981.

Simons, G., "The Unified Coal-Char Reaction," Fuel, 1979, 59, p . 143-144.

Stefano, J.M., Evaluation of the WEN II and DENN-1D Steady-State, Fixed-Bed Gasifier Models, Morgantown Energy Technology Center, Mag 1985.

Suluberg, E.M., Calo, J.M., Wojtowicz, M., "Uxygen Chemisorption as a Tool for Characterizing 'Young' Chars," ACS Division of Fuel Chemicals, vol. 31, no. 3, Preprints, Anaheim, CA, Sept 7-12, 1986, pp. 186-193.

Suzuki, T., et. al., "The Catalytic Steam Gäsificatiun uI one Australian and Three Japanese Coals Using Potassium and Sodium Carbonates," Fuel Processing Technology, 1984, 8, pp. 205-212.

Szekely, F., Fivans, J.W., Chem Eng Sci, 1970, 25, p. 1091.

Talwalkar, A.T., A Topical Report on Coal Pyrolysis, Morgantown Energy Technology Center, Febuary 1983.

Taylor, R.W., Bowen, D.W., Lawrence Livermore Lab Report, UCRL 52002, NTIS, 1976. 
Temkin, M.I. Advances in Catalysis, 1978, 28, p. 173.

Ternan, M., Sekhar, M.V.C., "The Catalytic Steam Gasification of Chars from Various Sources by $\mathrm{R}_{2} \mathrm{CO}_{3}$," Fuel Processing Technology, 1985, 10, pp. 77-89.

Vanderbilt University, Dept. of Chem. Eng., "Influence of Changing Particle Structure on the Rate of Gas-Solid Gasification Reactions," DOE/MC/16053-1610, 1984.

Von Fredersdorff, C.G., Inst. Gas Technology Chicago Res. Bul1, $1955, \underline{19}$.

Wen, C.Y., Ind. Eng. Chem. 1968, 60, p. 34 .

Wong, C., Yang, R.T., "Inhibition and Catalysis of the Reaction of Steam on the Basal Plane of Graphite by Potassium Carbonate and Potassium Hydroxide," Ind. Eng. Chem. Fundam., $1984, \underline{23}$, pp. 298-303.

Wood, B.J., et.al., Sodium Chloride as a Catalyst for the Gasification of Coal Char Final Report, Tasks 8 and 9 , Fossil Energy, Morgantown Energy Technology Center, Dec 1985.

Yang, R.Y.K., "Kinetics of High Temperature and Pressure Char-Steam Reactions in Coal Gasification, "Proceedings of Fourth Annual Advanced Gasification Contractors Meeting, edited by Ghate, M.R., Lai, H.L., Morgantown Energy Technology Center, $1985, \underline{2}$, p. 40 . 
